\title{
AVALIAÇÃO DO EFEITO TÓPICO DO \\ ALENDRONATO NA SUPERFÍCIE RADICULAR DE DENTES EXTRAÍDOS E REIMPLAN TADOS. \\ ANÁLISE MICROSCÓPICA EM DENTES DE RATOS
}

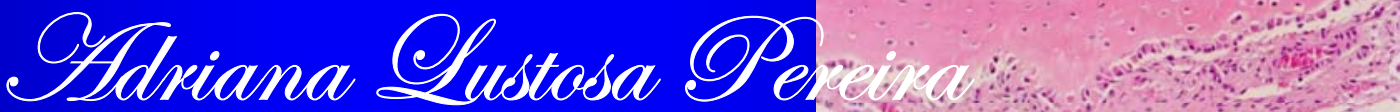

Dissertação apresentada à Faculdade de Odontologia de Bauru, da Universidade de São Paulo, como parte dos requísitos para: obtenção do título de Mestre em Odontologia, área de Endodontia.

(Edição Revisada) 
AVALIAÇÃO DO EFEITO TÓPICO DO

\author{
ALENDRONATO NA SUPERFÍCIE RADICULAR DE \\ DENTES EXTRAÍDOS E REIMPLANTADOS.
}

ANÁLISE MICROSCÓPICA EM DENTES DE RATOS

Ofdriana Qlustosa OPereira

\begin{abstract}
Dissertação apresentada à Faculdade de Odontologia de Bauru, da Universidade de São Paulo, como parte dos requisitos para obtenção do título de Mestre em Odontologia, área de Endodontia.
\end{abstract}

Orientador: Prof. Dr. Roberto Brandão Garcia

(Edição Revisada)

\title{
BAURU
}

2005 


\section{Pereira, Adriana Lustosa}

P414a Avaliação do efeito tópico do alendronato na superfície radicular de dentes extraídos e reimplantados. Análise microscópica em dentes de ratos. / Adriana Lustosa Pereira. -- Bauru, 2005

xviii 89p.: il. ; $30 \mathrm{~cm}$.

Dissertação (Mestrado) -- Faculdade de

Odontologia de Bauru. Universidade de São Paulo.

Orientador: Prof. Dr. Roberto Brandão Garcia

Autorizo, exclusivamente para fins acadêmicos e científicos, a reprodução total ou parcial desta dissertação/tese, por processos fotocopiadores e outros meios eletrônicos.

Assinatura:

Data:

Comissão de Ética no Ensino e Pesquisa em Animais FOB/USP:

$N^{\circ}$ do Protocolo: $24 / 2003$

Data: Projeto de pesquisa aprovado em 06 de agosto de 2003 


\section{Dados Curriculares}

\begin{tabular}{|c|c|}
\hline \multirow[t]{2}{*}{ Nascimento } & 15 de abril de 1972 \\
\hline & Goianésia - GO \\
\hline Filiação & $\begin{array}{l}\text { Divino Apolinário Pereira } \\
\text { Hilda Lustosa Pereira }\end{array}$ \\
\hline 1990-1994 & $\begin{array}{l}\text { Curso de Graduação na Faculdade de } \\
\text { Odontologia - UFG }\end{array}$ \\
\hline 1997-1999 & $\begin{array}{l}\text { Curso de Especialização em Endodontia na } \\
\text { ABO - GO }\end{array}$ \\
\hline $2003-2005$ & $\begin{array}{l}\text { Curso de Pós-Graduação em Odontologia, } \\
\text { área de Endodontia, nível de Mestrado, na } \\
\text { Faculdade de Odontologia de Bauru - USP }\end{array}$ \\
\hline \multirow[t]{3}{*}{ Associações } & $\begin{array}{l}\text { CROGO - Conselho Regional de Odontologia } \\
\text { de Goiás }\end{array}$ \\
\hline & ABOGO - Associação \\
\hline & Odontologia de Goiás \\
\hline
\end{tabular}




\section{Agradecimentos}

\section{A Deus}

Senhor,

Há algo especial no ar, Existe um louvor em meu coração, neste dia... Quero lhe agradecer por seu infinito amor, Por tornar possivel a concretização deste sonho, Pelo dom da vida, pela presença constante, pela vitória! 
Aos meus queridos pais, Hilda e Divino

A vocês, que me deram a vida e me ensinaram a vivê-la com dignidade, não bastaria um obrigado;

A vocês, que iluminaram os caminhos obscuros com afeto e dedicação, para que eu os trilhasse sem medo e cheia de esperança, não bastaria um obrigado;

A vocês que se doaram inteiros e renunciaram aos seus sonhos, para que, muitas vezes, pudessem realizar os meus, não bastaria um obrigado;

A vocês, pais por natureza, por opção e amor, não bastaria dizer que não tenho palauras para agradecer-lhes tudo isso.

Mas é o que acontece agora, quando procuro sofregamente uma forma verbal de exprimir esta emoção ímpar. Uma emoção que palauras dificilmente traduziriam... 
Aos meus queridos irmãos, Alexandre, Ana Cláudia e Lorena, que mesmo à distância, estiveram presentes, torcendo pelo meu êxito, incentivando-me nos momentos difíceis.

Ao meu querido sobrinho, Arthur, meu xodó, cujo sorriso sempre me fortalece. A "tia Adrinha" ama muito você.

À minha cunhada, Dulcenyr e aos meus cunhados, Augusto e João Neto, que sempre torceram pela minha vitória e, na medida do possivel, ajudaram-me.

A toda a minha família, em especial ao meu avô Geraldo e à minha avó Faustina (in memorian), que tantas vezes substituíram meus pais, principalmente durante a minha infância, contribuindo para que me tornasse a pessoa que sou. 
Ao meu orientador, Professor Dr. Roberto Brandäo Garcia

"Uns são homens, alguns são professores, poucos são Mestres. Aos primeiros, escuta-se; aos segundos, respeita-se; aos últimos, segue-se."

(Raquel Eckert)

Pela efetiva orientação durante todo este trabalho,

Pela incansável busca pela perfeição e

Pela ajuda e apoio nos momentos difíceis,

Muito obrigada! 
À minha querida e grande amiga Cristiane, a Cris, por sempre me apoiar nos momentos mais críticos, por não me deixar desistir, pela amizade sincera. Cris, serei eternamente grata a você.

À minha amiga peruana, Mônica, uma das pessoas mais especiais e verdadeiras que conheci, muito obrigada.

Aos meus amigos do Mestrado em Endodontia, Dani, Thaís, Eduardo, Amélio, Luciano, Augusto, Norberto e Járcio, pela amizade, pela troca de experiências e aprendizado durante todo o curso. Em especial ao Eduardo, pela ajuda durante as intervenções cirúrgicas nos ratos $e$ pela realização das fotos das cirurgias, e ao Amélio, à Dani e à Thaís, pelo apoio nos momentos mais difíceis.

À querida Giovana, com quem dividi meus momentos alegres e tristes neste último ano em Bauru. Obrigada pelo apoio.

Às novas amizades que conquistei durante o Mestrado, Luciana, Renata, Lígia, Carla, Marcelo Zanda, Tânia, obrigada pela amizade de vocês.

Ao Fábio, pela ajuda durante as cirurgias dos ratos.

À dona Ana e ao Danilo, por receber a todos do Mestrado em Endodontia em sua casa, sempre com tanto carinho.

Aos meus amigos Jacqueline, Rosana, Marcos Alberto, Alessandra, Andréia, Geisa, Silvana, Antônio José. Obrigada pela amizade de vocês. 
Aos professores da disciplina de Cirurgia Bucomaxilofacial da FOBUSP, Prof. Dr. Osny Ferreira Júnior e Prof. Dr. Eduardo Sant'Ana, por me emprestarem os instrumentos cirúrgicos adaptados para as cirurgias nos ratos.

Aos professores e funcionários da disciplina de Histologia da FOB-USP, por permitirem que eu utilizasse o laboratório durante todo 0 processamento histotécnico. Em especial à Dani e à Tânia, pela grande ajuda prestada, pela paciência e pela amizade.

A todos os funcionários do biotério da FOB-USP, em especial ao Luís e ao Erasmo, por cuidarem dos meus ratos.

Aos professores da disciplina em Endodontia da FO-UFG, Prof. Dr. Edison Vivas de Resende, Prof. Marcos Arruda, Prof. Dr. Carlos Estrela, Profa. Marlene Tavares e, em especial, à Profo. Drạ. Ana Helena de Alencar, pelo incentivo para que eu fizesse o Mestrado.

Aos professores da Disciplina de Endodontia da FOB-USP, Prof. Dr. Clovis Monteiro Bramante, Prof. Dr. Roberto Brandão Garcia, Prof. Dr. Norberti Bernardineli, pela oportunidade de cursar o Mestrado e pelos ensinamentos passados. Em especial ao Prof. Dr. lvaldo Gomes de Moraes, pelo carinho com que sempre me recebeu, por toda a ajuda durante o curso, por triturar a ração dos meus ratos.

Aos colegas do Projeto de extensão: "Lugar de dente é a boca" da FOUFG, Alessandra Rossi, Viviane Pedatella, Adriana Santos, Denise, Gabriela, Cláudia Daniela, Ney Jorge, pelo apoio e torcida.

Aos funcionários da Disciplina de Endodontia da FOB-USP, Edimauro, Sueli, Patrícia e Dona Neide. 
Aos colegas do Doutorado em Endodontia, Rogério, Fábio, Ulisses, Renato, Everdan, Giovana, Fernanda, Viviane, Graziela e Silvana.

À FOB-USP, representada pela Diretora Profá. Drọ. Maria Fidela de Lima Navarro.

Aos funcionários da Biblioteca da FOB-USP.

Aos funcionários da Comissão de Ética no Ensino e Pesquisa em Animais.

Aos funcionários da Comissão de Pós-Graduação.

À Gisele, pela confecção do Abstract.

À Ana Amélia e ao Marcus, pela impressão da Tese. 
À Maristela, pela formatação deste trabalho.

A CAPES, pela concessão da bolsa de estudos.

A todos, enfim, que de uma forma ou de outra me ajudaram na concretização deste sonho, meus sinceros agradecimentos. 


\section{SUMÁRIO}

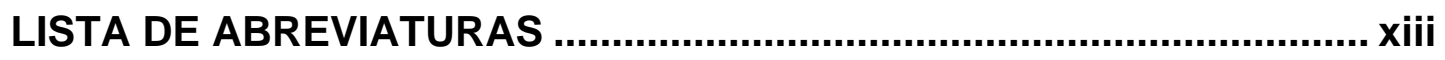

LISTA DE FIGURAS......................................................................... xiv

RESUMO ..................................................................................... Xvii

1 INTRODUÇÃO .................................................................................... 1

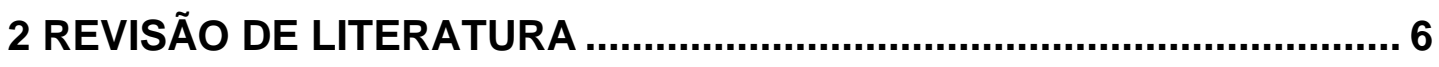

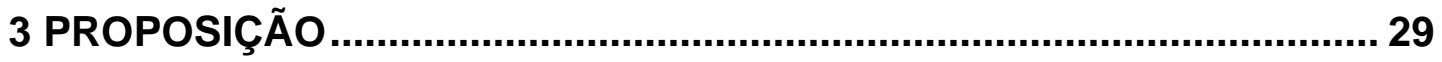

4 MATERIAL E MÉTODOS .............................................................. 31

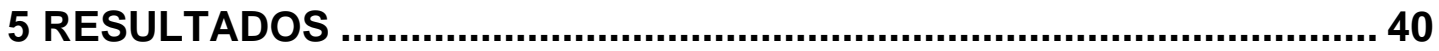

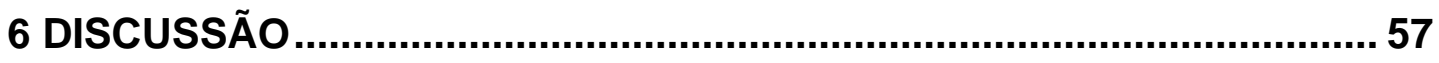

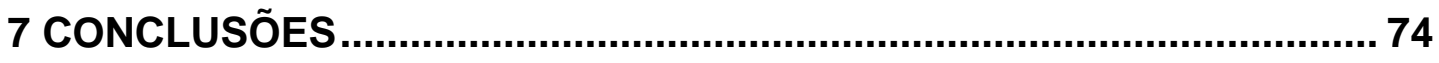

REFERÊNCIAS BIBLIOGRÁFICAS................................................... 76

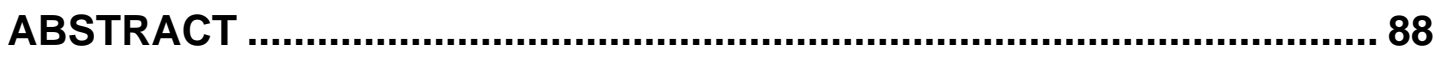




\section{LISTA DE ABREVIATURAS}

kg - quilograma

qsp - quantidade suficiente para

mg - miligrama

I - litro

U I - unidade internacional

USP - Universidade de São Paulo

$n^{\circ}$ - número

$\mathrm{ml}$ - mililitro

EDTA - ácido etilenodiaminotetracético

$\mu \mathrm{m}$ - micrometro

BMU - Unidade Osteorremodeladora

HBSS - Solução Salina Balanceada de Hank

PTH - Hormônio paratireoideano 


\section{LISTA DE FIGURAS}

FIGURA 1 - Anti-sepsia da região anterior da maxila................................ 33

FIGURA 2 - Sindesmotomia do incisivo superior direito.............................. 33

FIGURA 3 - Luxação e extração do incisivo superior direito ........................ 33

FIGURA 4 - Incisivo superior direito extraído $(\uparrow)$....................................... 33

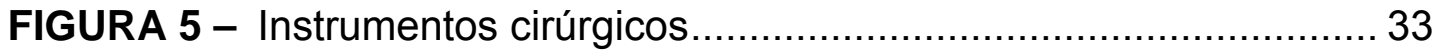

FIGURA 6 - Instrumentos cirúrgicos adaptados (parte ativa) ....................... 33

FIGURA 7 - Incisivo extraído exposto ao meio ambiente ............................. 35

FIGURA 8 - Remoção da polpa, via retrógrada............................................ 35

FIGURA 9 - Irrigação do canal radicular com soro fisiológico ....................... 35

FIGURA 10 -Secagem do canal radicular com cones de papel esterilizados 35

FIGURA 11 -Preenchimento do canal radicular com pasta de hidróxido de

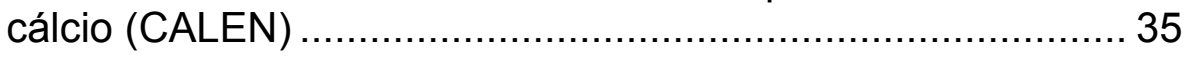

FIGURA 12 -Reimplante do incisivo superior no alvéolo 37

FIGURA 13 -Incisivo superior devidamente reposicionado 37

FIGURA 14 -Recipientes contendo soluções para tratamento da superfície radicular: $\mathrm{H}$ - Hipoclorito de sódio a $1 \%, \mathrm{~S}$ - Soro fisiológico a 0,9\%, A - Alendronato de sódio a 3,2mg/l.

FIGURA 15 -Corte longitudinal. Grupo I, 15 dias. Vista geral da superfície radicular com tecido conjuntivo neoformado, semelhante ao ligamento periodontal $(\mathbf{\Delta})$. Objetiva $2,5 \mathrm{X} \ldots \ldots \ldots \ldots \ldots \ldots \ldots \ldots \ldots \ldots . . .43$

FIGURA 16 -Corte longitudinal. Grupo I, 15 dias. Reinserção perpendicular das fibras do ligamento periodontal ( $\mathbf{\Lambda})$. Objetiva 10X.

FIGURA 17 -Corte transversal. Grupo I, 15 dias. Reinserção perpendicular

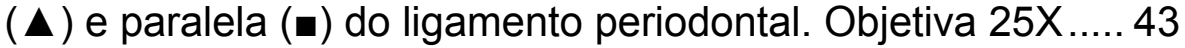


FIGURA 18 -Corte transversal. Grupo I, 15 dias. Lacunas de reabsorção inflamatória com presença de clastos (»). Objetiva 25X ......... 43

FIGURA 19 -Corte transversal. Grupo I, 15 dias. Neoformação óssea ( ) e lacunas de reabsorção (४). Objetiva 25X............................... 43

FIGURA 20 -Corte longitudinal. Grupo I, 60 dias. Fenômeno da anquilose $(\triangleright)$. Objetiva 2,5X ............................................................ 46

FIGURA 21 -Corte longitudinal. Grupo I, 60 dias. Reabsorção inflamatória comunicante com presença de clastos ( $\bullet$ ). Objetiva10X ........ 46

FIGURA 22 -Corte longitudinal. Grupo I, 90 dias. Reabsorção inflamatória comunicante (४). Objetiva 25X.

FIGURA 23 -Corte longitudinal. Grupo I, 90 dias. Reabsorção por substituição intensa $(\bullet)$. Objetiva $25 \mathrm{X}$.................................. 46

FIGURA 24 -Corte transversal. Grupo I, 90 dias. Anquilose dento-alvolar $(\triangleright)$. Objetiva 10X ................................................................ 46

FIGURA 25 -Corte longitudinal. Grupo II, 15 dias. Reinserção perpendicular (A) das fibras do ligamento periodontal, no terço cervical. Objetiva 10X 48

FIGURA 26 -Corte longitudinal. Grupo II, 15 dias. Reinserção do ligamento periodontal com fibras dispostas paralelamente (๘). Objetiva $10 \mathrm{X}$ 48

FIGURA 27 -Corte longitudinal. Grupo II, 15 dias. Neoformação óssea no ligamento periodontal $(\bullet)$. Objetiva 10X .............................. 48

FIGURA 28 -Corte longitudinal. Grupo II, 60 dias. Áreas de anquilose $(\boldsymbol{\nabla})$. Objetiva 10X

FIGURA 29 -Corte longitudinal. Grupo II, 60 dias. Reabsorção restrita ao cemento $(\bullet)$, tecido conjuntivo com fibras paralelas à superfície da raiz ( $\square$ ) e anquilose $(\square)$. Objetiva $25 X$

FIGURA 30 -Corte longitudinal. Grupo II, 90 dias. Predominância de áreas de anquilose $(\bullet)$. Objetiva $2,5 \mathrm{X}$

FIGURA 31 -Corte longitudinal. Grupo II, 90 dias. Extensas áreas de anquilose $(\triangleright)$. Objetiva 10X

FIGURA 32 -Corte longitudinal. Grupo III, 15 dias. Pequeno segmento de reinserção paralela $(\mathbf{\square})$ e perpendicular $(\mathbf{\Lambda})$ das fibras do ligamento periodontal, discreto infiltrado inflamatório. Objetiva 10X 
FIGURA 33 -Corte longitudinal. Grupo III, 15 dias. Ligamento periodontal com inserção desorganizada e células gigantes multinucleadas (匹). Objetiva 10X. 54

FIGURA 34 -Corte longitudinal. Grupo III, 60 dias. Áreas de anquilose ( ) e segmentos de ligamento periodontal (๓). Objetiva 10X .......... 54

FIGURA 35 -Corte longitudinal. Grupo III, 60 dias. Tecido conjuntivo neoformado e desorganizado no terço apical (-), além de segmentos de anquilose ( $)$. Objetiva 10X............................. 54

FIGURA 36 -Corte longitudinal. Grupo III, 90 dias. Anquilose ( pequenas áreas de tecido conjuntivo com discreto infiltrado inflamatório crônico com algumas células gigantes (ם). Objetiva 10X.

FIGURA 37 -Corte longitudinal. Grupo III, 90 dias. Anquilose $(\triangleright)$ e foco de reação inflamatória crônica discreta com algumas células gigantes multinucleadas (ฮ). Objetiva 25X. 54

FIGURA 38 -Sinopse dos eventos microscópicos observados nos diferentes grupos e períodos experimentais. 56 
Resumo 


\section{RESUMO}

O tratamento de escolha para a avulsão dentária é o reimplante. O ideal é que este seja realizado o mais rapidamente possível ou, pelo menos, que o dente avulsionado seja mantido em meios compatíveis com a manutenção da vitalidade do tecido periodontal aderido à raiz. Se isso não for possível, o tratamento da superfície radicular deverá ser instituído com o objetivo de prevenir a reabsorção radicular. $\mathrm{O}$ objetivo deste trabalho foi testar o alendronato de sódio como substância para tratamento tópico da superfície radicular a fim de evitar a ocorrência do processo reabsortivo. Para isso, foram utilizados 54 incisivos superiores direitos de ratos, extraídos e reimplantados, assim divididos: no grupo I, o período extra-alveolar foi de 15 minutos e, após o preenchimento do canal radicular com pasta de hidróxido de cálcio $\left(\mathrm{CALEN}^{\circledR}\right)$, via retrógrada, os dentes foram reimplantados. Nos grupos II e III, o tempo de permanência em meio ambiente a seco foi de 30 e 60 minutos, respectivamente. Nestes grupos, os dentes foram imersos em solução de hipoclorito de sódio a $1 \%$ por 30 minutos para remoção do ligamento periodontal cementário, lavados em soro fisiológico por 5 minutos e tiveram a superfície radicular tratada com solução de alendronato de sódio a $3,2 \mathrm{mg} / \mathrm{l}$ por 10 minutos. Os canais radiculares foram aspirados e preenchidos com pasta de hidróxido de cálcio $\left(\right.$ CALEN $\left.^{\circledR}\right)$, via retrógrada e, em seguida, reimplantados. Transcorridos os períodos de 15, 60 e 90 dias do reimplante, os animais foram mortos, as peças obtidas e processadas em laboratório para análise microscópica. Os resultados mostraram que o alendronato de sódio foi capaz de diminuir a incidência de reabsorção radicular, mas não de anquilose dento-alveolar. A variação do tempo extra-alveolar entre os grupos II e III não revelou diferenças significativas nos resultados obtidos. 


\section{INTRODUÇÃo}




\section{INTRODUÇÃO}

As lesões traumáticas dos dentes anteriores permanentes têm se tornado cada vez mais freqüentes, atingindo principalmente crianças na fase escolar, de 7 a 14 anos (ANDREASEN; ANDREASEN ${ }^{14}$, 1994). Nesta faixa etária as crianças vivem em intensa atividade física e possuem pouca noção do perigo. A prática de esportes e outras brincadeiras, aliadas às características anatômicas peculiares à idade, como protrusão fisiológica dos incisivos centrais superiores, por ocasião da erupção dos caninos permanentes, predispõem, sobremaneira, ao traumatismo dentário (JÄRVINEN ${ }^{65}$, 1979; OIKARINEN; KASSILA ${ }^{93}$, 1987). As conseqüências desses acidentes vão desde pequenas fraturas coronárias, até o completo deslocamento do dente do seu alvéolo, o que caracteriza a avulsão. Cerca de $16 \%$ de todas as lesões traumáticas dos dentes permanentes resultam em avulsão (ANDREASEN ${ }^{5}$, 1970). O tratamento, nesses casos, é o reposicionamento do dente no alvéolo, ou seja, a realização do reimplante dentário, importantíssimo para o restabelecimento das suas funções normais (ANDREASEN; ANDREASEN ${ }^{14}$, 1994). O reimplante dentário, ou seja, o ato de reposicionar o dente avulsionado em seu alvéolo, é o tratamento preconizado para os traumatismos que provocam avulsão (ALEXANDER ${ }^{1}$, 1956).

Quando o dente avulsionado é reimplantado imediatamente ou é armazenado em meios compatíveis para a manutenção da vitalidade das fibras do ligamento periodontal presentes na raiz, aumentam-se consideravelmente as chances de sucesso do procedimento executado (ANDERSSON; BODIN ${ }^{3}$, 1990; ANDREASEN ${ }^{8}, 1980 ;$ ANDREASEN $^{9}, 1981$; ANDREASEN et al. ${ }^{20}$, 1995, ANDREASEN; KRISTERSON ${ }^{17}$, 1981). Assim, os meios úmidos de conservação como o leite, por exemplo, favorecem o êxito do reimplante dentário (HAMMARSTRÖM, et al. ${ }^{56}$, 1986; LINDSKOG; BLOMLÖF $^{78}$, 1982, PETTIETTE, et al. ${ }^{101}$, 1997), enquanto que a 
conservação em meio ambiente seco ou em meios impróprios piora significativamente o prognóstico (PETTIETTE, et al. ${ }^{101}, 1997$ ).

Dentre as conseqüências da avulsão e seu posterior reimplante está a reabsorção radicular (ANDREASEN; ANDREASEN ${ }^{14}$, 1994) e seu aparecimento está na dependência de alguns fatores como tempo extraalveolar (ANDREASEN ${ }^{9}, 1981$ ), meio de conservação do dente avulsionado (ANDREASEN et al. ${ }^{18}$, 1995), já citados, além da contaminação microbiana (MINKIN; JENNINGS ${ }^{83}$, 1972) e estágio de formação radicular (ANDREASEN et al. ${ }^{19}$, 1995).

As reabsorções dentárias recebem classificações variadas e seu tratamento vem sendo amplamente estudado. Em 1988, TRONSTAD ${ }^{122}$ classificou as reabsorções em inflamatória e por substituição. A reabsorção inflamatória pode ser classificada ainda em interna, quando ocorre na parede da cavidade pulpar ou externa, quando ocorre na superfície externa da raiz, podendo ser transitória ou progressiva e, quando ocorre na superfície externa no terço cervical, recebe a classificação de reabsorção cervical. A reabsorção por substituição ocorre quando, após a anquilose, a superfície radicular vai sendo gradativamente substituída por tecido ósseo. ANDREASEN; ANDREASEN ${ }^{14}$, em 1994, apresentaram outra classificação para as reabsorções: reabsorção da superfície radicular (reabsorção radicular externa), que pode ser superficial, inflamatória ou por substituição, além da reabsorção do canal radicular (reabsorção radicular interna), que pode ser interna superficial, interna inflamatória ou interna por substituição. Em 2003, FUSS; TSESIS; LIN ${ }^{50}$ apresentaram uma classificação para as reabsorções radiculares de acordo com o fator estimulador. Assim, a classificação foi a seguinte: reabsorção por infecção pulpar, reabsorção por infecção periodontal, reabsorção por pressão ortodôntica, reabsorção por pressão tumoral ou dente impactado e reabsorção por substituição.

No momento da reimplantação do elemento dentário, dependendo do meio de conservação e do tempo extra-alveolar, condutas diversas podem ser estabelecidas. O tempo extra-alveolar até quinze minutos torna o 
prognóstico do reimplante favorável e somente o tratamento endodôntico deverá ser instituído posteriormente (ANDERSSON; BODIN ${ }^{3}$, 1990). Para esses casos o reimplante é considerado imediato. Em contrapartida, passado o período de quinze minutos a seco, se o dente avulsionado não for conservado em meio adequado, o tecido do ligamento periodontal, presente na superfície radicular, poderá se ressecar e, conseqüentemente, necrosar, tornando o prognóstico desfavorável (ANDREASEN; KRISTERSON ${ }^{17}, 1981$; OKAMOTO et al. $\left.{ }^{96}, 1995\right)$. O reimplante, então, é chamado tardio e, nesse caso, o tratamento da superfície radicular deverá ser executado, removendo o ligamento periodontal necrosado (KANNO ${ }^{67}, 1996$; LINDSKOG et al. ${ }^{79}$, 1985; MURAD $\left.{ }^{87}, 1982\right)$, hidratando algum remanescente viável do ligamento periodontal e aplicando na superfície da raiz substâncias, com a finalidade de preservar a estrutura da radicular (BJORVATN; MASSLER ${ }^{25}, 1971$; SHULMAM; GEDALIA; FEINGOLD ${ }^{115}$, 1973; SONODA ${ }^{119}$, 1997). Estas substâncias bloqueariam a ação de células reabsortivas (BJORVATN; $M_{A S S L E R}{ }^{25}$, 1971) e induziriam a neoformação de cemento (FILLIPI; POHL; VON ARX ${ }^{45}$, 2001; IQBAL; BAMAAS ${ }^{63}, 2001$ ).

Há uma vasta relação dessas substâncias na literatura, como formalina, álcool, água aquecida (BUTCHER; VIDAIR $\left.{ }^{31}, 1955\right)$, ácido cítrico (ESCOBAR $^{43}$, 1997; PERCINOTO ${ }^{100}$, 1986; POLSON; PROYE ${ }^{104}, 1982$ ), fluoretos (BJORVATN; MASSLER ${ }^{25}$, 1971; SHULMAM; GEDALIA; FEINGOLD ${ }^{115}, 1973$; SONODA ${ }^{119}, 1997$ ), enzimas (NEVINS et al. ${ }^{91}, 1980$ ), solução de hidróxido de cálcio (ISOLAN; PERRI DE CAVALHO ${ }^{64}, 1989$ ), antibióticos locais e/ou sistêmicos (BRYSON et al. ${ }^{30}$, 2003; SAE-LIM et al. ${ }^{108}$, 1998), antiinflamatórios (KEUM et al. ${ }^{69}, 2003$ ), hipoclorito de sódio (KANNO ${ }^{67}$, 1996; LINDSKOG et al. ${ }^{79}$, 1985; SONODA et al. ${ }^{120}, 2000$ ), proteína derivada da matriz do esmalte (FILLIPI; POHL; VON ARX ${ }^{45}, 2001$; IQBAL; BAMAAS $\left.{ }^{63}, 2001\right)$, acetazolamida $\left(M^{2}{ }^{85}{ }^{85}, 2002\right)$ e os bifosfonatos (LEVIN et al. ${ }^{75}, 2001$; LIEWEHR et al. $\left.{ }^{76}, 1995\right)$.

Existe uma grande família desses compostos bifosfonatos que vêm sendo usados ou desenvolvidos para o tratamento de doenças ósseas. 
São eles o alendronato, o clodronato, o EB-1053, o etidronato, o ibandronato, o icandronato, o neridronato, o olpadronato, o pamidronato, 0 risedronato, o tiludronato, o YH 529 e o zoledronato (RODAN ${ }^{106}$, 1998). Dentre eles, o alendronato tem se mostrado muito eficaz no tratamento clínico da osteoporose (SELBY $\left.{ }^{113}, 1996\right)$ e tem também apresentado elevado efeito inibitório da reabsorção óssea pela inibição dos osteoclastos (MASARACHIA et al. ${ }^{82}$, 1996). Em adição a esse potente efeito inibidor da reabsorção óssea, alguns estudos têm mostrado também efeito direto sobre a neoformação óssea (IGARASHI et al. $^{62}$, 1997; SAHNI et al. ${ }^{110}$, 1993; TSUCHIMOTO et al. ${ }^{127}$, 1994; VITTE et al. ${ }^{128}$, 1996).

Os compostos bifosfonatos têm sido usados topicamente em pesquisas odontológicas e revelado alguns resultados satisfatórios (LEVIN, et al. ${ }^{75}$, 2001; SOMMERCORN, et al. ${ }^{121}$, 2000). Dessa forma, é oportuno estudar o efeito tópico do alendronato em reimplante dentário. 


\section{REVISÃO DE LITERATURA}




\section{REVISÃO DE LITERATURA}

Para melhor compreensão do assunto, a revisão de literatura será dividida em tópicos assim relacionados: avulsão e reimplante dentário, tratamento de superfície radicular, conseqüências do reimplante, terapêutica endodôntica e alendronato, potente inibidor da atividade osteoclástica.

\subsection{AVULSÃO E REIMPLANTE DENTÁRIO}

Os traumatismos dentários, de um modo geral, têm sido classificados de acordo com uma variedade de fatores, tais como etiologia, anatomia, patologia, ou considerações terapêuticas e vão desde pequenas fraturas coronárias, até o completo deslocamento do dente do seu alvéolo, o que caracteriza a avulsão dentária (ANDREASEN; ANDREASEN ${ }^{14}$, em 1994). A classificação adotada por esses autores segue a Aplicação da Classificação Internacional das Doenças na Odontologia e Estomatologia da Organização Mundial de Saúde (OMS), porém de uma forma mais completa, incluindo certos tipos de traumatismos não citados no sistema da OMS.

A avulsão de dentes após lesões traumáticas é relativamente pouco freqüente, variando de 0,5 a $16 \%$ das lesões traumáticas na dentição permanente e os principais fatores etiológicos nessa dentição são as brigas e os esportes (ANDREASEN ${ }^{5}, 1970$ ). Os incisivos centrais superiores são os dentes mais comumente atingidos, ao passo que a mandíbula raramente é afetada. A idade mais freqüente para ocorrência da avulsão é entre 7 e 9 anos de idade, fase esta em que os incisivos permanentes estão erupcionando. Nesta idade o ligamento periodontal mais resiliente oferece apenas uma pequena resistência a uma força extrusiva (ANDREASEN et al. $17,18,1995)$. 
O tratamento, nos casos de avulsão, é o reimplante dentário, fundamental para $\mathrm{O}$ restabelecimento do aparelho estomatognático (ANDREASEN; ANDREASEN ${ }^{14}, 1994$ ).

O reimplante dentário, definido como o ato de reposicionar 0 dente em seu alvéolo após a sua avulsão (ALEXANDER ${ }^{1}$, 1956), na maioria das situações, mesmo com um prognóstico duvidoso, deve ser realizado. $O$ plano de tratamento definitivo raramente pode ser feito no afã do tratamento emergencial. Deve se ter em mente que o momento do atendimento imediatamente após o traumatismo, freqüentemente não é o ideal para se tomar decisões. Posteriormente, após a realização do reimplante dentário e uma consulta com um especialista, decide-se a viabilidade de manter 0 dente reimplantado ou não (ANDREASEN; ANDREASEN ${ }^{14}$, 1994).

O reimplante dentário tem sido bastante estudado nos últimos anos. Em 1970, GROPER; BERNICK ${ }^{51}$ analisaram dentes de cães reimplantados variando os tempos extra-alveolares $(0,10,15$ e 30 minutos; $1,3,8$ e 24 horas) e concluíram que, quanto maior for o tempo extraalveolar, pior será o prognóstico para o dente reimplantado e que, a partir de uma hora, a possibilidade de reparo piora significantemente. ANDREASEN ${ }^{6}$, em 1980, em trabalho semelhante com macacos, comparou dentes reimplantados após diferentes tempos extra-alveolares e constatou que aqueles reimplantados após 120 minutos apresentaram maiores áreas de reabsorção. Em outro trabalho ANDREASEN ${ }^{7}$ (1980) observou também que quando os dentes eram reimplantados imediatamente após a avulsão as áreas de destruição radiculares eram menores do que aquelas cujos dentes permaneciam mais de 18 minutos fora do alvéolo.

\section{Em 1989, HAMMARSTRÖM; BLOMLÖF; LINDSKOG ${ }^{53}$} compararam os diferentes resultados de dentes de macacos reimplantados após tempo extra-alveolar a seco por 15 minutos e 1 hora. Os autores concluíram que nos dentes que permaneceram fora do alvéolo por até 15 minutos, as condições para o reparo estavam presentes e estabeleceram esse tempo como aceitável para o reimplante. Estudo semelhante foi 
realizado em humanos por ANDERSSON; BODIN ${ }^{3}$, em 1990, com 21 dentes que permaneceram em meio ambiente por até 15 minutos, de modo que a maioria, 15 dentes, apresentou a estrutura radicular preservada.

A literatura tem demonstrado que o fator tempo é de extrema importância para o sucesso do reimplante dentário, salientando que até quinze minutos de permanência do dente fora do seu alvéolo é tido como ideal e o reimplante realizado dentro desse período é considerado imediato. No reimplante imediato o prognóstico será melhor, pois as chances de reparo e de restabelecimento da função são significativamente maiores, uma vez que se evitará o ressecamento e, conseqüentemente, a necrose do ligamento periodontal e da polpa dentária. A preservação da vitalidade dessas células, principalmente do ligamento periodontal, é fundamental para o sucesso do reimplante (ANDREASEN et al. ${ }^{19,20}$, 1995; HAMMARSTRÖM; BLOMLÖF; LINDSKOG ${ }^{53}$, 1989; LÖE; WAERHAUG ${ }^{81}$, 1961; NEVINS et al. $\left.{ }^{91}, 1980\right)$.

No entanto, na grande maioria das situações envolvendo a avulsão dentária, os dentes raramente são reimplantados dentro desse intervalo de tempo, já que os pacientes ou são incapazes de realizarem, eles próprios, o reimplante no momento do acidente, o que seria o ideal, ou demoram a comparecer ao consultório odontológico para que o profissional o faça. Por isso, um fator a ser considerado é o meio de conservação para o dente avulsionado até que se possa proceder ao reimplante com o objetivo de manter a vitalidade e, em alguns casos, a viabilidade das células presentes sobre a superfície radicular pelo maior tempo possível (ANDREASEN; ANDREASEN ${ }^{14}$, 1994; ANDREASEN et al. $^{20}$, 1995). A vitalidade da célula pode ser definida como sua capacidade de produzir energia para a manutenção das funções orgânicas básicas, enquanto a viabilidade é a possibilidade de multiplicação celular, ou seja, de realizar mitose (LEKIC et al. ${ }^{71}$, 1996; PATIL et al. ${ }^{99}$, 1994). 
Muitos meios de conservação já foram testados, sendo que o meio úmido é a melhor opção, podendo ser utilizado: água, soro fisiológico, saliva, leite e meios de cultura (BARRET; KENNY23, 1997).

A conservação do dente avulsionado em meio úmido já representa um cuidado que acarretará algum benefício após a reimplantação. OSWALD; HARRINGTON; VAN HASSEL ${ }^{97}$, em 1980, comparando a conservação de dentes avulsionados em saliva e em meio seco por 90 minutos, observaram melhores resultados naqueles conservados em meio úmido. Os meios secos de armazenamento de dentes avulsionados, como expostos ao meio ambiente ou embrulhados em pedaços de papel, são desfavoráveis à vitalidade e à viabilidade do remanescente de tecido conjuntivo aderido à superfície radicular, comprometendo o prognóstico do reimplante dentário.

LINDSKOG; BLOMLÖF ${ }^{78}$, em 1982, compararam in vitro os efeitos da água de torneira, solução de sucrose, saliva, leite, solução salina e meio de cultura de tecido. Foram obtidas culturas de células de ligamento periodontal humano e um osmômero foi utilizado para a análise da osmolaridade. Os autores observaram melhores resultados quando da utilização do meio de cultura de tecido, leite e solução salina, onde a osmolaridade variou entre 242-291 mOsm/kg. Os excelentes resultados apresentados por essas substâncias foram devidos principalmente à alta osmolaridade dessas substâncias, que é mais compatível com a sobrevivência das células presentes na superfície radicular. Quanto à saliva, devido à sua hipotonicidade e à possível existência de bactérias, ela poderia levar à morte celular. HAMMARSTRÖM et al. ${ }^{56}$, em 1986, alertaram que a permanência do dente avulsionado no leite não deverá exceder a seis horas.

Quanto aos meios de cultura, a solução salina balanceada de Hank (HBSS) mostrou-se superior ao leite, uma vez que proporcionou bons resultados mesmo quando o dente permaneceu em meio extra-alveolar por até 12 horas (HILTZ; TROPE ${ }^{60}$, 1991). Já o Viaspan, usado como meio para armazenamento de órgãos a serem transplantados, mostrou melhores 
resultados quando comparado com o HBSS (HILTZ; TROPE ${ }^{60}$, 1991; PETTIETTE et al. ${ }^{101}$, 1997).

Assim, os meios de conservação indicados para o armazenamento de dentes avulsionados até o momento do reimplante, em ordem de preferência, são: meios de cultura (Viaspan ou HBSS), leite, solução salina, saliva e água (TROPE $\left.{ }^{124}, 2002\right)$.

Além do tempo extra-alveolar e do meio de conservação utilizado para o dente avulsionado, deve-se considerar o estágio de formação da raiz. A reimplantação de dentes com rizogênese incompleta sob condições adequadas pode propiciar a revascularização pulpar, o que evitaria a necrose pulpar e levaria a um prognóstico mais favorável (ANDREASEN et al. $\left.^{19}, 1995\right)$.

Outros fatores também devem ser avaliados, como a presença de contaminação microbiana (NISHIOKA et al. ${ }^{92}$, 1998), a idade do paciente (ANDREASEN et al. ${ }^{18}$, 1995; EBELESEDER et al. ${ }^{41}$, 1998), o tipo e o tempo de contenção a ser utilizada após o reimplante dentário (COCCIA $\left.{ }^{33}, 1980\right)$.

\subsection{TRATAMENTO DA SUPERFÍCIE RADICULAR}

Existem excelentes meios para a conservação de dentes avulsionados que permitem períodos extra-alveolares bastante prolongados até a realização do reimplante, mas pelo fato destes não estarem disponíveis no momento do acidente, sua utilização torna-se pouco viável (TROPE $\left.^{124}, 2002\right)$.

Dentes avulsionados que foram mantidos a seco por períodos superiores a duas horas têm chance de sucesso inferior a 1\% (LINDSKOG et al. $^{79}$, 1985). Para os casos onde se pode presumir que o ligamento periodontal está necrosado, tem-se sugerido o tratamento da superfície radicular com diversas substâncias para tentar inibir a reabsorção radicular e 
melhorar o prognóstico dos dentes avulsionados e reimplantados, tais como formalina, álcool, água aquecida (BUTCHER; VIDAIR ${ }^{31}$, 1955), ácido cítrico (ESCOBAR $^{43}$, 1997; PERCINOTO ${ }^{100}$, 1986; POLSON; PROYE ${ }^{104}$, 1982), fluoretos (BJORVATN; MASSLER ${ }^{25}$, 1971; SHULMAM; GEDALIA; FEINGOLD ${ }^{115}$, 1973; SONODA $\left.{ }^{119}, 1997\right)$, enzimas (NEVINS et al. ${ }^{91}, 1980$ ), solução de hidróxido de cálcio (ISOLAN; PERRI DE CAVALHO ${ }^{64}, 1989$ ), antibióticos locais e/ou sistêmicos (BRYSON et al. ${ }^{30}$, 2003; SAE-LIM et al. 108 , 1998), antiinflamatórios (KEUM et al. ${ }^{69}$, 2003), hipoclorito de sódio (KANNO ${ }^{67}$, 1996; LINDSKOG et al. ${ }^{79}$, 1985; SONODA et al. ${ }^{120}$, 2000), proteína derivada da matriz do esmalte (FILLIPI; POHL; VON ARX ${ }^{45}$, 2001; IQBAL; BAMAAS ${ }^{63}, 2001$ ) e os bifosfonatos (LEVIN et al. ${ }^{75}$, 2001; LIEWEHR et al. $\left.{ }^{76}, 1995\right)$.

A importância ou não da presença do ligamento periodontal e da vitalidade de suas células para o reimplante foi estudada por LÖE, WAERHAUG ${ }^{81}$, em 1961, em dentes de cães e macacos. Três grupos foram avaliados: dentes sem ligamento periodontal, dentes com ligamento necrosado e dentes com ligamento vital. Os resultados microscópicos demonstraram a importância da vitalidade das células do ligamento periodontal cementário para a ocorrência do reparo. Nesse sentido, ANDREASEN, em $1981^{10}$ mostrou que, quando células necrosadas do ligamento periodontal estavam presentes no momento do reimplante, havia o desenvolvimento da reabsorção radicular. ANDREASEN; KRISTERSON ${ }^{17}$, em 1981, comprovaram que quando o reimplante é realizado com o ligamento periodontal sem vitalidade, pode ocorrer a sua substituição por tecido ósseo, instalando-se a anquilose e a reabsorção por substituição. Desse modo, OKAMOTO et al. ${ }^{96}$, em 1995 , em um trabalho realizado em ratos, comprovaram que a preservação do ligamento periodontal sem vitalidade, no momento do reimplante, é um fator prejudicial ao reparo e, portanto, o mesmo deverá ser removido.

Buscando estudar a influência ou não do ligamento periodontal remanescente na superfície radicular e no alvéolo na neoformação desse 
tecido em dentes reimplantados, ANDREASEN ${ }^{11}$, em 1981, realizou um trabalho com macacos dividindo os espécimes em 8 grupos, com diferentes tempos de permanência extra-alveolar e com remoção ou não dos remanescentes presentes na superfície radicular e no alvéolo. Para a remoção dos restos de ligamento da superfície cementária e alveolar utilizou brocas e curetas. O autor concluiu que a remoção do ligamento aderido à superfície alveolar não alterou o reparo, enquanto que, com a remoção do ligamento aderido à superfície do cemento levou ao surgimento de áreas de reabsorção.

MURAD $^{87}$, em 1982, trabalhou com dentes de cães com o propósito de verificar a influência da remoção do ligamento periodontal e da polpa, em dentes reimplantados imediatamente à extração e com o canal radicular preenchido com hidróxido de cálcio. Os resultados demonstraram que, quando o ligamento foi removido e o canal radicular preenchido com hidróxido de cálcio, lacunas de reabsorção radicular foram menores e menos freqüentes.

A análise de POLSON; PROYE ${ }^{104}$, em 1982, em dentes de macacos reimplantados após raspagem ou tratamento da superfície radicular com ácido cítrico por 3 minutos, demonstrou que, nos dentes reimplantados com a superfície radicular raspada, houve migração do epitélio gengival sobre a superfície radicular, o que não foi visto no outro grupo. NAKANE; KAMEYAMA ${ }^{89}$, em 1987, também mostraram que a raspagem mecânica da superfície radicular em dentes de ratos levaria ao desenvolvimento de reabsorções radiculares. Em 1994, BLOMLÖF; LINDSKOG $^{27}$, avaliando 24 dentes de macacos como modelo experimental, comprovaram que a remoção do ligamento periodontal e do cemento provocou a ocorrência de anquilose e reabsorção radicular.

O efeito do hipoclorito de sódio a $1 \%$ em dentes de ratos avulsionados e reimplantados foi avaliado por KANNO ${ }^{67}$, em 1996. Para isso, os dentes foram mantidos em meio ambiente seco por 30 minutos e divididos em dois grupos: um teve a superfície radicular tratada com aquela 
substância, enquanto que o outro grupo não recebeu nenhum tratamento. Os resultados demonstraram que as raízes dos dentes tratados com hipoclorito de sódio a $1 \%$ apresentaram-se encapsuladas nos períodos mais curtos enquanto que no grupo sem tratamento foram observadas anquilose, reabsorção por substituição e algumas áreas de ligamento periodontal neoformado.

RENON $^{105}$, em 1999, comparou o efeito de três tratamentos diferentes para a superfície radicular de dentes de ratos, avulsionados e reimplantados. Após exposição da superfície radicular por 15 minutos em meio ambiente, os dentes foram divididos em três grupos experimentais antes da realização do reimplante. No primeiro, os dentes foram mantidos em soro fisiológico por 20 minutos. No segundo, imersos em hipoclorito de sódio a $1 \%$ por 20 minutos e, no terceiro, tiveram a superfície radicular raspada e tratada por 20 minutos com hipoclorito de sódio a $1 \%$. Os resultados mostraram que quando o reimplante é imediato, somente a hidratação da superfície é necessária e que a remoção do ligamento periodontal somente com hipoclorito é melhor do que com a raspagem da superfície radicular, pois no grupo onde a superfície radicular foi alisada as áreas de reabsorção e anquilose foram maiores.

O grande número de pesquisas sobre $\mathrm{O}$ uso do hipoclorito de sódio para a remoção do ligamento periodontal estimularam SONODA et al. ${ }^{120}$, em 2000, a avaliarem a utilização de solução de hipoclorito de sódio em diferentes concentrações em dentes avulsionados de ratos. Os dentes, após a extração simulando a avulsão, permaneceram por 1 hora em solução de hipoclorito de sódio nas concentrações de 1\%,2,5\%, $5 \%$ e $10 \%$ e, em seguida, foram reimplantados. Todas as concentrações foram eficazes para a remoção do ligamento periodontal, porém os autores concluíram que a utilização das soluções a $1 \%$ ou $2,5 \%$ estava mais bem indicada para esse fim, por serem menos agressivas aos tecidos.

Buscando avaliar a influência de diferentes volumes da solução de hipoclorito de sódio a $1 \%$ para a remoção do ligamento periodontal em 
dentes de ratos, POI et al. ${ }^{103}$, em 2001, pesquisaram a eficácia de quatro diferentes volumes dessa solução. Os autores utilizaram 10, 20, 50 e $100 \mathrm{ml}$ para a imersão dos dentes extraídos e concluíram que quanto maior o volume da solução, maior a quantidade de tecido removida, porém os grupos de 50 e $100 \mathrm{ml}$ se comportaram de modo semelhante.

Na tentativa de evitar a reabsorção radicular, muitas substâncias têm sido aplicadas sobre a superfície radicular, associadas ou não com a remoção do ligamento periodontal.

Um dos primeiros estudos testando o fluoreto de sódio como substância para prevenção da reabsorção foi realizado em 1968 por SHULMAN; KALIS; GOLDHABER ${ }^{116}$. Eles imergiram em solução de fluoreto de sódio, dentes de macacos a serem reimplantados tardiamente. Os resultados sugeriram que este procedimento poderia atenuar o processo reabsortivo.

A partir daí, outros trabalhos foram realizados para verificar a influência benéfica do flúor no tratamento das reabsorções radiculares. Em 1971, BJORVANTN; MASSLER ${ }^{25}$ realizaram um trabalho onde dentes de ratos reimplantados permaneceram expostos ao meio ambiente a seco por 30 a 60 minutos e, a seguir, receberam tratamento de superfície radicular por 5 minutos, com solução saturada de fluoreto estanhoso a $10 \% \mathrm{pH}$ 2,2. Em outro experimento, citado neste mesmo trabalho, os dentes foram tratados com fluoreto de sódio a $2 \%$ e fluoreto estanhoso a $1 \%$, também por 5 minutos. Concluiu-se que a concentração de fluoreto estanhoso a $1 \%$ favoreceu o melhor reparo do ligamento periodontal, o que não ocorreu na concentração de 10\%. Foi observado também, em concordância com o trabalho de SHULMAN; KALIS; GOLDHABER ${ }^{116}$, em 1968, que a utilização do flúor diminuiu as áreas de reabsorção radicular. Os autores explicaram que poderia haver a formação de fluorapatita, que é mais resistente à reabsorção ou que o flúor poderia ter efeito inibitório na diferenciação dos clastos (BJORVANTN; MASSLER ${ }^{25}$, 1971; SHULMAN; GEDALIA; FEINGOLD $\left.{ }^{115}, 1973\right)$. 
Em 1989, BJORVATN; SELVIG; KLINGE ${ }^{26}$ testaram o efeito do fluoreto de estanho, da tetraciclina e da associação dessas duas substâncias no tratamento de dentes de cães avulsionados e reimplantados. Nos dentes tratados somente com tetraciclina, aproximadamente $27 \%$ da superfície radicular foi reabsorvida, enquanto que nos demais dentes tratados com fluoreto de estanho associado ou não à tetraciclina, somente $1 \%$ da superfície apresentou-se reabsorvida.

Seguindo a linha de pesquisa em que se associava a tetraciclina ao fluoreto de estanho, em 1992, SELVIG et al. ${ }^{114}$ analisaram a ação da solução de fluoreto de estanho a $0,1 \%$ e da tetraciclina em dentes reimplantados, onde os dentes avulsionados, após permanecerem em meio ambiente por 45 minutos, foram divididos em dois grupos: um sem tratamento de superfície; outro, onde se usou fluoreto de estanho seguido da tetraciclina. Em seguida, os dentes foram reimplantados. Os autores observaram que a superfície radicular foi mais afetada pela anquilose e reabsorção no grupo em que nenhum tratamento foi utilizado. Concluíram ainda, que o flúor e a tetraciclina apresentam efeito sinérgico e que a concentração de $0,1 \%$ foi menos efetiva do que a de $1 \%$ para a prevenção da ocorrência da anquilose.

Outras substâncias passaram a ser testadas para comparar seus efeitos com os do flúor no tratamento das reabsorções. WIKESJÖ et al. ${ }^{129}$, em 1991, usando cães como modelo experimental, submeteram a superfície radicular dos dentes à raspagem que, em seguida, foram tratadas com fluoreto de estanho a $1 \%$, ácido cítrico ou soro fisiológico. Os dentes tratados com soro fisiológico e ácido cítrico apresentaram reabsorções semelhantes, enquanto que, nos dentes tratados com fluoreto de estanho, a reabsorção radicular foi mais rara.

Contrariando o trabalho anterior, PERCINOTO ${ }^{100}$, em 1986, também testou o efeito do ácido cítrico no tratamento da reabsorção radicular e verificou que dentes de cães imersos em hipoclorito de sódio a $5 \%$ por 1 hora e, em seguida, tratados com ácido cítrico a 10\% por 1 minuto, 
mostraram neoformação cementária, reinserção de fibras e pouca ocorrência de anquilose.

Em concordância com PERCINOTO ${ }^{100}$, ESCOBAR ${ }^{43}$, em 1997, observou que quando se utilizou o ácido cítrico a $10 \%$ após o uso do hipoclorito de sódio a $5 \%$, poucas áreas de reabsorção foram observadas. Porém, este autor, contrariando os achados de ESCOBAR ${ }^{43}$, observou grandes áreas de anquilose presentes. Em contrapartida, em dentes onde se utilizou apenas o hipoclorito de sódio os eventos reabsortivos foram bastante severos.

SONODA $^{119}$, 1997, comparou o efeito do hipoclorito de sódio a $2 \%$, fluoreto de sódio a $2 \%$ ou associação dos dois em dentes de cães que foram avulsionados e mantidos por 60 minutos em meio ambiente seco. As maiores áreas de anquilose foram observadas no grupo tratado somente com flúor. O hipoclorito de sódio diminuiu, mas não eliminou a reabsorção radicular e a anquilose e no grupo onde se associou o hipoclorito de sódio a $2 \%$ ao fluoreto de sódio a $2 \%$, maior quantidade de tecido dentário foi preservada e as áreas de anquilose apresentaram-se reduzidas.

PANZARINI ${ }^{98}$, em 2001, submeteu dentes de ratos avulsionados ao tratamento de superfície radicular com hipoclorito de sódio a $1 \%$ seguidos da aplicação de fluoreto de sódio a $2 \%$ ou solução de vitamina C, anteriormente ao reimplante. Foi constatado que tanto o uso do flúor quanto da vitamina $C$ não evitou áreas de anquilose e reabsorção por substituição.

BRYSON et al. ${ }^{30}$, em 2003 , testaram o efeito da monociclina sobre o reparo do ligamento periodontal de dentes de cães reimplantados após período extra-alveolar a seco de 60 minutos. Um grupo recebeu tratamento da superfície radicular com a monociclina antes do reimplante e o outro não. Os autores concluíram que o uso tópico desse medicamento não atenuou, nem preveniu a ocorrência de reabsorções. Esses autores afirmaram, ainda, que o uso combinado de tetraciclina com outros medicamentos como Ledermix $^{\circledR}$, Emdogain $^{\circledR}$ e Alendronato $^{\circledR}$ podem 
promover efeito sinérgico na prevenção das reabsorções radiculares externas após avulsão.

\subsection{CONSEQÜÊNCIAS DO REIMPLANTE}

A patologia do reimplante dentário pode ser dividida em reações pulpares e reações periodontais. Tanto a polpa quanto o ligamento periodontal sofrem danos extensos quando avulsionados e as reações de reparo dependem do período e da manipulação extra-alveolar, bem como do meio utilizado para a conservação do dente avulsionado até o momento do reimplante (ANDREASEN; ANDREASEN ${ }^{14}$, 1994).

O processo de reparo após o reimplante tem sido objeto de estudo em numerosos experimentos usando ratos ${ }^{92,94,95,98,105,}$ cães $^{24,87,100,}$ 119, 125 , macacos ${ }^{6-11,32}$ e humanos $^{1,3,15,16,18-20}$. A expectativa é que haja 0 restabelecimento da função do dente reimplantado, entretanto situações adversas podem ocorrer, como a anquilose e as reabsorções radiculares ${ }^{12}$, $13,14,16,32$

Em 1966, ANDREASEN; HJORTING-HANSEN ${ }^{15}$, 16, em dois trabalhos seqüenciais, analisaram clínica, radiográfica e microscopicamente dentes humanos reimplantados. Os resultados incluíram, desde dentes com a raiz íntegra, até dentes com grandes lacunas de reabsorção, bem como anquilose, formação de epitélio juncional longo e reparo do ligamento periodontal.

Em um trabalho de reimplante de dentes realizado em macacos, CAFFESSE; NASJLETI; CASTELLI ${ }^{32}$, em 1977, avaliaram os eventos ocorridos em um período de tempo maior. Após 2 anos, os autores observaram presença de fibras de tecido conjuntivo paralelas ao dente, anquilose, reabsorção radicular lateral e apical e algumas áreas de reparo. Aos 3 e 4 anos, verificaram extensas áreas de reabsorção dentinária, 
algumas com comunicação com o canal radicular e quase ausência de áreas reparadas.

Dessa forma, a anquilose e as reabsorções em diferentes tipos são as principais complicações que ocorrem em dentes avulsionados e reimplantados.

Ao contrário do osso que sofre reabsorção e aposição como um processo de remodelamento contínuo, as raízes dos dentes permanentes não apresentam esse mecanismo. A reabsorção dos dentes decíduos durante a exfoliação é considerada fisiológica (HAMMARSTRÖM; LINDSKOG $\left.{ }^{54}, 1985\right)$.

As reabsorções dentárias vêm sendo objeto de estudo por vários autores e, dessa forma, recebem classificações variadas. A reabsorção radicular externa, segundo HJORTING-HANSEN ${ }^{16}$, 1966, pode ser dividida em três tipos: reabsorção superficial, reabsorção inflamatória e reabsorção por substituição. Esta classificação é também aceita por outros autores ${ }^{12,13}$, 56.

- Reabsorção radicular de superficial: definida como um conjunto de pequenas cavidades superficiais restritas ao cemento. São vistas precocemente, geralmente uma semana após o reimplante (ANDREASEN ${ }^{7}$, 1980). Não havendo contaminação ou reação inflamatória persistente, entram em processo de reparo pela neoformação de cemento que, depositado naquelas cavidades, restabelecem 0 contorno radicular (ANDREASEN, ANDREASEN ${ }^{14}$, 1994). Quando essas lacunas se comunicam com áreas inflamadas ou contaminadas pelos produtos de necrose tecidual e bactérias, podem evoluir para reabsorção inflamatória (ANDREASEN ${ }^{11}, 1981$ ).

- Reabsorção radicular inflamatória: pode ser resultado de necrose do ligamento periodontal, oriunda de seu ressecamento (ANDREASEN $\left.{ }^{7}, 1980\right)$. A reabsorção de superfície, representada por áreas 
desprovidas de cemento, perde seu caráter transitório cedendo lugar à reabsorção do tipo inflamatória em dentes com necrose pulpar instalada e contaminação bacteriana, que são estímulos necessários para a sua progressão. Em alguns casos as lacunas de reabsorção são tão profundas que podem se comunicar com o canal radicular ${ }^{14,23,56,90,122 .}$

- Reabsorção radicular por substituição: é desencadeada após a anquilose dentária e seu mecanismo consiste na substituição progressiva de toda a estrutura radicular por tecido ósseo ${ }^{14,23,56,90,122 .}$

Quando um dente avulsionado é reimplantado depois de prolongado armazenamento em meio extrabucal a seco (ANDREASEN ${ }^{8}$, 1980) ou meio impróprio (CVEK et al. ${ }^{38}$, 1974; ANDREASEN $^{9}, 1981$; BLOMLÖF et al. ${ }^{28}$, 1983), pode ocorrer a anquilose alveolodentária. Esse evento se caracteriza pelo contato direto do dente com o osso alveolar devido à perda parcial ou completa do ligamento periodontal depois do reimplante dentário havendo, portanto, ausência de articulação entre o dente e o osso alveolar ${ }^{4}, 12,55,90,122$. Quando ocorre a necrose do ligamento periodontal, o osso neoformado ocupa o local deste e une-se, assim, à raiz ${ }^{23}$, 56, 79, 90 . Alguns autores descreveram, há algum tempo, a anquilose como sendo semelhante à reabsorção por substituição ${ }^{12}$. Os eventos, conforme HAMMARSTRÖM; BLOMLÖF; LINDSKOG ${ }^{53}$, 1989 e TRONSTAD ${ }^{122}$, 1988, são diferentes, uma vez que a anquilose consiste apenas na união do osso com raiz pela perda do ligamento periodontal, enquanto que a reabsorção por substituição, conseqüência de danos substanciais ao ligamento periodontal e cemento, caracteriza-se pela neoformação óssea em áreas de reabsorção de dentina ${ }^{53}$.

Clinicamente, o dente anquilosado não tem mobilidade, pode apresentar-se em infra-oclusão e, sob percussão, terá um som metálico ${ }^{90}$. A identificação da anquilose, radiograficamente, é difícil, mas a ausência do espaço do ligamento periodontal pode ser uma das evidências ${ }^{4}$. O dente anquilosado pode assim permanecer por tempo indeterminado, contudo, na maioria das vezes, o osso passa a reconhecer o elemento dentário como 
próprio, incorporando-o ao seu processo de remodelação contínua e substituindo-o totalmente por tecido ósseo ${ }^{4,53,122 .}$

As reabsorções dos dentes permanentes devem ser consideradas invariavelmente patológicas, uma vez que se caracteriza pela ausência de renovação dos tecidos dentários mineralizados ao contrário do que acontece no tecido ósseo, cuja renovação se faz constantemente, ou seja, é fisiológica (CONSOLARO $\left.{ }^{35}, 2002\right)$.

Devido à semelhança entre a morfologia, as propriedades enzimáticas e a função das células que reabsorvem dentina, cemento e osso, pode-se considerar que os processos de reabsorção dentária e óssea são semelhantes ${ }^{55,90}$. Assim, ao se caracterizar a reabsorção óssea, estarse-ia caracterizando também a dentária.

A reabsorção normal ou patológica dos tecidos mineralizados ocorre pela ação dos clastos interagindo-se com mediadores liberados localmente pelos osteoblastos e células semelhantes aos macrófagos, que se encontram próximas aos clastos. Os osteoblastos possuem receptores para mediadores locais e sistêmicos. A este conjunto, clastos, osteoblastos e macrófagos, denominamos unidade de reabsorção de tecido mineralizado ou unidade osteorremodeladora ou simplesmente BMU, abreviando-se do inglês bone remodeling unit, responsável pela reabsorção de tecido mineralizado (RODAN; MARTIN ${ }^{107}, 1981$ ).

Os osteoblastos e cementoblastos são células responsáveis pela formação do osso e cemento, respectivamente, revestem a superfície desses tecidos, preservando sua integridade (RODAN; MARTIN ${ }^{107}$, 1981). Entre aqueles dois tipos de células formadoras de tecido mineralizado, há uma diferença de receptores: os cementoblastos não possuem receptores para mediadores estimuladores da reabsorção, em especial o paratormônio (LINDSKOG et al. ${ }^{80}$, 1987). Isso talvez explique porque determinados hormônios como $\mathrm{PTH}$, vitamina $\mathrm{D}$ e esteróides não induzem a reabsorção dentária e, também, por que os dentes não se remodelam como o osso ${ }^{59}$. A 
reabsorção radicular tem como pressuposto para o seu desencadeamento a perda de seu recobrimento pelos cementoblastos, os guardiões da integridade da superfície radicular que não permitem ao dente participar do turnover ósseo (HAMMARSTÖM; BLÖMLOF; LINDSKOG ${ }^{53}$, 1989).

Os clastos, por outro lado, são células envolvidas no processo de destruição de tecido mineralizado. A diferença estrutural, organizacional e funcional entre os dentinoclastos, cementoclastos e osteoclastos são insignificantes, ainda que detectáveis (PIERCE ${ }^{102}$, 1989; HAMMARSTRÖN; LINDSKOG $^{54}$, 1985), por isso essas células podem ser referidas simplesmente como clastos (CONSOLARO ${ }^{35}$, 2002). Apresentam-se como células gigantes, multinucleadas ${ }^{22,55,90}$, medindo cerca de 50 a 100 $\mu \mathrm{m}$, formadas a partir da fusão de precursores mononucleados derivados da medula óssea ${ }^{13,22,55,90,102}$. Seu citoplasma é basofílico e granular, com vacúolos de tamanhos variados. São células polarizadas, apresentando dois pólos: apical e basolateral. No pólo basolateral, estão localizadas as organelas responsáveis pela produção de enzimas e substâncias que participam do processo reabsortivo. Já no pólo apical, observa-se a zona clara, a zona de selamento e a borda pregueada ou membrana apical ${ }^{22}$.

O pólo apical está voltado para a superfície mineralizada a ser reabsorvida. A zona clara é caracterizada por uma área livre de organelas onde há somente filamentos de actina, formando tufos perpendiculares ao tecido duro que, juntamente com a zona de selamento, une-se à superfície a ser reabsorvida ${ }^{22}$. O clasto unido ao tecido mineralizado forma um compartimento de reabsorção também denominado lacuna de Howship ${ }^{22,} 55$, 90

Quando ocorre uma avulsão dentária e posterior reimplante, por exemplo, instala-se um processo inflamatório na região do ligamento periodontal. No exsudato inflamatório é liberada grande quantidade de produtos como os do ácido araquidônico, citocinas, fatores de crescimento, lipopolissacarídeos e óxido nítrico. Todos esses produtos são importantes mediadores locais indutores de osteoclasia. O principal deles, a plasmina, 
interage com os osteoblastos liberando a colagenase que promove a perda total do osteóide aposto na superfície óssea (PIERCE $\left.{ }^{102}, 1989\right)$. Assim, os cristais de hidroxiapatita ficam expostos e parecem exercer um efeito quimiotático para os clastos. A migração dos clastos e seu acoplamento na superfície desnuda da raiz caracterizam a instalação da BMU (CONSOLARO $\left.{ }^{35}, 2002\right)$.

A atividade dos clastos pode ser paralisada elevando-se o $\mathrm{pH}$ do micro-ambiente referido. Nos procedimentos clínicos, o hidróxido de cálcio, na forma de pasta, é levado ao canal radicular com a finalidade de tornar básico $\mathrm{o} \mathrm{pH}$ do meio, de modo que a reabsorção radicular externa inflamatória seja paralisada, permitindo que o processo de reparo ocorra nas estruturas afetadas pela reabsorção $\left(\right.$ CVEK $^{37}$, 1973; TRONSTAD ${ }^{122}$, 1988; TRONSTAD et al. $\left.{ }^{123}, 1981\right)$.

\subsection{TERAPÊUTICA ENDODÔNTICA}

Quase todos os dentes avulsionados terão que ser submetidos ao tratamento endodôntico. O estádio de formação radicular, a contaminação microbiana e o tempo extra-alveolar são fatores a serem considerados no momento de se decidir pela intervenção endodôntica ou não (ANDREASEN $^{11}$, 1981; DIANGELIS; BAKLAND $\left.{ }^{40}, 1999\right)$.

Quando o forame apical estiver fechado, o tratamento endodôntico deverá ser sempre realizado profilaticamente, uma vez que a necrose pulpar pode ser prevista. A necrose do tecido pulpar e as suas toxinas poderão atingir as células presentes na superfície radicular, via túbulos dentinários, contribuindo assim para o desencadeamento da reabsorção inflamatória (ANDREASEN; ANDREASEN ${ }^{14}$, 1994).

Em 1981, ANDREADEN ${ }^{9}$ verificou em reimplantes realizados em macacos que, quando o tempo extra-alveolar for prolongado e o tratamento 
endodôntico não for realizado, haverá o desenvolvimento de reabsorção radicular.

O momento correto para a instituição do tratamento endodôntico, ainda hoje, é motivo de discussões entre os autores ${ }^{116}$. ANDREASEN; HJORTING-HANSEN ${ }^{16}$ (1966) ressaltaram que o tratamento endodôntico deveria ser deixado para depois do reimplante, pois a revascularização pulpar poderia ocorrer. Já, $\operatorname{DEEB}^{39}$ (1971) afirmou que, quando o tempo extrabucal for maior que 2 horas, a terapia endodôntica deverá ser realizada antes do reimplante.

A AMERICAN ASSOCIATION OF ENDODONTICS ${ }^{2}, 1994$, recomendou que se o dente permanecer por mais de 1 hora fora do alvéolo, o tratamento endodôntico deverá ser realizado antes do reimplante; já, se o tempo não exceder a 1 hora, deve-se considerar a possibilidade de revascularização em dentes com rizogênese incompleta e, em dentes com ápice fechado, faz-se a endodontia entre 7 e 14 dias após o reimplante. TROPE $^{124}$, em 2002, considerou que, se o reimplante for feito em dentes com ápices fechados, independentemente do tempo extra-alvelar, o tratamento endodôntico deverá ser feito, no máximo, após 7 a 10 dias do reimplante, para que a polpa necrosada esteja ausente de infecção, o que facilitaria o reparo. TROPE et al. ${ }^{126}$, em 1995, alertaram para o fato de que a demora para a remoção pulpar favoreceria o aparecimento da reabsorção inflamatória, uma vez que as bactérias presentes no canal radicular chegariam à superfície radicular via túbulos dentinários. Logo, o tratamento endodôntico deverá ser realizado em até 10 dias do reimplante.

Nos dentes com rizogênese incompleta cujos reimplantes ocorreram em até três horas após a avulsão, recomenda-se 0 acompanhamento clínico e radiográfico criterioso do caso, pois há chances de ocorrer a revascularização pulpar. Devem ser feitos controles radiográficos duas e três semanas após o reimplante uma vez que evidências radiográficas de reabsorção radicular podem ser vistas nesse período. Caso isso ocorra, a terapia endodôntica deve ser instituída 
imediatamente com a colocação de medicação contendo hidróxido de cálcio no canal radicular com o objetivo de controlar a reabsorção inflamatória, além de promover a apicificação (ANDREASEN; ANDREASEN ${ }^{14}, 1994$ ).

Tanto para dentes com rizogênese completa ou dentes com formação radicular incompleta, mas com necrose pulpar, o tratamento endodôntico consiste na remoção da polpa dentária seguida da utilização de curativos intracanais. O curativo intracanal tem como objetivos eliminar a contaminação microbiana ${ }^{117}$ e limitar a ocorrência da reabsorção radicular inflamatória ${ }^{123}$.

Em 1992, TROPE et al. ${ }^{125}$ analisaram o reparo de dentes de cães reimplantados, tendo seus canais infectados ou não, e tratados com hidróxido de cálcio, a curto e longo prazo, 1 e 8 semanas, respectivamente. Os resultados levaram os autores a concluir que o tratamento a longo prazo com o hidróxido de cálcio, em dentes reimplantados e tratados endodonticamente em até 14 dias, não é necessário; já que o uso do curativo por um período mais curto mostrou resultados semelhantes.

Para períodos superiores a 14 dias, o tratamento a longo prazo com hidróxido de cálcio permite que o profissional só conclua o tratamento endodôntico quando o espaço do ligamento periodontal intacto for constatado. O curativo deverá ser trocado a cada três meses até o período de 6-24 meses, dependendo do caso. Toda vez que o tratamento endodôntico for instituído após mais que duas semanas da ocorrência do trauma, esse tratamento a longo prazo com o hidróxido de cálcio deverá ser usado (TROPE ${ }^{124}, 2002$ ).

Em 1981, TRONSTAD et al. ${ }^{123}$ verificaram mudanças de $\mathrm{pH}$ nos tecidos dentários, quando do uso do hidróxido de cálcio intracanal. Este foi capaz de influenciar favoravelmente nos sítios de reabsorção, inativando clastos e estimulando o reparo. 
BARRETT; KENNY ${ }^{23}$, em 1997, em um trabalho de revisão de literatura visando estabelecer um protocolo de tratamento de dentes reimplantados, contra-indicaram o tratamento com hidróxido de cálcio intracanal a longo prazo, quando o tempo extra-alveolar for inferior a 30 minutos.

TROPE ${ }^{124}$, em 2002, salientaram que o hidróxido de cálcio é a droga de escolha para a prevenção e tratamento da reabsorção inflamatória, porém não é o único medicamento recomendado para esses casos. Outras substâncias como, por exemplo, a pasta Ledermix® e a calcitonina podem ser indicadas.

\subsection{ALENDRONATO: POTENTE INIBIDOR DA ATIVIDADE OSTEOCLÁSTICA}

O alendronato é um composto aminobifosfonado, uma potente droga usada no tratamento da osteoporose, doença de Paget e outras desordens de reabsorção óssea (KELLER; FLIESLER ${ }^{68}$, 1999).

Tem sido mostrado que os bifosfonatos têm um potente efeito inibitório da reabsorção óssea pela inibição da atividade dos osteoclastos (MASARACHIA et al. $^{82}$, 1996). O alendronato, particularmente, age induzindo a apoptose dos osteoclastos, células reabsorvedoras de osso (HUGHES et al. $\left.{ }^{61}, 1995\right)$.

O alendronato liga-se aos cristais de hidroxiapatita no osso e se une, preferencialmente, às superfícies ósseas reabsorvidas, particularmente àquelas que estão sofrendo atividade de reabsorção osteoclástica (SELBY ${ }^{113}$, 1996). A afinidade do alendronato por fosfato de cálcio e sua forte ligação à hidroxiapatita leva à sua rápida incorporação ao esqueleto $\left(\right.$ FLEISCH ${ }^{47}$, 1993). Uma vez unido ao osso, o alendronato é retido por prolongados períodos de tempo. Tem sido estimado que o tempo de vida 
para eliminá-lo do esqueleto em humanos é da ordem de dez anos (KANIS et al. $\left.{ }^{66}, 1995\right)$.

O mecanismo de inibição osteoclástica tem sido atribuído a um decréscimo da atividade osteoclástica com efeitos mínimos (BREUIL ${ }^{29}$, 1998); à interferência dos receptores dos osteoclastos com proteínas específicas da matriz óssea (COLUCCI, et al. ${ }^{34}$, 1998); à produção de um inibidor osteoclástico por osteoblastos que reduzem o tempo de vida e/ou o número de osteoclastos diferenciados (VITTE et al. ${ }^{128}$, 1996) e à paralisação da reabsorção pela interferência com o bordo pregueado dos osteoclastos (SATO et al. $\left.{ }^{111}, 1991\right)$.

Apesar dos poucos trabalhos existentes na literatura utilizando-se o alendronato para tratamento das reabsorções radiculares após reimplante de dentes avulsionados, foi mostrado que o alendronato age de maneira semelhante ao flúor no tratamento da reabsorção radicular, quando usado topicamente (LEVIN et al. ${ }^{75}$, 2001).

SOMMERCORN et al. ${ }^{121}$, em 2000, investigaram o uso do alendronato na formação de nova dentina in vitro. Ápices imaturos de prémolares e molares foram mantidos em meio de cultura de tecidos com e sem alendronato por 60 dias. Os resultados mostraram que o grupo contendo alendronato cresceu $57,15 \%$ mais do que o que não o continha. Os autores concluíram que o alendronato foi efetivo na aceleração da formação de dentina in vitro.

KUM et al. ${ }^{70}$, em 2003, avaliaram o efeito inibitório do alendronato e taurine sobre a diferenciação de osteoclastos induzida por Porphyromonas gingivalis in vitro e concluíram que ambas as substâncias apresentam tal capacidade.

CORREIA et al. ${ }^{36}$, em 2004, analisaram a citotoxicidade do alendronato de sódio sobre fibroblastos do ligamento periodontal humano em cultura celular e demonstraram que a substância, em contato direto com 
fibroblastos humanos, é citotóxico nas concentrações superiores a $10^{-7} \mathrm{M}$ inibindo, inclusive, o crescimento celular de forma proporcional ao aumento da sua concentração.

MORI et al. ${ }^{86}$, em 2005, estudaram a capacidade de difusão da solução de alendronato através dos túbulos dentinários com o objetivo de avaliar, posteriormente, o efeito dessa substância como medicação intracanal. Os autores constataram que a solução de alendronato foi capaz de se difundir através dos túbulos dentinários e, conseqüentemente, poder ser usada como agente terapêutico intracanal em dentes com reabsorção radicular externa. 
3 Proposição 


\section{PROPOSIÇÃO}

Comparar o efeito da aplicação tópica do alendronato de sódio na superfície radicular de dentes de extraídos de ratos e reimplantados tardiamente, considerando dois períodos de permanência extra-alveolar a seco, com dentes extraídos e reimplantados imediatamente, sem nenhum tratamento da superfície radicular. 
4 Material
e Métodos 


\section{MATERIAL E MÉTODOS}

Foram utilizados 54 ratos (Rattus, norvegicus, albinus, Wistar) machos, com peso corporal entre 250 e 300 gramas, cujos incisivos superiores direitos foram extraídos, simulando uma avulsão dentária.

Para as intervenções cirúrgicas, os animais receberam como medicação pré-anestésica o Anasedan (Agribrands do Brasil Ltda, Paulínia$\mathrm{SP}$, Brasil) na dosagem de $15 \mathrm{mg}$ por $\mathrm{kg}$ de peso, por via intramuscular na face posterior da coxa. Em seguida, foram anestesiados com Dopalen (Agribrands do Brasil Ltda, Paulínia-SP, Brasil) na dosagem de $25 \mathrm{mg}$ por $\mathrm{kg}$ de peso associado ao Anasedan na dosagem de $10 \mathrm{mg}$ por $\mathrm{kg}$ de peso na mesma seringa, também por via intramuscular na mesma região. Após a anestesia, foram realizadas a anti-sepsia da porção anterior da maxila (Figura 1) com Chlorohex (Ceras Johnson Ltda, Jacarepaguá-RJ, Brasil) (solução de clorexidina a $2 \%$ ), sindesmotomia (Figura 2), luxação e extração do incisivo superior direito (Figuras 3 e 4), simulando uma avulsão dentária. Para os procedimentos de sindesmotomia, luxação e extração dentária foram utilizados instrumentos cirúrgicos especialmente adaptados (Figuras 5 e 6), cedidos pela Disciplina de Cirurgia da Faculdade de Odontologia de Bauru-USP. 


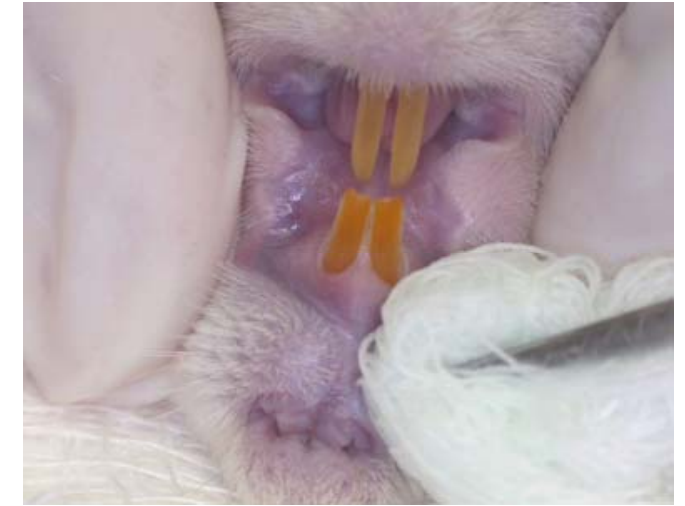

FIGURA 1 - Anti-sepsia da região anterior da maxila

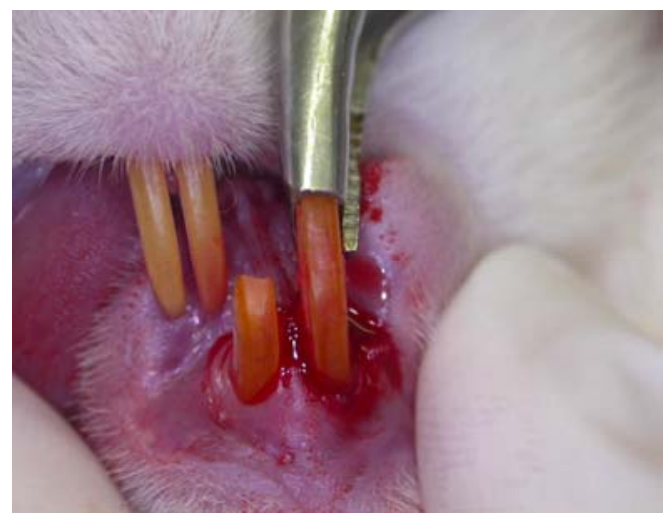

FIGURA 3 - Luxação e extração do incisivo superior direito

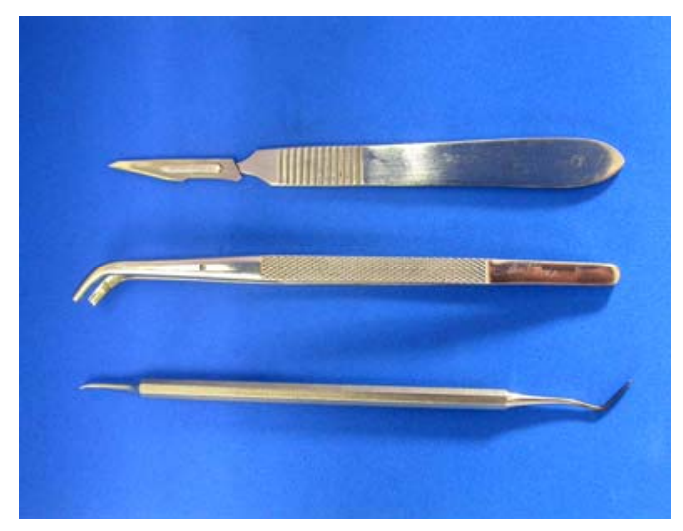

FIGURA 5 - Instrumentos cirúrgicos

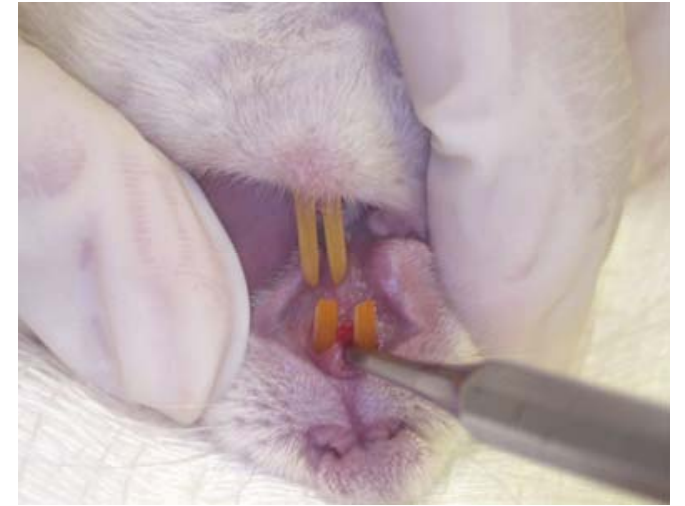

FIGURA 2 - Sindesmotomia do incisivo superior direito

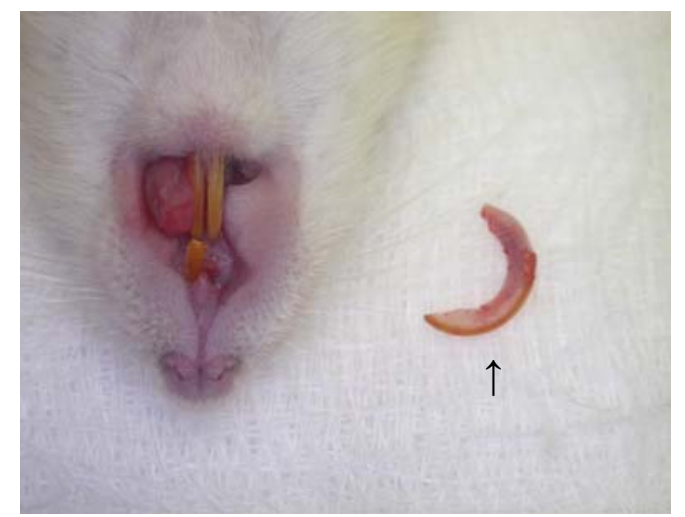

FIGURA 4 - Incisivo superior direito extraído ( $\uparrow)$

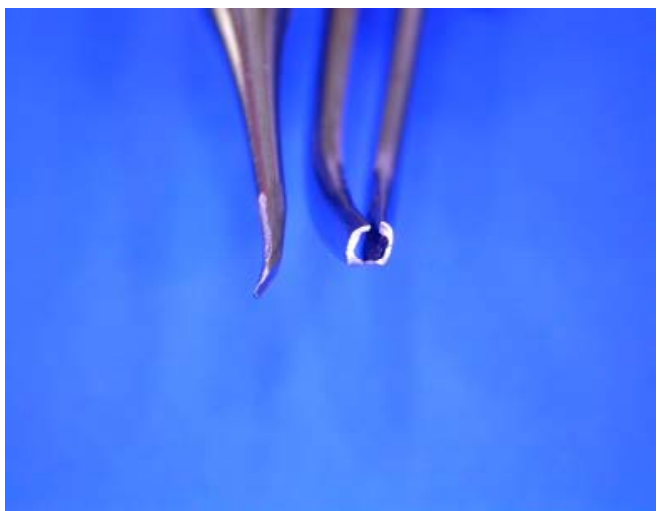

FIGURA 6 - Instrumentos cirúrgicos adaptados (parte ativa) 
Os dentes extraídos permaneceram expostos em meio ambiente, presos através de suas coroas em uma lâmina de cera rosa $n^{\circ} 7$ (Figura 7), por um tempo pré-estabelecido para cada grupo experimental (15, 30 e 60 minutos), para que ocorresse o ressecamento do ligamento periodontal, simulando as condições nas quais os dentes avulsionados são, geralmente, levados aos consultórios odontológicos.

Decorridos tais tempos, os dentes tiveram a papila dentária excisionada com uma lâmina de bisturi n ${ }^{\circ}$ 11(B-D Becton Dickinson Indústrias Cirúrgicas Ltda, Juiz de Fora-MG, Brasil) para a exposição do canal radicular. A polpa foi removida, via retrógrada, empregando-se uma lima Flexofile \#15 (Dentsply-Maillefer Instruments S.A., Ballaigues-Suíça), ligeiramente pré-curvada (Figura 8). A irrigação do canal radicular foi feita com soro fisiológico a 0,9\% (Figura 9) (JP Indústria Farmacêutica S.A., Ribeirão Preto-SP, Brasil) e a aspiração com uma seringa tipo Luer Look e cânula $n^{\circ} 25$ x 6 (B-D Becton Dickinson Indústrias Cirúrgicas Ltda, Juiz de Fora-MG, Brasil) acoplada a ela. Esses dentes, divididos em três grupos conforme o tempo de permanência extra-alveolar, receberam tratamento específico para cada um dos grupos experimentais:

- Grupo I (tempo de permanência extra-alveolar de 15 minutos): seus canais radiculares foram secos com cones de papel esterilizados (Figura 10), preenchidos com pasta de hidróxido de cálcio $\left(\mathrm{CALEN}^{\circledR}\right)$ (Figura 11) (S.S. White Artigos Dentários Ltda, Rio de Janeiro-RJ, Brasil) e, em seguida, foram reimplantados nos seus respectivos alvéolos (Figuras 12 e 13), simulando o reimplante imediato. 


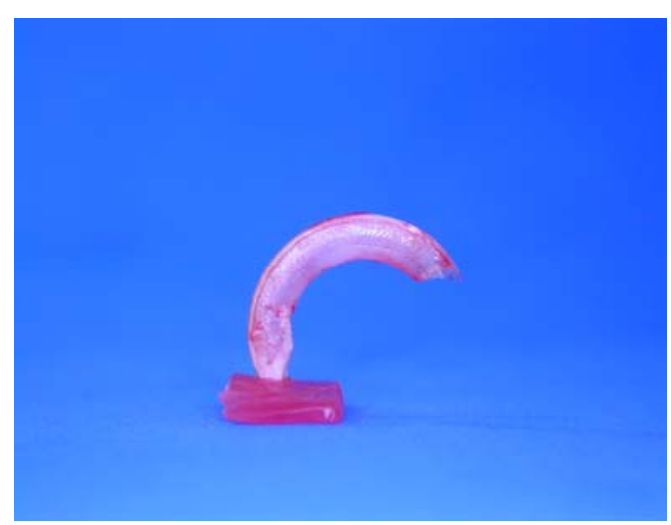

FIGURA 7 - Incisivo extraído exposto ao meio ambiente

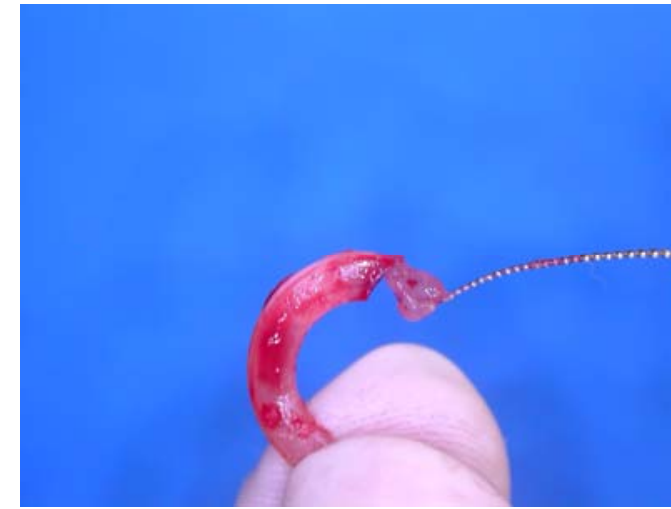

FIGURA 8 - Remoção da polpa, via retrógrada

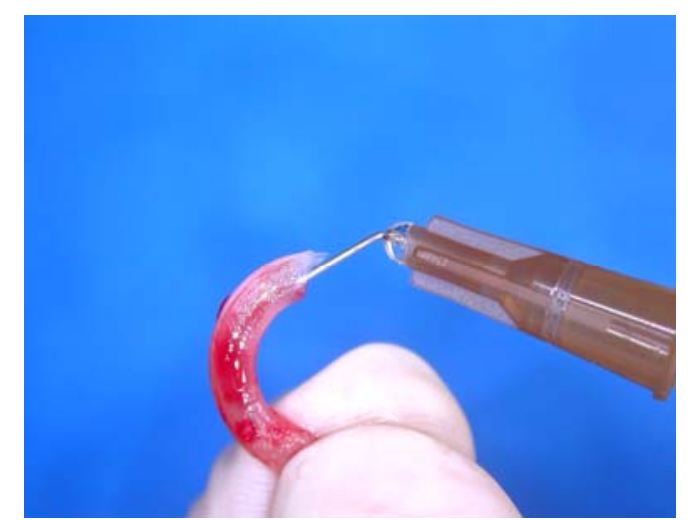

FIGURA 9 - Irrigação do canal radicular com soro fisiológico

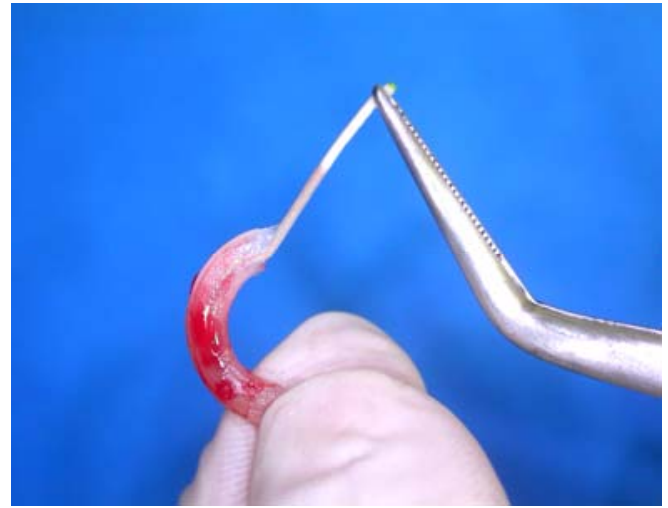

FIGURA 10 - Secagem do canal radicular com cones de papel esterilizados

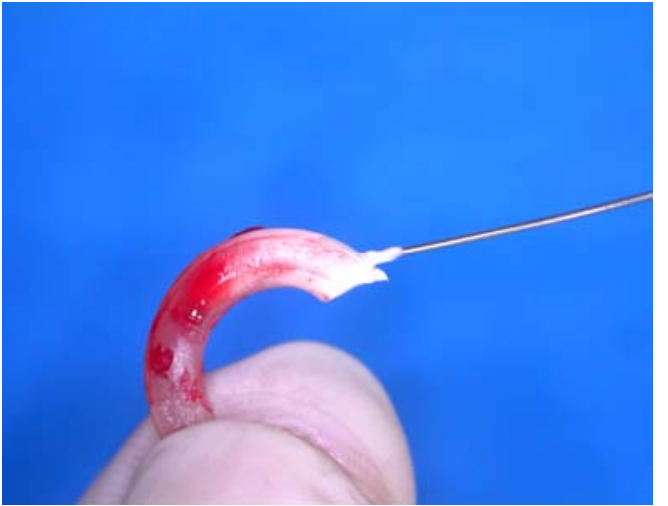

FIGURA 11 - Preenchimento do canal radicular com pasta de hidróxido de cálcio $\left(\right.$ CALEN $\left.^{\circledR}\right)$ 
- Grupos II e III (tempo de permanência extra-alveolar a seco 30 e 60 minutos, respectivamente): Após esses tempos, os dentes receberam tratamento de superfície radicular (Figura 14). Cada dente foi imerso em $50 \mathrm{ml}$ de hipoclorito de sódio a 1\% (Farmácia Specífica, Bauru-SP, Brasil), por 30 minutos, objetivando a remoção do ligamento periodontal ressecado. Em seguida, lavado por imersão em $50 \mathrm{ml}$ de soro fisiológico a 0,9\% por 5 minutos e depois imerso em solução de $50 \mathrm{ml}$ de alendronato de sódio a 3,2mg/l (Farmácia Specífica, Bauru$\mathrm{SP}$, Brasil) por 10 minutos. Os canais radiculares foram aspirados, secos e preenchidos com pasta de hidróxido de cálcio $\left(\mathrm{CALEN}^{\circledR}\right)$ e reimplantados nos seus respectivos alvéolos, simulando o reimplante tardio.

A pasta utilizada para o preenchimento do canal radicular é composta de hidróxido de cálcio associada ao veículo polietilenoglicol 400, óxido de zinco p.a. e colofônia, conhecida comercialmente por CALEN ${ }^{\circledR}$, e introduzida no canal radicular com o auxílio da seringa ML (S.S. White Artigos Dentários Ltda, Rio de Janeiro-RJ, Brasil), própria para o medicamento.

A solução de alendronato de sódio, aplicada na superfície radicular dos dentes dos grupos II e III, é um composto bifosfonato cuja composição foi a seguinte $3,2 \mathrm{mg}$ de alendronato de sódio e água destilada qsp 11.

Não foi realizada nenhuma contenção nos dentes reimplantados e todos os animais receberam dose única de 20.000 U.I. de penicilina $G$ benzatina (Eurofarma Laboratórios Ltda, São Paulo-SP, Brasil), por via intramuscular, na parte posterior da coxa traseira direita, logo após a reimplantação do dente extraído. 


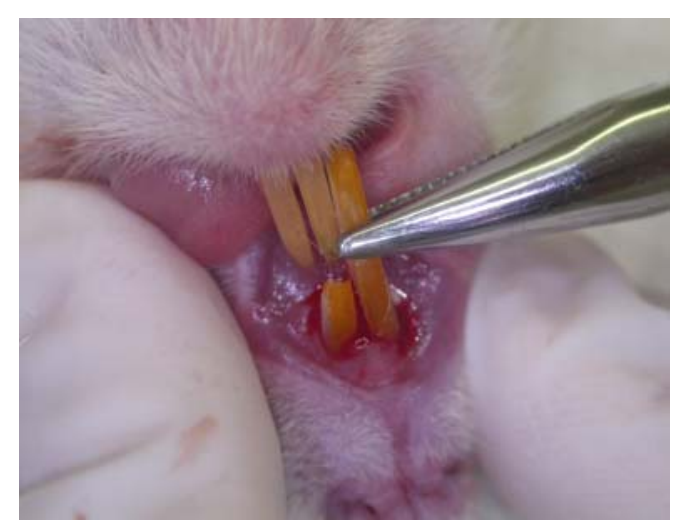

FIGURA 12 - Reimplante do incisivo superior no alvéolo

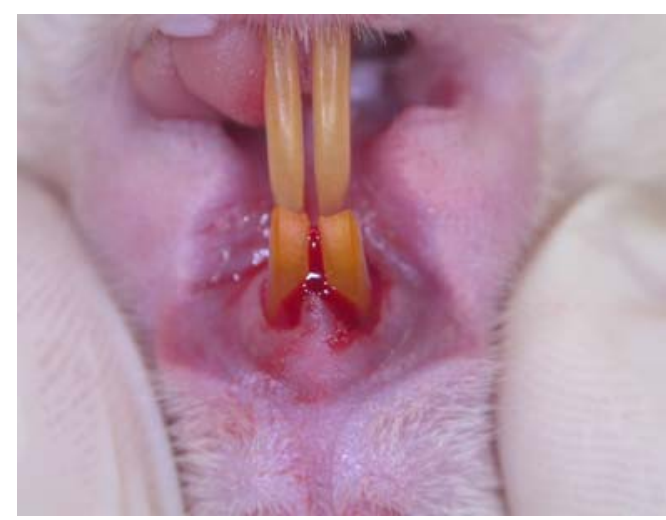

FIGURA 13 - Incisivo superior devidamente reposicionado

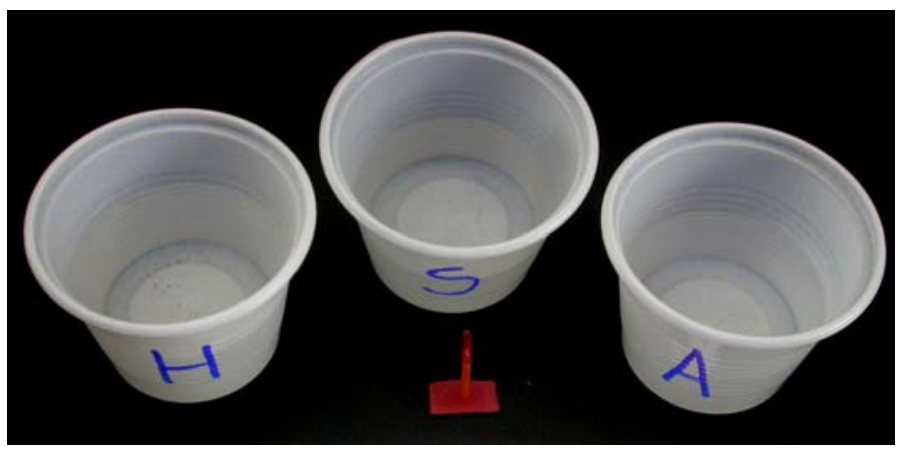

FIGURA 14 - Recipientes contendo soluções para tratamento da superfície radicular: $\mathrm{H}$ - Hipoclorito de sódio a $1 \%, \mathrm{~S}-$ Soro fisiológico a $0,9 \%$, A - Alendronato de sódio a 3,2mg/l 
Os animais foram alimentados normalmente antes e após o experimento, exceto nas primeiras doze horas pré e pós-operatórias. Após o período de doze horas, pós-operatórias, os animais se alimentaram com ração sólida triturada até se completar setenta e duas horas. Depois desse tempo a alimentação voltou a ser normal.

Transcorridos os períodos de 15, 60 e 90 dias do reimplante, seis animais de cada grupo foram mortos por dose excessiva de anestésico. A maxila foi separada da mandíbula e, com o emprego de uma lâmina de micrótomo (Leica Microsystems Nussloch GmbH, Germany), fez-se um corte na região do molar mais posterior e na linha mediana, separando a maxila direita da esquerda, possibilitando a obtenção da hemimaxila que continha o dente reimplantado.

As peças com o dente reimplantado foram fixadas em formol neutro a $10 \%$ (Merck KGaA, Germany) por sete dias e, então, descalcificadas em solução de EDTA a 4,7\%, pH 7,0 (Merck KGaA, Germany). Considerou-se a peça descalcificada quando nela pudesse ser introduzida uma agulha fina sem qualquer tipo de resistência. A seguir, foram submetidas ao processamento histotécnico e incluídas em parafina, sendo 27 peças orientadas de forma a obter cortes no sentido transversal (terços cervical, médio e apical) e 27 peças no sentido longitudinal. As peças submetidas ao corte transversal foram primeiramente seccionadas, para que depois os segmentos fossem incluídos e devidamente identificados. Os cortes semi-seriados foram realizados na espessura de 05 micrometros e posteriormente corados com hematoxilina e eosina para estudo em microscópio de luz.

A análise microscópica da estrutura dentária e parendodôntica levou em consideração os seguintes aspectos:

- Orientação e estrutura do tecido conjuntivo adjacente à raiz; 
- Reação inflamatória: tipo de infiltrado e intensidade (discreta, moderada ou intensa);

- Anquilose dentoalveolar;

- Reabsorção dentária: tipo, extensão, localização (terços cervical, médio e apical), em atividade ou reparada;

- Recomposição do ligamento periodontal. 
5 Resultados 


\section{RESULTADOS}

A análise microscópica tanto dos cortes longitudinais quanto transversais de cada grupo, será apresentada de forma descritiva.

5.1 GRUPO I: Tempo de permanência extra-alveolar de 15 minutos

\section{Período de 15 dias}

Cortes longitudinais

Na superfície radicular, em sua maior parte, havia tecido conjuntivo neoformado, à guisa de ligamento periodontal (Figura 15), com aspecto de normalidade, mantendo o espaço entre a superfície da raiz e o osso alveolar (Figura 16). Nos terços médio e apical havia alguns focos de reabsorção radicular e, nas proximidades do ápice, notou-se a presença discreta de neoformação óssea em íntimo contato com a superfície da raiz, caracterizando a anquilose, resquícios de pasta medicamentosa e uma faixa de necrose de coagulação com aspecto eosinofílico bem definido. Em contato com essa massa necrótica, foram observados focos de reação inflamatória com grande quantidade de polimorfonucleares neutrófilos em conjunto com macrófagos, células gigantes multinucleadas esparsas, além de exuberante tecido de granulação que se estendia até o fundo de alvéolo.

\section{Cortes transversais}

Terço cervical

O ligamento periodontal apresentou-se isento de células inflamatórias assumindo, em geral, uma disposição paralela à superfície radicular, exibindo segmentos de reinserção perpendicular (Figura 17). 
Terço médio

O ligamento periodontal assumiu, em alguns pontos, uma disposição paralela à superfície radicular bem mais definida do que aquela observada no terço cervical. A incidência de lacunas de reabsorção radicular foi maior e, apesar de pequenas, já atingiam dentina, podendo-se notar a presença de clastos no seu interior (Figura 18).

Terço apical

O ligamento periodontal, também isento de células inflamatórias, apresentou-se reinserido à raiz. A neoformação óssea, em alguns pontos, estava aderida à superfície radicular, sugerindo o fenômeno da anquilose em evolução, concomitante à presença de pequenas lacunas de reabsorção invadindo a estrutura dentinária (Figura 19). 


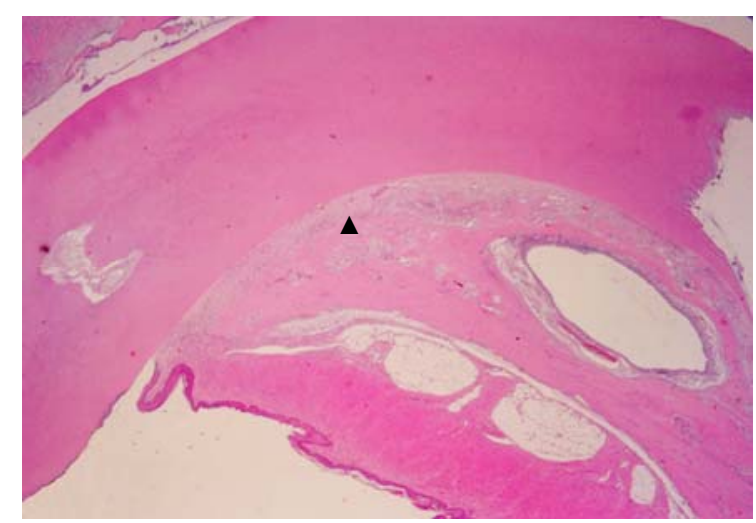

FIGURA 15 - Corte longitudinal. Grupo I, 15 dias. Vista geral da superfície radicular com tecido conjuntivo neoformado, semelhante ao ligamento periodontal ( $\mathbf{\Lambda})$. Objetiva 2,5X

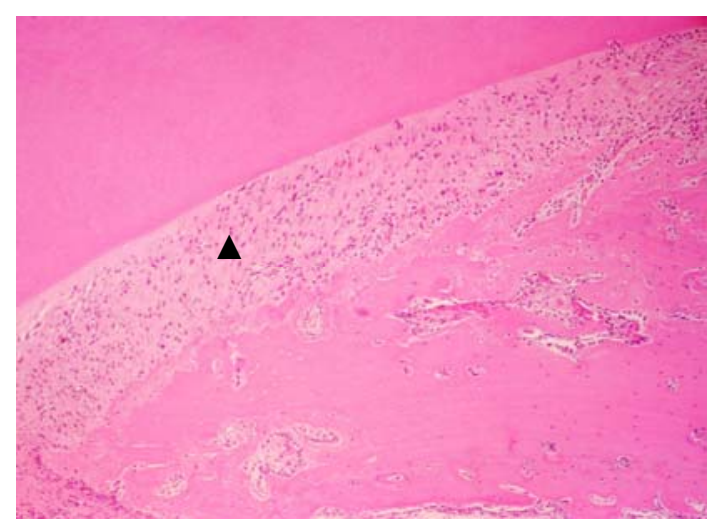

FIGURA 16 - Corte longitudinal. Grupo I, 15 dias. Reinserção perpendicular das fibras do ligamento periodontal $(\mathbf{\Delta})$. Objetiva 10X

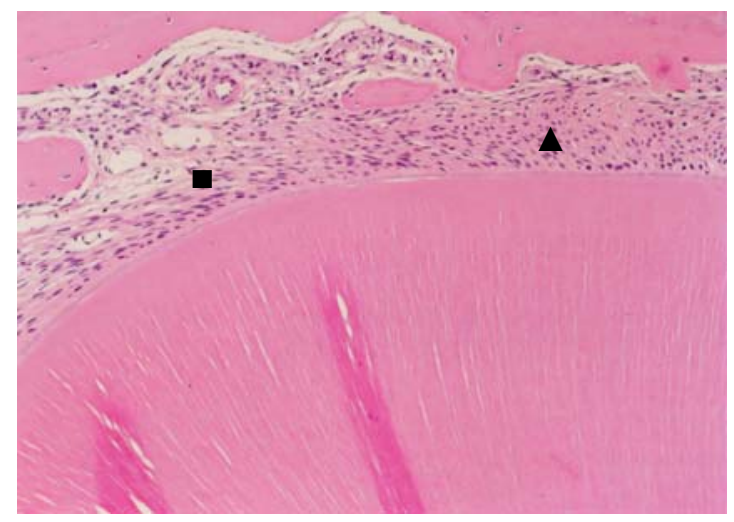

FIGURA 17 - Corte transversal. Grupo I, 15 dias. Reinserção perpendicular $(\mathbf{\Lambda})$ e paralela $(\mathbf{\square})$ do ligamento periodontal. Objetiva $25 \mathrm{X}$

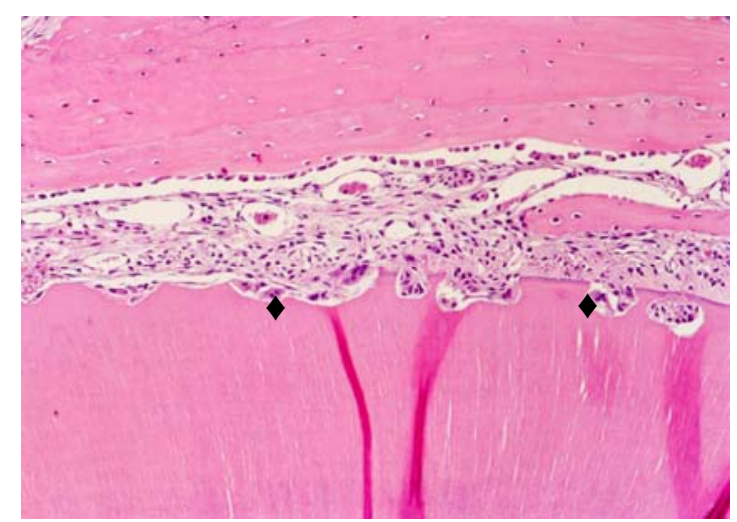

FIGURA 18 - Corte transversal. Grupo I, 15 dias. Lacunas de reabsorção inflamatória com presença de clastos ( $\bullet$. Objetiva 25X

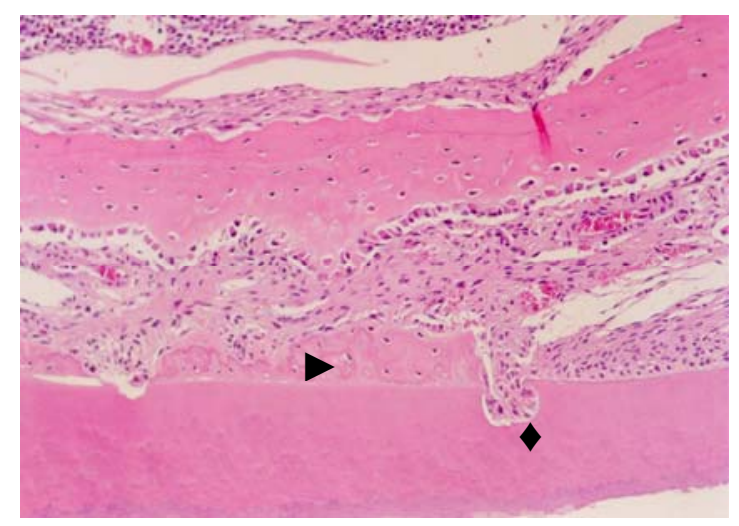

FIGURA 19 - Corte transversal. Grupo I, 15 dias. Presença de neoformação óssea $(\triangleright)$ e lacunas de reabsorção (४). Objetiva 25X 


\section{Período de 60 dias}

Cortes longitudinais

Ao longo da superfície radicular, principalmente nos terços médio e apical, observou-se a predominância do fenômeno da anquilose (Figura 20), presença de reabsorção por substituição, bem como a inflamatória comunicante e clastos (Figura 21).

Cortes transversais

Terço cervical

Esses cortes demonstraram tentativa de restabelecimento do ligamento periodontal, porém as fibras não assumiram o aspecto radial, dispondo-se paralelamente à superfície radicular revestida por cemento, que em alguns pontos apresentou-se mais espesso, reparando áreas de dentina reabsorvida. Em outro segmento dessa superfície radicular houve pontos de anquilose e reabsorção por substituição de pouca profundidade.

Terço médio

Observou-se em quase toda a sua extensão um processo de anquilose denotando já algumas áreas de reabsorção por substituição, bem como áreas de neoformação do ligamento periodontal, cuja estruturação dispunha-se paralela à superfície radicular.

Terço apical

Predomínio do processo de anquilose com algumas lacunas de reabsorção inflamatória. 


\section{Período de 90 dias}

Cortes longitudinais

Esse período revelou eventos reabsortivos mais intensos ao longo da superfície radicular, do tipo inflamatório comunicando-se com a luz do canal radicular (Figura 22), sobretudo nos terços médio e apical. Alguns espécimes desse grupo demonstraram, concomitantemente, extensas áreas de anquilose exibindo alguns segmentos de reabsorção por substituição (Figura 23). Por outro lado, intercalando-se com os eventos descritos, haviam espaços periodontais preservados com neoformação de ligamento periodontal, porém disposto paralelamente à superfície radicular.

\section{Cortes transversais}

Terço cervical

Presença de áreas de reabsorção inflamatória de profundidade moderada, alternadas com pequenos focos de reabsorção por substituição, anquilose (Figura 24) e áreas de ligamento periodontal neoformado.

Terço médio

Presença de reabsorção do tipo inflamatória comunicante, contendo tecido de granulação com infiltrado inflamatório mononuclear.

Terço apical

Reabsorção do tipo inflamatória comunicante com exuberante tecido de granulação, infiltrado mononuclear e, na periferia da dentina reabsorvida, a presença de clastos. 


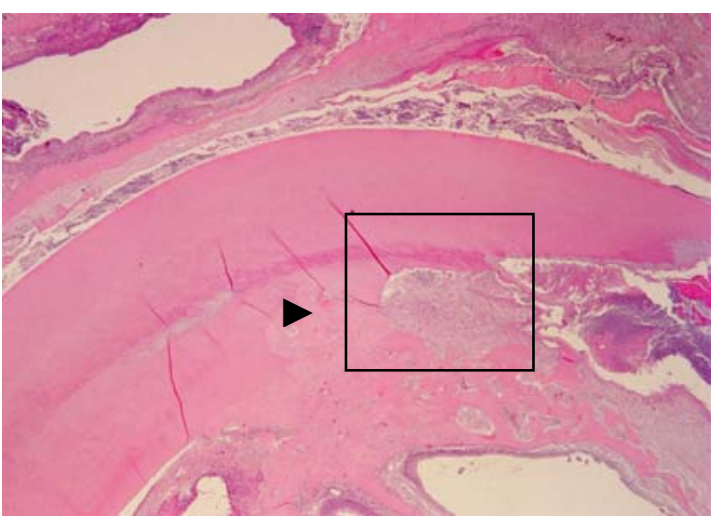

FIGURA 20 - Corte longitudinal. Grupo I, 60 dias. Fenômeno da anquilose $(\triangleright)$. Objetiva $2,5 \mathrm{X}$

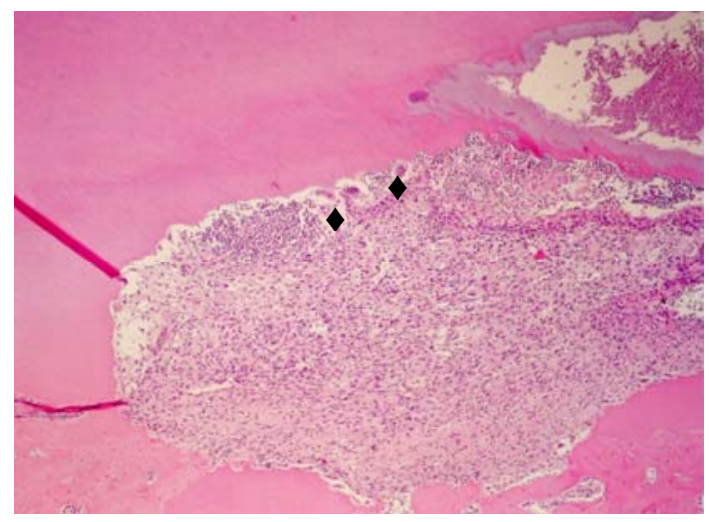

FIGURA 21 - Corte longitudinal, grupo I, 60 dias. Reabsorção inflamatória comunicante com presença de clastos ( $\downarrow$ ). Objetiva 10X

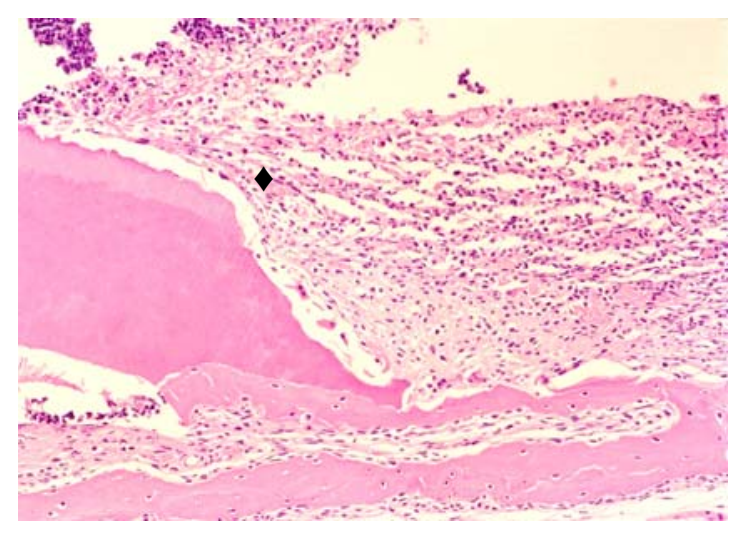

FIGURA 22 - Corte longitudinal. Grupo I, 90 dias. Reabsorção inflamatória comunicante ( $($ ). Objetiva $25 X$

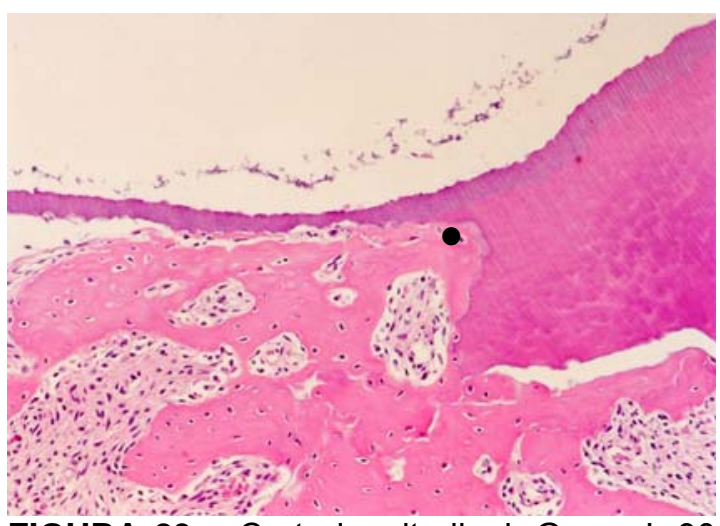

FIGURA 23 - Corte longitudinal. Grupo I, 90 dias. Reabsorção por substituição intensa $(\bullet)$. Objetiva 25X

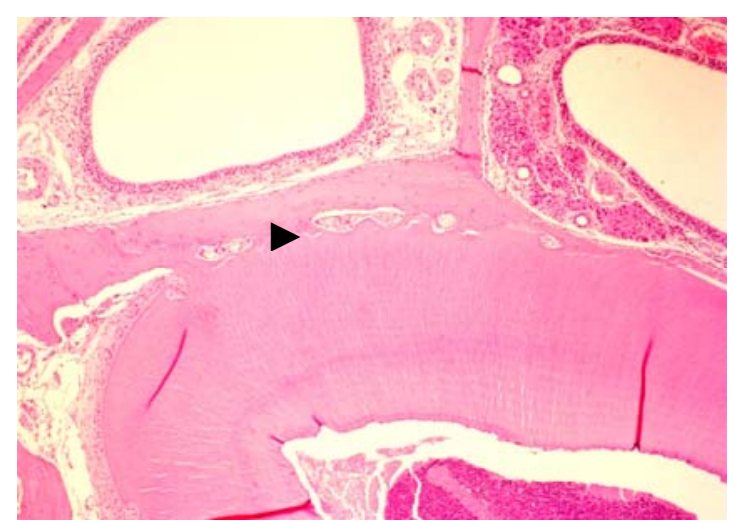

FIGURA 24 - Corte transversal. Grupo I, 90 dias. Anquilose dento-alvolar $(\triangleright)$. Objetiva $10 \mathrm{X}$ 
5.2 GRUPO II: Tempo de permanência extra-alveolar a seco de 30 minutos

\section{Período de 15 dias}

Cortes longitudinais

Nos terços cervical e médio, observou-se o restabelecimento do ligamento periodontal, com alternância de reinserção perpendicular (Figura 25) e paralela (Figura 26) à superfície radicular. No terço apical havia indícios de neoformação óssea na intimidade do ligamento periodontal (Figura 27), que num período mais avançado poderá caracterizar o fenômeno da anquilose.

\section{Cortes transversais}

Terço cervical

Neoformação de tecido conjuntivo bem celularizado à guisa de ligamento periodontal, mas a inserção das fibras à superfície radicular não assumiu posicionamento radiado.

Terço médio

Tecido conjuntivo neoformado, bem vascularizado, posicionando-se como ligamento periodontal. Em alguns segmentos, a inserção à superfície radicular assumiu características de ligamento, porém em outros a disposição foi quase paralela. Lacunas de reabsorção dentinária inflamatória foram raras, de pequenas dimensões, tanto em profundidade quanto em extensão.

Terço apical

Neste segmento, como nos terços anteriores, havia presença de tecido conjuntivo neoformado funcionando como ligamento periodontal, mas de modo geral, a sua inserção na superfície radicular não teve características típicas de ligamento. Observaram-se também alguns pontos de neoformação óssea nesse tecido conjuntivo, aproximando-se da superfície radicular, o que, provavelmente, levará ao desenvolvimento do processo da anquilose. 


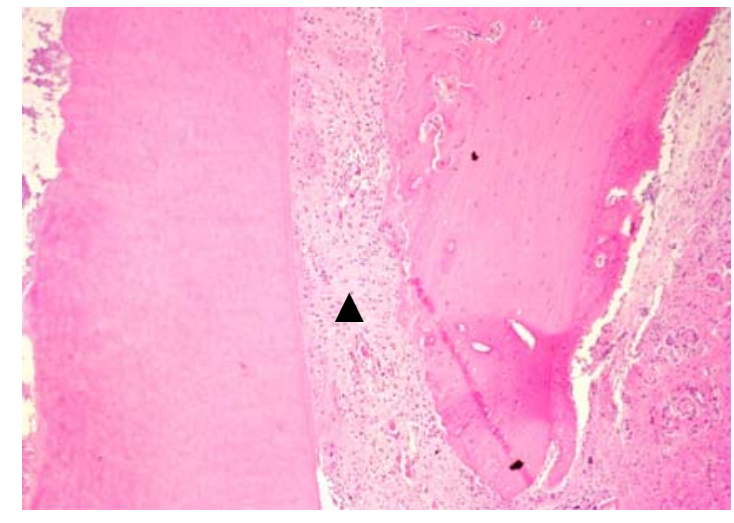

FIGURA 25 - Corte longitudinal. Grupo II, 15 dias. Reinserção perpendicular $(\boldsymbol{\Lambda})$ das fibras do ligamento periodontal, no terço cervical. Objetiva 10X

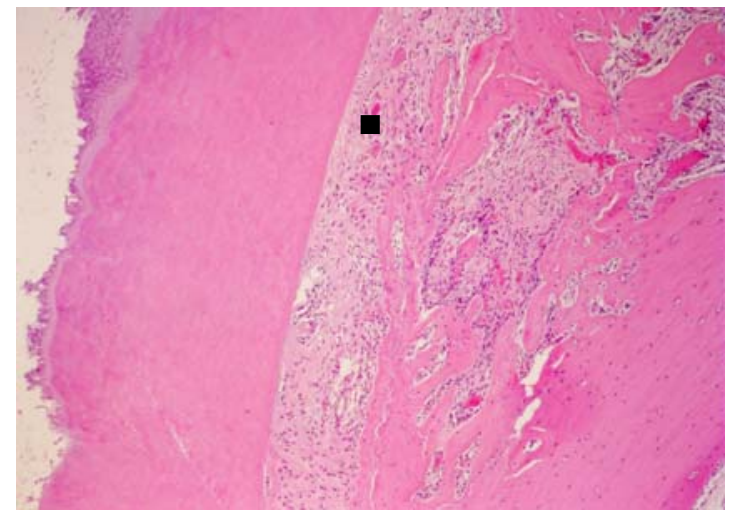

FIGURA 26 - Corte longitudinal. Grupo II, 15 dias. Reinserção do ligamento periodontal com fibras dispostas paralelamente (घ). Objetiva 10X

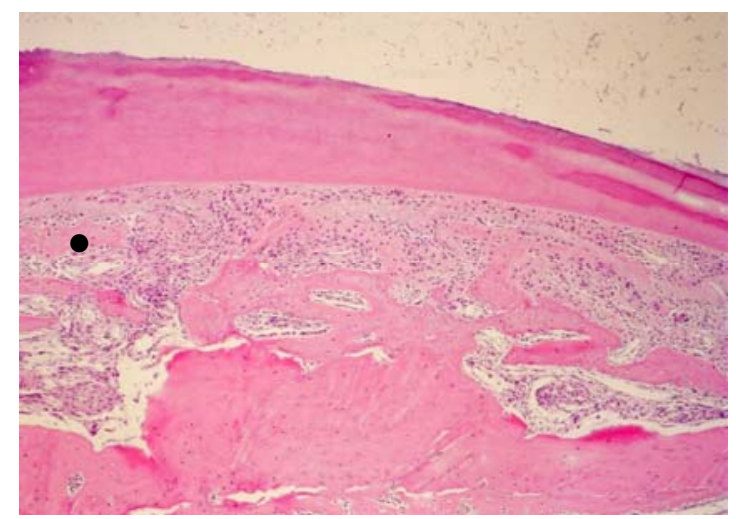

FIGURA 27 - Corte longitudinal. Grupo II, 15 dias. Neoformação óssea que avança em direção ao ligamento periodontal $(\bullet)$. Objetiva $10 \mathrm{X}$ 


\section{Período de 60 dias}

Cortes longitudinais

Ao longo dos terços cervical e médio da raiz, havia a predominância da anquilose alvéolo-dentária (Figura 28) intercalando-se com segmentos de tecido conjuntivo à guisa de ligamento periodontal, porém não mostrando reinserção perpendicular à superfície. Em alguns pontos ocorreram discretíssimas áreas de reabsorção, quase que somente restritas ao cemento (Figura 29).

No segmento apical, apesar da existência de um tecido conjuntivo com características semelhantes às do ligamento periodontal, este se apresentou estruturalmente desorganizado.

\section{Cortes transversais}

Terços cervical, médio e apical

Nesses cortes havia tecido conjuntivo substituindo o ligamento periodontal, porém a disposição das fibras era paralela à superfície radicular.

\section{Período de 90 dias}

Cortes longitudinais

Presença de anquilose nos segmentos cervical e médio, atingindo parte do apical (Figuras 30 e 31). As áreas de reabsorção inflamatória ou por substituição detectadas eram pequenas e rasas, atingindo porções restritas de cemento.

No terço apical praticamente não se observou presença de ligamento periodontal e este, quando presente, apresentou-se desorganizado. 
Cortes transversais

Terços cervical, médio e apical

Presença de anquilose intercalada com áreas de tecido conjuntivo bem celularizado, isento de células inflamatórias e aderido à superfície da raiz, não apresentando, porém, características de ligamento periodontal. 


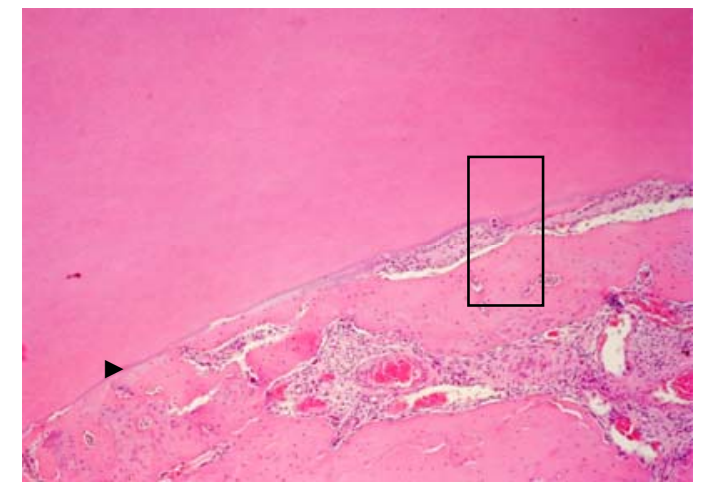

FIGURA 28 - Corte longitudinal. Grupo II, 60 dias. Áreas de anquilose ( $)$. Objetiva 10X

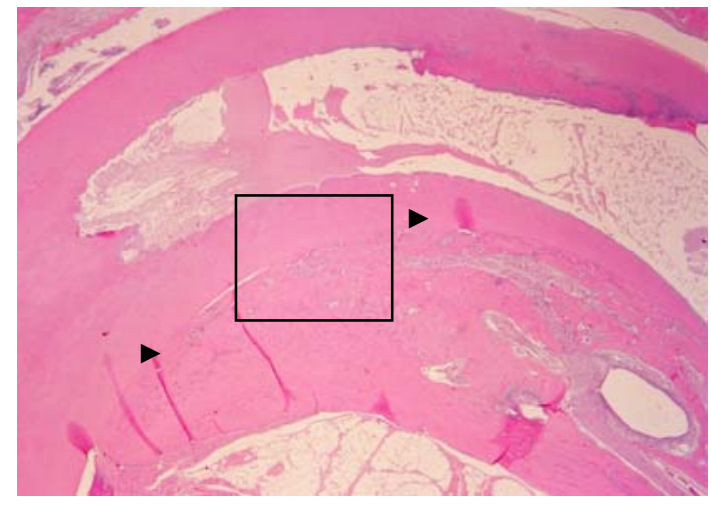

FIGURA 30 - Corte longitudinal. Grupo II, 90 dias. Predominância de áreas de anquilose $(\triangleright)$. Objetiva $2,5 \mathrm{X}$

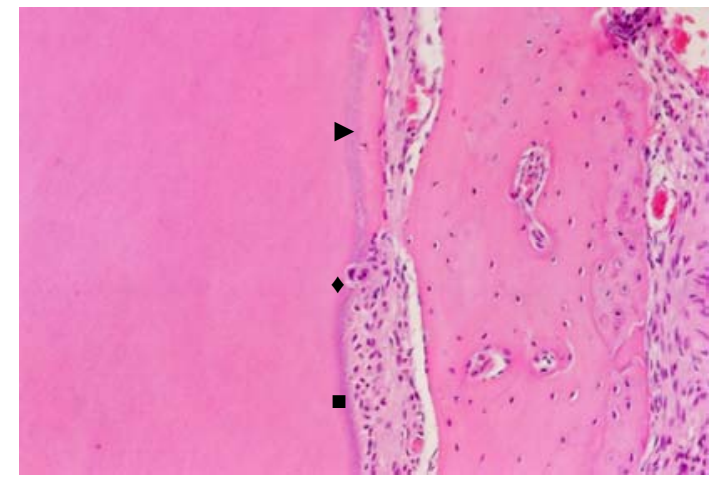

FIGURA 29 - Corte longitudinal. Grupo II, 60 dias. Reabsorção restrita ao cemento ( $\bullet$ ), tecido conjuntivo com fibras paralelas à superfície da raiz $(\boldsymbol{\square})$ e anquilose $(\boldsymbol{\nabla})$. Objetiva 25X

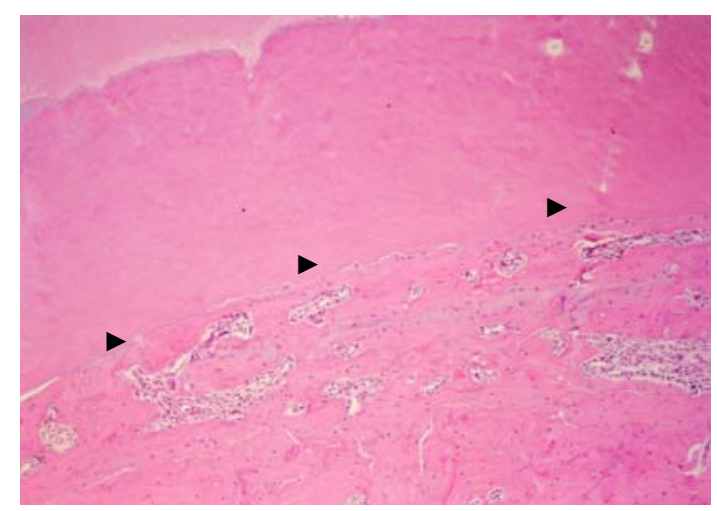

FIGURA 31 - Corte longitudinal. Grupo II, 90 dias. Extensas áreas de anquilose $(\triangleright)$. Objetiva 10X 
5.3 GRUPO III: Tempo de permanência extra-alveolar a seco de 60 minutos

\section{Período de 15 dias}

Cortes longitudinais

Ao longo da superfície radicular os espécimes exibiram áreas de espaço periodontal preenchidas por tecido conjuntivo neoformado, denso, rico em células fibroblásticas, tendo de permeio focos esparsos de infiltrado inflamatório crônico com algumas células gigantes multinucleadas. Esse tecido, de modo geral, estava aderido ao longo da raiz, porém as fibras não se apresentaram perpendiculares à superfície da raiz, exceto num pequeno segmento do terço cervical (Figuras 32 e 33).

\section{Cortes transversais}

Nos terços cervical, médio e apical observou-se no espaço periodontal neoformação de tecido conjuntivo, bem celularizado, com discreto infiltrado inflamatório crônico e aderido à superfície radicular, porém desorganizado. No terço apical, entretanto, observou-se um pequeno segmento de reinserção de tecido conjuntivo, assumindo posicionamento perpendicular à raiz.

\section{Período de 60 dias}

Cortes longitudinais

Presença de extensas áreas de anquilose, abrangendo terços cervical e médio (Figura 34). No espaço periodontal do terço apical, as áreas de anquilose eram menores e observou-se a presença de tecido conjuntivo neoformado, resquícios de pasta obturadora e algum foco de reação inflamatória (Figura 35). 
Cortes transversais

Nos terços cervical e médio a neoformação óssea aderida à superfície radicular, caracterizando a anquilose, foi predominante, entremeada por tecido conjuntivo bem celularizado e vascularizado, destituído de células inflamatórias. No terço apical a situação se repetiu com menor intensidade. Os pontos de anquilose eram menores e o tecido conjuntivo, à guiza de ligamento periodontal, apresentava-se desorganizado.

\section{Período de 90 dias}

Cortes longitudinais

Foram observadas extensas áreas de anquilose na superfície da raiz, abrangendo terços cervical e médio (Figura 36), com discretos focos de reação inflamatória e células gigantes (Figura 37).

No terço apical o espaço periodontal estava preenchido por tecido conjuntivo neoformado aderido à superfície radicular, mostrando uma pequena área de reinserção perpendicular numa faixa de cemento pré-existente, havendo mais abaixo, resquícios de pasta medicamentosa e infiltrado inflamatório.

\section{Cortes transversais}

Nos terços cervical e médio houve predominância do fenômeno da anquilose intercalado com áreas de tecido conjuntivo neoformado aderido à superfície radicular.

No terço apical a presença de anquilose foi discreta, havendo predomínio de tecido conjuntivo neoformado aderido à superfície radicular, além de remanescentes de pasta obturadora com focos de células inflamatórias. 


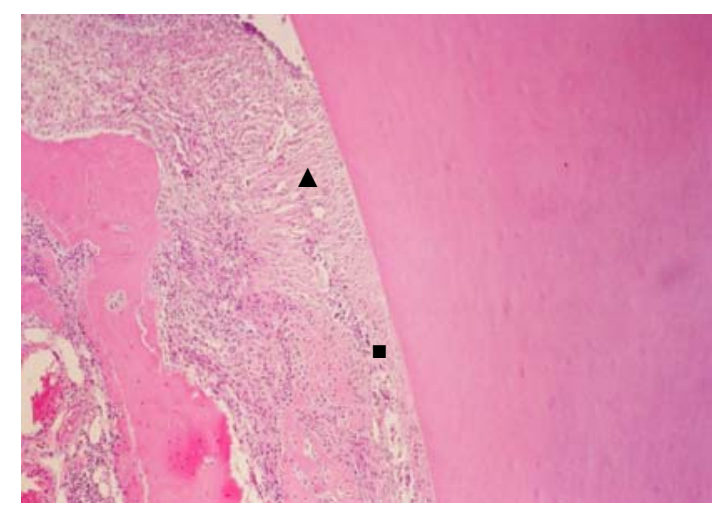

FIGURA 32 - Corte longitudinal. Grupo III, 15 dias. Pequeno segmento de reinserção paralela $(\boldsymbol{\square})$ e perpendicular $(\boldsymbol{\Delta})$ das fibras do ligamento periodontal, discreto infiltrado inflamatório. Objetiva 10X

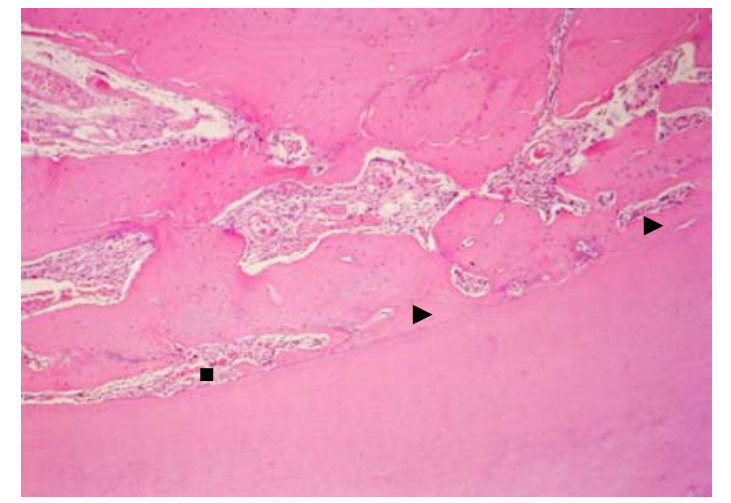

FIGURA 34 - Corte longitudinal. Grupo III, 60 dias. Áreas de anquilose (\) e segmentos de ligamento periodontal ( $(\mathbf{})$. Objetiva 10X.

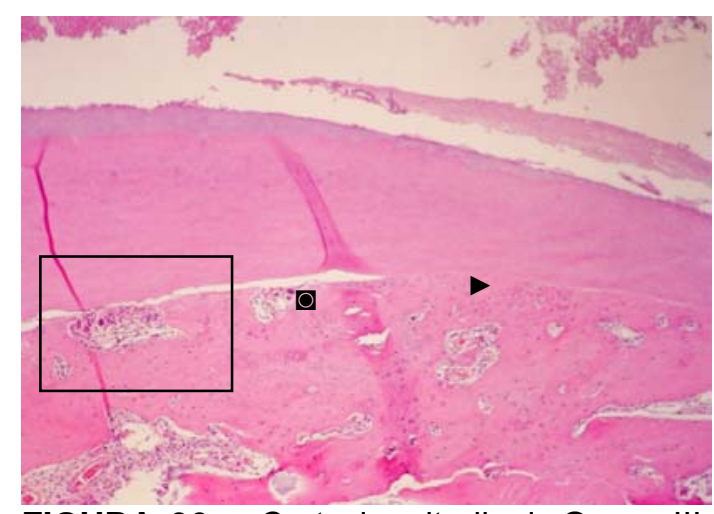

FIGURA 36 - Corte longitudinal. Grupo III, 90 dias. Anquilose ( $)$ e pequenas áreas de tecido conjuntivo com discreto infiltrado inflamatório crônico com algumas células gigantes (₫). Objetiva 10X.

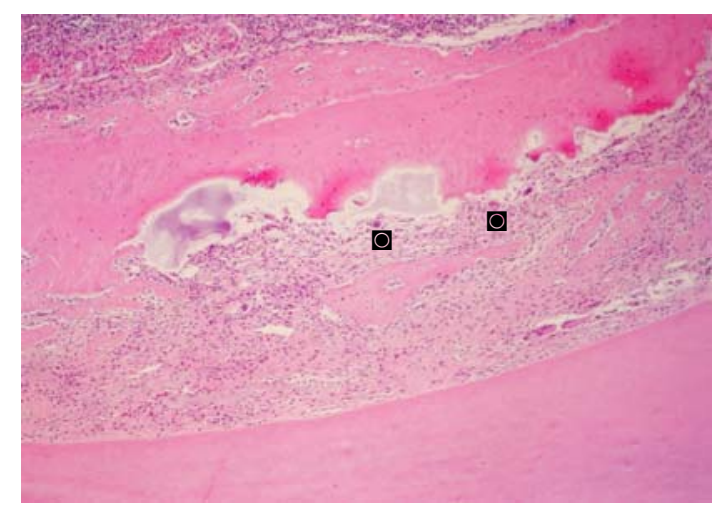

FIGURA 33 - Corte longitudinal. Grupo III, 15 dias. Ligamento periodontal com inserção desorganizada e células gigantes multinucleadas (匹). Objetiva 10X

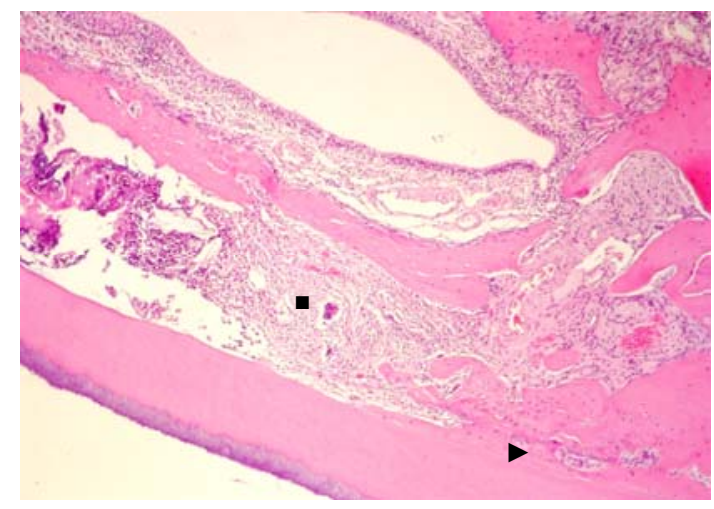

FIGURA 35 - Corte longitudinal. Grupo III, 60 dias. Tecido conjuntivo neoformado e desorganizado no terço apical ( $\mathbf{a})$, além de segmentos de anquilose ( $(\mathbf{)}$. Objetiva 10X.

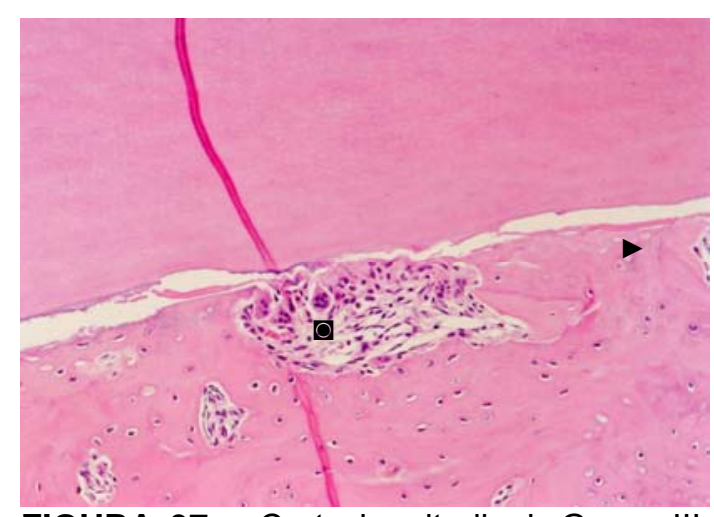

FIGURA 37 - Corte longitudinal. Grupo III, 90 dias. Anquilose $(\downarrow)$ e foco de reação inflamatória crônica discreta com algumas células gigantes multinucleadas (ם). Objetiva 25X. 


\section{Considerações gerais}

Para melhor compreensão e comparação dos resultados encontrados, elaboramos um quadro contendo os principais eventos microscópicos observados, bem como a freqüência com que eles ocorreram nos diferentes grupos e períodos experimentais (Figura 38). 
SINOPSE DA DESCRIÇÃO DOS RESULTADOS

\begin{tabular}{|c|c|c|c|c|c|c|c|c|c|}
\hline \multirow{4}{*}{$\begin{array}{l}\text { EVENTOS } \\
\text { MICROSCÓPICOS }\end{array}$} & \multicolumn{9}{|c|}{ TEMPo dE PERMANÊNCIA EXTRA-ALVEOLAR A SECO } \\
\hline & \multicolumn{3}{|c|}{15 MinUtos } & \multicolumn{3}{|c|}{30 MinUtOS } & \multicolumn{3}{|c|}{60 MinUtos } \\
\hline & \multicolumn{3}{|c|}{ GRUPO I } & \multicolumn{3}{|c|}{ GRUPO II } & \multicolumn{3}{|c|}{ GRUPO III } \\
\hline & 15 DIAS & 60 DIAS & 90 DIAS & 15 DIAS & 60 DIAS & 90 DIAS & 15 DIAS & 60 DIAS & 90 DIAS \\
\hline REABSORÇÃO INFLAMATÓRIA & + & +++ & +++ & + & + & + & & & \\
\hline REABSORÇÃO POR SUBSTITUIÇÃO & & +++ & +++ & & + & + & & & \\
\hline REABSORÇÃO COMUNICANTE & & +++ & +++ & & & & & & \\
\hline $\begin{array}{l}\text { ESPAÇO PERIODONTAL COM FIBRAS } \\
\text { PARALELAS À SUPERFÍCIE RADICULAR }\end{array}$ & +++ & + & + & +++ & ++ & + & +++ & + & + \\
\hline $\begin{array}{l}\text { ESPAÇO PERIODONTAL COM FIBRAS } \\
\text { PERPENDICULARES À SUPERFÍCIE RADICULAR }\end{array}$ & ++ & & & ++ & & & ++ & & + \\
\hline ANQUILOSE & + & +++ & +++ & + & ++ & +++ & & +++ & +++ \\
\hline
\end{tabular}

Figura 38 - Sinopse dos eventos microscópicos observados nos diferentes grupos e períodos experimentais

Legenda:

\begin{tabular}{|c|c|}
\hline & Ausente \\
\hline+ & Discreto \\
\hline++ & Moderado \\
\hline+++ & Intenso \\
\hline
\end{tabular}


6 Discussão 


\section{DISCUSSÃO}

\subsection{DA METODOLOGIA}

A utilização de ratos de laboratório (Rattus norvegicus albinus, Wistar) para se estudar a superfície radicular e as estruturas periodontais oferece algumas vantagens como a facilidade de obtenção dos animais, uma vez que é necessário curto tempo de procriação, as ninhadas dão muitos filhotes, e permite melhor controle genético, já que elimina fatores individuais como, por exemplo, deficiências imunes. Além disso, é possível a padronização do experimento, há facilidade de repetições e obtenção de amostras com grande número de animais. Devem ser ressaltados ainda fatores como o baixo custo de manutenção, a possibilidade de padronização da alimentação, a docilidade dos animais e, principalmente, o fato de que, apesar do seu tamanho reduzido, permite a obtenção de quantidades representativas de tecidos para inclusão e análise microscópica (SCHOUR; MASSLER $^{112}$, 1967). Deve ser acrescentado, ainda, que se trata de um animal que melhor representa o sistema mamífero (HEDRICH $\left.{ }^{58}, 2000\right)$.

Diante das inúmeras vantagens acima expostas, somando-se ainda o fato de que os resultados encontrados em vários trabalhos utilizando-se ratos, como modelo animal experimental para avaliar as alterações na superfície radicular e estrutura parendodôntica, são semelhantes ao de cães e macacos, justifica-se sua utilização inicial para se abrir caminhos para pesquisas em outros animais e até mesmo no homem (PANZARINI $^{98}, 2001$; SONODA et al. ${ }^{120}, 2000$, RENON ${ }^{105}, 1999$ ).

A extrapolação de resultados obtidos em animais, inclusive em ratos, para os humanos é possível e aceitável, com ressalvas, cautela e discernimento. Para tal, é imprescindível o conhecimento da fisiologia e anatomia dos animais em estudo, visando a correta interpretação dos 
resultados e a sua aplicação, como sugestiva, aos homens (SCHOUR; MASSLER $\left.^{112}, 1967\right)$.

$\mathrm{O}$ rato, por ter um metabolismo bastante acelerado, permite a obtenção de resultados num curto espaço de tempo. Existem relatos de que o período de vida de um mês em um rato equivale a trinta meses em humanos, se considerarmos que a expectativa de vida de um rato é de aproximadamente três anos, enquanto que no homem é de aproximadamente noventa anos (MORETTON $\left.{ }^{84}, 2000\right)$.

No presente estudo, utilizamos períodos experimentais de 15, 60 e 90 dias. Baseado no estudo de MORETTON ${ }^{84}$, em 2000, podemos sugerir que os resultados encontrados nesses períodos experimentais equivaleriam a 15, 60 e 90 meses em humanos, respectivamente.

A dentição do rato difere da dentição humana (SCHOUR; MASSLER $^{112}$, 1967) e alguns fatores foram considerados no momento de se estabelecer a metodologia desse trabalho, bem como para a obtenção dos resultados.

Embora os dentes dos mamíferos difiram morfologicamente entre si, eles são formados pelos mesmos componentes: esmalte, dentina, cemento e polpa. Os dentes podem ser simples ou complexos. Os dentes simples (braquiodontes) não continuam o crescimento após o término da erupção. Além disso, são divisíveis em coroa, colo e raiz definitivos. Já os dentes complexos (hipsodontes) são estruturas em constante erupção. Esses dentes não possuem coroa, colo e raiz definitivos. São dentes hipsodontes os dentes molares dos ruminantes, todos os dentes dos cavalos, os incisivos dos roedores e os caninos dos suínos (BANKS ${ }^{21}$, 1992).

Além do crescimento contínuo, o incisivo superior do rato, utilizado em nosso estudo, exibe outras peculiaridades importantes, que o diferem dos incisivos humanos e que devem ser ressaltadas. Ele se 
apresenta encurvado tendo a forma de uma espiral logarítmica lateralmente seccionada. Esse incisivo pode ser dividido em duas porções, a porção labial ou convexa, revestida totalmente por esmalte e a porção lingual ou côncava, bem como as proximais, revestidas por cemento e com ligamento periodontal perpendicularmente inserido (SCHOUR; MASSLER ${ }^{112}$, 1967). Durante a análise dos resultados, apenas essas três superfícies ou faces, lingual e proximais, foram analisadas para a descrição.

Por causa da acentuada curvatura dentária, o procedimento utilizado para simular a avulsão dentária deveria ser da forma mais atraumática possível. Para isso, foram utilizados fórceps e sindesmótomos especialmente adaptados para a sindesmotomia, luxação e extração de dentes de ratos, de forma a lesar o mínimo possível o cemento presente na porção mais cervical da raiz e, dessa forma, não interferir no reparo dessa região e, conseqüentemente, nos resultados da pesquisa (OKAMOTO; $\mathrm{RUSSO}^{95}$, 1973). Para contornar o problema do crescimento contínuo dos incisivos dos ratos, durante o experimento, a papila dentária localizada na região apical foi excisionada.

É importante ressaltar que como o diâmetro incisal desses dentes é reduzido, a abertura coronária estaria impossibilitada. Sabendo-se que o dente de crescimento contínuo apresenta o ápice aberto (SCHOUR; MASSLER $^{112}$, 1967), a remoção da papila dentária facilitou também a intervenção endodôntica, realizada de maneira retrógrada. Assim, a polpa dentária foi removida, o canal radicular irrigado e a medicação intracanal inserida previamente ao reimplante dentário (OKAMOTO et al. ${ }^{96}$, 1995; PANZARINI ${ }^{98}, 2001$ ).

Outra peculiaridade anatômica que facilitou a metodologia foi a curvatura do incisivo. Após o reimplante nenhuma contenção foi necessária, uma vez que a própria conformação anatômica do dente foi suficiente para mantê-lo em sua posição original (OKAMOTO; OKAMOTO $\left.{ }^{94}, 1995\right)$. 
Quando o reimplante é realizado em até quinze minutos extraalveolar a seco após a avulsão, é considerado imediato. Nesses casos, não se faz necessário qualquer tratamento da superfície radicular antes do reimplante, bastando apenas o reposicionamento do dente no seu alvéolo (ANDERSSON; BODIN ${ }^{3}$, 1990; BARRETT; KENNY23 ${ }^{23}$ 1997). No grupo I, onde o tempo de permanência extra-alveolar foi de quinze minutos, a papila dentária e a polpa foram excisionadas e o canal radicular preenchido com o CALEN, uma vez que essa manobra não poderia ser realizada após o reimplante, via abertura coronária, como já explicado. Passados os quinze minutos pré-estabelecidos, o dente foi reimplantado.

Um período superior a quinze minutos extra-alveolar a seco, ocasionará o ressecamento e, conseqüentemente, a necrose do ligamento periodontal e do tecido pulpar, o que torna o prognóstico do reimplante desfavorável. Para esses casos, em que o reimplante é realizado tardiamente, há a necessidade do tratamento da superfície radicular e, posteriormente, da intervenção endodôntica (LÖE; WAERHAUG ${ }^{81}$, 1961; OKAMOTO et al. ${ }^{96}$, 1995; PANZARINI ${ }^{98}, 2001$ ).

O tratamento da superfície radicular anteriormente ao reimplante visa a remoção do ligamento periodontal necrosado (KANNO ${ }^{67}$, 1996; LINDSKOG et al. ${ }^{79}, 1985$; MURAD ${ }^{87}, 1982 ;$ RENON $^{105}, 1999$ ), a hidratação de eventuais remanescentes de tecido conjuntivo viável aderido à superfície, preservando a estrutura radicular (BJORVATN; MASSLER ${ }^{25}$, 1971; SHULMAN; GEDALIA; FEINGOLD ${ }^{115}, 1973$; SONODA ${ }^{119}, 1997$; SONODA et al. $\left.{ }^{120}, 2000\right)$ através da inibição de células reabsortivas (BJORVATIN; $M_{A S S L E R}{ }^{25}$, 1971) e, ainda, a promoção do reparo através da neoformação cementária (FILIPPI; POHL; VON ARX ${ }^{45}, 2001$ ).

Desse modo, o tratamento da superfície radicular é fundamental para propiciar o restabelecimento da normalidade e funcionabilidade do dente avulsionado e reimplantado (OKAMOTO et al. ${ }^{96}, 1995$; PANZARINI ${ }^{98}$, 2001; MORI $\left.{ }^{85}, 2002\right)$. 
Para a remoção do ligamento periodontal, existem na literatura duas formas preconizadas. Uma delas, através da remoção mecânica e outra, através da remoção química (ANDREASEN ${ }^{10}$, 1981; KANNO ${ }^{67}$, 1996; LINDSKOG et al. ${ }^{78}$, 1982; MURAD ${ }^{87}$, 1982, NAKANE; KAMEYAMA ${ }^{89}$, 1987; PANZARINI $^{98}$, 2001; POI et al. ${ }^{103}$, 2001; POLSON; PROYE ${ }^{104}$, 1982; RENON $^{105}$, 1999). A remoção mecânica do ligamento periodontal era feita através de curetas, brocas ou lâminas de bisturi, porém esse método não apresentava os melhores resultados, pois além de remover o ligamento periodontal necrosado, eliminava também o cemento presente na superfície radicular, expondo dentina e dificultando consideravelmente o reparo (ANDREASEN $^{10}$, 1981; MURAD ${ }^{87}$, 1982, NAKANE; KAMEYAMA ${ }^{89}, 1987$; RENON $\left.^{105}, 1999\right)$.

$\mathrm{Na}$ tentativa de eliminar as dificuldades para o processo de reparo, o ligamento periodontal necrosado passou a ser removido com substâncias químicas e a escolhida foi o hipoclorito de sódio a $10 \%$ (LINDSKOG et al. ${ }^{79}$, 1985), que tem a propriedade de dissolver componentes orgânicos, como gorduras, além de desnaturar proteínas (GROSSMAN; MEIMAN ${ }^{52}, 1941$ ), preservando o cemento e a dentina.

A investigação sobre a eficácia do hipoclorito de sódio na remoção do ligamento periodontal de dentes avulsionados, previamente ao reimplante, teve continuidade. Diversos autores estudaram concentrações diferentes, tempo de permanência do dente na solução, além de seu volume. Quanto ao efeito de diferentes concentrações de hipoclorito de sódio sobre o reparo de dentes reimplantados, a grande maioria concluiu que o uso de baixas concentrações foi aceitável para a remoção do ligamento periodontal necrosado sem, contudo, dificultar o reparo (KANNO ${ }^{67}$, 1996; PANZARINI ${ }^{98}$, 2001; RENON ${ }^{105}$, 1999; SONODA ${ }^{119}$, 1997). A solução de hipoclorito de sódio na concentração de $1 \%$ foi suficiente para a remoção do tecido conjuntivo aderido à superfície radicular de forma eficaz e, além disso, preservou as estruturas de cemento e dentina e foi menos irritante, 
favorecendo melhor reparo do dente reimplantado, quando comparada às concentrações mais elevadas (KANNO $\left.{ }^{67}, 1996\right)$.

O tempo de permanência do dente avulsionado na solução de hipoclorito de sódio é muito variável. A literatura apresenta experimentos de 10 segundos até 12 dias de permanência na referida solução (HASSELGREN; OLSSON; CVEK ${ }^{57}$, 1988; LINDSKOG et al. ${ }^{79}$, 1985; NAKAMURA et al. ${ }^{88}$, 1985; PANZARINI ${ }^{98}, 2001$; SONODA $^{119}$, 1997) e o tempo de 30 minutos pareceu ser suficiente para a remoção do ligamento periodontal necrosado sem, contudo, promover danos ao cemento e dentina, dificultando o reparo (PANZARINI $\left.{ }^{98}, 2001\right)$.

O volume da solução de hipoclorito de sódio a ser empregado também foi objeto de estudo de alguns autores. POI et al. ${ }^{103}$, em 2001, experimentaram diferentes volumes $(5,10,50$ e $100 \mathrm{ml})$ de hipoclorito de sódio a $1 \%$ para a remoção do tecido conjuntivo necrosado aderido à superfície da raiz e concluíram que o volume da solução era diretamente proporcional à sua capacidade de remoção da matéria orgânica. Porém, os volumes de 50 e $100 \mathrm{ml}$ se comportaram de forma semelhante, não havendo diferença significativa entre eles.

Em nosso trabalho, em concordância com a literatura estudada, os dentes dos grupos II e III, após o período extra-alveolar a seco de 30 e 60 minutos, respectivamente, foram imersos em $50 \mathrm{ml}$ de solução de hipoclorito de sódio a $1 \%$ por um período de 30 minutos para a remoção do ligamento periodontal necrosado antes do reimplante.

Nos dentes com rizogênese completa, em que o reimplante dentário é realizado de forma tardia, ou seja, períodos extra-alveolares superiores a 60 minutos, faz-se necessária a remoção da polpa e a instrumentação do canal radicular previamente à reimplantação daquele no alvéolo, uma vez que o tecido pulpar já se encontra necrosado (TROPE ${ }^{124}$, 2002). 
A medicação intracanal ideal é a pasta à base de hidróxido de cálcio que deve ser colocada após o reimplante, o mais rapidamente possível (TROPE $\left.{ }^{124}, 2002\right)$. Além de ter ação antibacteriana (ESTRELA; PESCE ${ }^{44}$, 1996; SJOGREN et al. ${ }^{118}$, 1991; SAFAVI; NICHOLS ${ }^{109}, 1993$; SIQUEIRA JR; LOPES $\left.{ }^{117}, 1999\right)$, inibe ou elimina a reabsorção inflamatória (TRONSTAD ${ }^{122}$, 1988; TROPE et al. $\left.{ }^{126}, 1995\right)$ e ainda cria condições favoráveis para a ocorrência do reparo (TRONSTAD et al. ${ }^{123}, 1981$ ). A pasta de hidróxido de cálcio foi utilizada como medicação intracanal em todos os grupos, previamente ao reimplante, uma vez que a medicação, como já dito, só poderia ser introduzida no canal radicular de maneira retrógrada.

A pasta de hidróxido de cálcio utilizada em nosso experimento foi a pasta $\mathrm{CALEN}^{\circledR}$, cuja proporção pó/líquido se apresenta constante, sendo de fácil aplicação e tem como veículo o polietilenoglicol 400, um veículo viscoso, hidrossolúvel. Esta pasta possui excelentes propriedades físicoquímicas (LEONARDO; ARAÚJO; MENDES ${ }^{72}, 1976$ ), aliadas às propriedades biológicas ideais, como prolongada ação indutora de mineralização na área desejada (BENATTI NETO ${ }^{24}$, 1984) e biocompatibilidade (LEONARDO et al. ${ }^{73}$, 1993; LEONARDO et al. ${ }^{74}, 1996$ ).

Nos dentes com períodos extra-alveolares prolongados, além da remoção do ligamento periodontal necrosado, tem sido sugerido o tratamento da superfície radicular com várias substâncias na tentativa de inibir uma das mais indesejáveis conseqüências do reimplante dentário, a reabsorção radicular e, dessa forma, melhorar o prognóstico para o dente avulsionado e reimplantado (SELVIG et al. ${ }^{114}$, 1992). Em 1994, a AMERICAN ASSOCIATION OF ENDODONTICS ${ }^{2}$ recomendou o uso do fluoreto de sódio como tratamento de superfície radicular de dentes avulsionados antes do reimplante.

Apesar dos efeitos benéficos do fluoreto de sódio na tentativa de atenuar o processo reabsortivo da raiz, as pesquisas mostraram que essa substância apenas retarda esse processo sem, contudo, evitá-lo ou paralisálo totalmente (BJORVATN; MASSLER ${ }^{26}$, 1971, SHULMAN; GEDALIA; 
FEINGOLD ${ }^{115}$, 1973). Dessa forma, é incessante a busca de uma substância capaz de prevenir e reparar áreas de reabsorção radicular em dentes avulsionados e reimplantados tardiamente. Algumas delas, como a acetazolamida, não foram capazes de evitar a reabsorção radicular ou reparar áreas reabsorvidas $\left(\mathrm{MORI}^{85}, 2002\right)$. Outras vêm sendo estudadas e têm demonstrado resultados iniciais satisfatórios, como 0 alendronato (LEVIN et al. ${ }^{75}$, 2001) e a proteína derivada da matriz do esmalte (EMDOGAIN®) (FILIPPI, POHL, VON ARX ${ }^{45}$; IQBAL; BAMAAS ${ }^{63}, 2001$, 2001). Esta, além de tornar a raiz mais resistente à reabsorção, estimula a formação de novo ligamento periodontal de origem alveolar. TROPE ${ }^{124}$, 2002, ressaltou a importância de mais pesquisas sobre essas substâncias para recomendarmos seu emprego.

Como visto na literatura, o alendronato é um composto aminobifosfonato, uma potente droga utilizada no tratamento da osteoporose, doença de Paget e outras desordens de reabsorção óssea (FLEISCH $^{47}$, 1989; FLEISCH ${ }^{48}$, 1991; FLEISCH ${ }^{49}$, 1993; KELLER; FLIESLER ${ }^{68}$, 1999; LIN $^{77}$, 1996). Os bifosfonatos têm efeito inibitório da reabsorção óssea pela inibição da atividade dos osteoclastos (MASARACHIA et al. $\left.^{82}, 1996\right)$ e o alendronato, particularmente, age induzindo apoptose dessas células (HUGHES et al. ${ }^{61}$, 1995).

O mecanismo de inibição das reabsorções tem sido atribuído ao decréscimo da atividade osteoclástica por recrutamento diminuído de clastos (BREUIL et al. ${ }^{29}$, 1998), à interferência sobre os receptores específicos dos osteoclastos para proteínas da matriz óssea (COLUCCl et al. ${ }^{34}$, 1998), à produção de um inibidor osteoclástico por osteoblastos, que reduzem o tempo de vida e/ou o número de osteoclastos diferenciados (VITTE et al. ${ }^{128}$,1996) e à paralização da reabsorção pela interferência com o bordo pregueado dos osteoclastos (SATO et al. ${ }^{111}, 1991$ ).

Nos grupos II e III, após a remoção do ligamento periodontal necrosado, as superfícies radiculares dos dentes foram tratadas com $50 \mathrm{ml}$ de solução alendronato de sódio a 3,2mg/l por 10 minutos. 
Existem poucos trabalhos na literatura utilizando o alendronato de sódio para tratamento da superfície radicular, ou seja, como medicação tópica. LEVIN et al. ${ }^{75}$, 2001, utilizaram o alendronato associado à solução de Hank, o que deixa dúvidas em relação aos resultados, uma vez que a solução de Hank poderia interferir diretamente nos resultados encontrados.

Dessa forma, para estabelecermos a concentração ideal da solução de alendronato de sódio para a realização do nosso trabalho, baseamo-nos na pesquisa de KUM et al. ${ }^{70}$, 2003, onde testaram o alendronato em diferentes concentrações: $10^{-7} \mathrm{M}, 10^{-6} \mathrm{M}$ e $10^{-5} \mathrm{M}$ como agentes intracanais para tratamento de reabsorções radiculares do tipo inflamatórias. A concentração de $10^{-5} \mathrm{M}$ foi a que mais significativamente inibiu a formação de osteoclastos.

A concentração que mais se aproximou da solução de $10^{-5} \mathrm{M}$ de alendronato de sódio e que foi possível ser manipulada em farmácias convencionais foi a de 3,2 mg de alendronato de sódio em água destilada qsp 1 litro. O tempo de imersão dos dentes nessa solução foi de 10 minutos, por não haver trabalho semelhante na literatura que pudesse servir como parâmetro. Como o tempo extra-alveolar do dente avulsionado deve ser o menor possível, estabelecemos o tempo de 10 minutos no alendronato como aceitável.

Após o tratamento de superfície com o alendronato de sódio por 10 minutos, o dente foi removido dessa solução e seu canal radicular preenchido com pasta à base de hidróxido de cálcio. Em seguida, o dente foi reimplantado cuidadosamente a fim de não causar dano adicional à superfície radicular e, como já dito, nenhuma contenção foi realizada.

A contenção em incisivos de ratos em experimentos simulando avulsão e reimplante dentário foi testada por OKAMOTO; OKAMOTO ${ }^{94}$, em 1995, verificando que a contenção provocava o deslocamento do dente contra a parede mesial do alvéolo e maior quantidade de reabsorção e anquilose eram observadas nessa área. Sendo assim, levando-se em 
consideração as desvantagens apresentadas e, pela facilidade do dente permanecer no seu alvéolo por causa da anatomia encurvada, nenhuma contenção fez-se necessária.

Para todos os espécimes foi instituída a antibioticoterapia após a cirurgia. O objetivo de tal procedimento foi prevenir a instalação de um processo infeccioso (PETTIETTE et al. ${ }^{101}$, 1997; SAE-LIM et al. ${ }^{108}, 1998$ ), uma vez que se tratou de um procedimento invasivo. O antibiótico de escolha foi a penicilina $\mathrm{G}$ benzatina, na dosagem única de 20.000 U.I. por via intramuscular. Trata-se de um antibiótico de largo espectro, perfeitamente indicado para tal procedimento, além de ser de fácil aplicação (ANDREASEN $\left.{ }^{19}, 1995\right)$.

Os espécimes foram analisados através de cortes longitudinais e transversais possibilitando, assim, englobar todos os eventos ocorridos nos diferentes grupos. A coloração com hematoxilina e eosina evidenciou os aspectos especificados para a análise das lâminas.

\subsection{DOS RESULTADOS}

Com a realização do reimplante imediato espera-se que ocorra a reinserção das fibras do ligamento periodontal presentes no alvéolo e na raiz do dente avulsionado, para que este possa novamente desempenhar suas funções normais (ANDREASEN ${ }^{12}$, 1985; ANDREASEN; ANDREASEN ${ }^{13}$, 1992; ANDREASEN; ANDREASEN ${ }^{14}$, 1994). Para que isso ocorra é fundamental que o reimplante seja realizado no menor tempo possível, no máximo quinze minutos (ANDERSSON; BODIN ${ }^{3}$, 1990; BARRETT; KENNY ${ }^{23}, 1997 ;$ TROPE $\left.^{124}, 2002\right)$.

Em nosso trabalho, nos espécimes do grupo I, aos 15 dias, apesar do reimplante ter sido realizado aos 15 minutos, observamos que não houve restabelecimento do ligamento periodontal, mas neoformação de 
tecido conjuntivo ocupando o espaço periodontal, cujas fibras dispunham-se, na sua maior parte, paralelamente à superfície radicular que, de modo geral, estava preservada. A presença de reabsorção e anquilose foi discreta.

Nos períodos mais longos, de 60 e 90 dias, os eventos microscópicos apresentaram-se mais drásticos. A reabsorção inflamatória era intensa, exibindo áreas de comunicação com o canal radicular, bem como os fenômenos de anquilose e reabsorção por substituição. A incidência agressiva dos fenômenos reabsortivos nos espécimes reimplantados aos quinze minutos da avulsão (grupo I) demonstrou o insucesso do procedimento, contrariando as vantagens do reimplante imediato realizado em macacos (HAMMARSTRÖM; BLOMLÖF; LINDSKOG $^{53}$, 1989) e em humanos (ANDERSSON; BODIN ${ }^{3}$, 1990; BARRETT; KENNY ${ }^{23}$, 1997; TROPE ${ }^{124}, 2002$ ).

Em um estudo avaliando 400 dentes humanos avulsionados e reimplantados, ANDREASEN et al. $^{20}$ (1995) encontraram reparo do ligamento periodontal em $73 \%$ dos dentes reimplantados em até 5 minutos, ao passo que, onde houve o armazenamento dos dentes em diferentes meios de conservação previamente ao reimplante, o reparo do ligamento periodontal ocorreu em apenas $18 \%$ deles.

Esse desencontro de resultados deve ser interpretado com restrições, considerando o modelo experimental utilizado para este experimento, o rato de laboratório. Esse animal tem o seu metabolismo mais acelerado do que de outros animais e o do homem (MORETTON et al. ${ }^{84}$, 2000). Provavelmente, em razão disso, o período máximo de até 15 minutos de permanência extra-alveolar a seco, preconizado como aceitável para o sucesso do reimplante dentário em humanos, tenha sido excessivo para os ratos, descaracterizando o reimplante imediato. Sendo assim, há necessidade de procurar para o rato de laboratório o período máximo de permanência extra-alveolar a seco do dente avulsionado, correspondente ao de 15 minutos, tido como aceitável para o homem. 
$\mathrm{Na}$ tentativa de minimizar ou bloquear o processo da reabsorção inflamatória, bem como os possíveis efeitos da contaminação bacteriana, foi colocada pasta de hidróxido de cálcio (ESTRELA; PESCE ${ }^{44}$, 1996; SJOGREN et al. ${ }^{118}$, 1991; SAFAVI; NICHOLS ${ }^{109}$, 1993; TRONSTAD ${ }^{122}$, 1988; TROPE et al. ${ }^{126}, 1995$; TROPE $^{124}, 2002$ ) no interior do canal radicular em todos os grupos experimentais. No grupo I, cujo reimplante foi realizado em quinze minutos, esse medicamento não impediu o aparecimento da reabsorção inflamatória que, nos períodos experimentais de 60 e 90 dias, chegou a provocar a comunicação do periodonto com o canal radicular. Foi notória, também nesse grupo, a tentativa do organismo de reinserir as fibras do ligamento periodontal, porém isso não ocorreu de forma perpendicular, mas sim paralelamente à superfície radicular.

Essa reinserção paralela das fibras periodontais também ocorreu em outros trabalhos (EHNVID et al. ${ }^{42}, 1993$; KANNO ${ }^{67}, 1996$; SONODA ${ }^{119}$, 1997, SONODA et al. ${ }^{120}$, 2000). Quando o ligamento periodontal é mantido na superfície cementária, cria-se uma situação propícia para a proliferação de células mesenquimais indiferenciadas oriundas do osso alveolar. Em contrapartida, a remoção desse ligamento (grupos II e III) levaria à exposição de uma superfície mineralizada que não permitiria a aderência daquelas células mesenquimais, importantíssimas para a regeneração do ligamento periodontal. Dessa forma, o tecido conjuntivo periodontal que permaneceu aderido à parede do alvéolo, após o reimplante, teria a tendência de formar uma cápsula envolvendo a raiz do dente reimplantado, impossibilitando completamente a reinserção de fibras colágenas na superfície do cemento. Em nosso trabalho, a situação foi semelhante, pois, com a remoção química do ligamento periodontal aderido ao cemento (grupos II e III), o tecido conjuntivo denso neoformado envolveu a superfície radicular em todos os grupos experimentais. Nos períodos mais tardios $(60 \mathrm{e}$ 90 dias), ele foi gradativamente sendo substituído por tecido ósseo, caracterizando o fenômeno da anquilose. Este evento está de acordo com a proposta de EHNVID et al. ${ }^{42}$ (1993), de que o tecido conjuntivo neoformado, 
após o reimplante do dente avulsionado, à guisa de ligamento periodontal, propiciaria a ocorrência da anquilose.

O desenvolvimento da reabsorção inflamatória está relacionado, principalmente, a períodos extra-alveolares extensos em meio seco (TRONSTAD $^{122}$, 1988; TROPE $^{124}, 2002$; FINUCANE, KINIRONS ${ }^{46}$, 2003) e à presença de contaminação (ANDREASEN ${ }^{11}$, 1981; ANDREASEN, HJORTING-HANSEN ${ }^{16}$, 1966; HAMMARSTRÖM et al. ${ }^{56}$, 1986; NISHIOKA, et al. 92, 1998; TROPE ${ }^{124}$, 2002; FINUCANE, KINIRONS ${ }^{46}$, 2003). No rato, como já comentado, o período de 15 minutos extra-alveolar pode ser excessivo. Desse modo, os eventos reabsortivos foram intensos nos períodos de 60 e 90 dias havendo, concomitantemente à reabsorção inflamatória, a ocorrência de anquilose e reabsorção por substituição.

A anquilose e, conseqüentemente, a reabsorção por substituição estão relacionadas a danos iniciais à superfície radicular provocados por períodos extra-alveolares extensos, ressecando a superfície da raiz e comprometendo a camada de cemento (ANDREASEN ${ }^{8}$, 1980; TRONSTAD ${ }^{122}$, 1988; FINUCANE; KINIRONS ${ }^{46}$, 2003). TRONSTAD ${ }^{122}$, 1988, afirmou que a quantidade de cemento danificado por unidade de área da superfície radicular estaria relacionada à ocorrência da anquilose e, por conseguinte, da reabsorção por substituição. Outros autores, como LÖE; WAERHAUG ${ }^{81}$, 1961, afirmaram que a ausência de restos epiteliais de Malassez no ligamento periodontal ressecado levaria ao desenvolvimento da anquilose, pois aqueles seriam responsáveis pela manutenção do espaço periodontal.

Num trauma como a avulsão, por exemplo, ocorre a morte os cementoblastos e a eliminação dos restos epiteliais de Malassez presentes no ligamento periodontal, o que favorece o aparecimento da reabsorção por substituição (HAMMARSTRÖM, BLOMLÖF, LINDSKOG ${ }^{53}$, 1989). Após o reimplante, os cementoblastos são substituídos por osteoblastos, que apresentam receptores para o paratormônio. Este fato, aliado ao contato osso/ dentina/ cemento, permite que o dente participe da renovação óssea 
sendo, assim, gradativamente substituído por osso, propiciando a exposição de antígenos seqüestrados e desencadeando a resposta imunopatológica (CONSOLARO ${ }^{35}$, 2002; HIDALGO ${ }^{59}$, 2001).

Quando o reimplante imediato não for possível, situação que ocorre na maioria dos casos de avulsão que chegam aos consultórios odontológicos (SONODA ${ }^{119}$, 1997; SONODA et al. ${ }^{120}, 2000$ ), o reimplante tardio deve ser realizado, aplicando o tratamento da superfície radicular e empregando substâncias que visem evitar ou, ao menos, retardar o aparecimento das reabsorções (BJORVATN; MASSLER ${ }^{25}$, 1971; SHULMAN; GEDALIA; FEINGOLD ${ }^{115}$, 1973; SONODA $\left.{ }^{119}, 1997\right)$.

Apesar do grande número de substâncias testadas para o tratamento da superfície radicular, nenhuma delas conseguiu, ainda, evitar totalmente o desenvolvimento de tais lesões $\left(\mathrm{MORI}^{85}, 2002\right.$; ESCOBAR ${ }^{43}$, 1997; PERCINOTO ${ }^{100}$, 1986; SELVIG et al. ${ }^{114}$, 1992). Os resultados mais favoráveis foram obtidos com o uso de fluoretos (BJORVATN; MASSLER ${ }^{25}$, 1971; COCCIA ${ }^{33}$, 1980; SHULMAN; GEDALIA; FEINGOLD ${ }^{115}$, 1973; WIKESJÖ et al. ${ }^{129}$, 1991), tanto em cães, quanto em macacos e ratos. Os fluoretos levaram à formação de cristais de fluorapatita sobre a superfície radicular inibindo a ação das células clásticas e diminuindo a incidência de reabsorção.

Estudos em ratos e cães mostraram que a utilização do flúor precedida do uso do hipoclorito de sódio leva a um prognóstico mais favorável do que quando se utiliza apenas o flúor (PANZARINI ${ }^{98}, 2001$; SONODA $^{119}$, 1997). $\mathrm{O}$ alto $\mathrm{pH}$ do hipoclorito de sódio parece ser $\mathrm{O}$ responsável pela menor incidência de reabsorção (ESCOBAR ${ }^{43}, 1997$; PERCINOTO $\left.{ }^{100}, 1996\right)$.

Em outros trabalhos, em períodos experimentais mais longos, apesar do uso do fluoreto de sódio precedido da utilização do hipoclorito de sódio, alguns espécimes mostraram anquilose e reabsorção por substituição e inflamatória extensas $\left(\mathrm{MORI}^{85}, 2002\right.$; SHULMAN; GEDALIA; 
FEINGOLD ${ }^{115}$, 1973), contradizendo os achados de PANZARINI ${ }^{98}, 2001 \mathrm{e}$ SONODA $^{119}, 1997$.

À semelhança do flúor, o alendronato, substância largamente utilizada no tratamento da osteoporose (KELLER; FLIESLER ${ }^{68}$, 1999), por inibir a atividade dos osteoclastos durante a reabsorção óssea (MASARACHIA et al. ${ }^{82}$, 1996), liga-se aos cristais de hidroxiapatita do osso, preferencialmente às superfícies que estão sofrendo atividade de reabsorção osteoclástica (SELBY $\left.{ }^{113}, 1996\right)$.

Nos grupos II e III, 30 e 60 minutos extra-alveolar respectivamente, ligamento periodontal removido com hipoclorito de sódio a $1 \%$ e tratamento da superfície radicular com o alendronato, os resultados encontrados foram semelhantes, denotando que a variação do período de tempo extra-alveolar não mostrou diferenças significativas. O tecido periodontal neoformado, inserido paralelamente à superfície radicular e observado com maior freqüência nos períodos de 15 dias, foi sendo substituído por tecido ósseo até se justapor à superfície da raiz, caracterizando a anquilose. Porém, tanto no grupo II como no III, não se observaram áreas de reabsorção radicular consideráveis. Pequenas extensões de reabsorção, descritas como discretas, envolvendo cemento ou profundidades mínimas de dentina foram observadas no grupo II.

A remoção do ligamento periodontal com hipoclorito de sódio em dentes avulsionados deixa uma superfície radicular exposta rica em hidroxiapatita, que seria facilmente reconhecida por clastos, levando ao desenvolvimento da reabsorção radicular (EHNEVID et al. $^{42}$, 1993). O alendronato, por sua vez, tem a propriedade de se ligar aos cristais de hidroxiapatita do osso (SELBY $\left.{ }^{113}, 1996\right)$. Da mesma forma, ele se ligaria aos cristais de hidroxiapatita da superfície radicular expostos pelo hipoclorito de sódio, impedindo a ação dos osteoclastos e, conseqüentemente, a ocorrência de reabsorção (MASARACHIA et al. ${ }^{82}$, 1996). 
A afinidade do alendronato por fosfato de cálcio e sua forte ligação à hidroxiapatita, propicia sua rápida incorporação ao esqueleto $\left(\right.$ FLEISCH ${ }^{49}$, 1993). Pesquisas mostraram que, uma vez incorporado ao osso, o alendronato fica retido por prolongados períodos e o tempo de vida estimado para eliminá-lo do esqueleto pode chegar a 10 anos (KANIS et al. $66,1995)$.

O alendronato não tem a propriedade de impedir a anquilose, observada principalmente nos períodos experimentais de 60 e 90 dias dos grupos II e III, porém não se observou a ocorrência de reabsorções extensas, principalmente no grupo III. O alendronato, utilizado no tratamento da superfície radicular, provavelmente se incorporou aos cristais de hidroxiapatita expostos na raiz pela ação do hipoclorito de sódio a $1 \%$, inibindo a atividade osteoclástica e, assim, a reabsorção, conforme a proposta de SELBY ${ }^{113}, 1996$.

De acordo com os resultados encontrados e comparando-os com a literatura consultada, os achados são bastante animadores em relação ao tratamento tópico da superfície radicular com o alendronato de sódio. Porém, outras pesquisas são necessárias, principalmente utilizando-se períodos experimentais mais prolongados e comparando os resultados encontrados com grupos que utilizem o fluoreto de sódio a $2 \%$, até então a substância preconizada como ideal para o tratamento da superfície radicular após reimplantes tardios $\left(\right.$ TROPE $^{124}, 2002$; AMERICAN ASSOCIATION OF ENDODONTICS $\left.{ }^{2}, 1994\right)$. 
7 Conclusões 


\section{CONCLUSÕES}

De acordo com a metodologia utilizada e os resultados encontrados, pode-se concluir que:

- O tratamento tópico da superfície radicular com a solução de alendronato de sódio não evitou a ocorrência da anquilose dento-alveolar, mas foi capaz de diminuir a incidência de reabsorção radicular.

- A variação do tempo extra-alveolar entre os grupos II e III não interferiu de maneira significativa nos resultados obtidos. 


\section{REFERÊNCIAS Bibliográficas}




\section{REFERÊNCIAS BIBLIOGRÁFICAS}

1 ALEXANDER, P. C. Replantation of teeth. Oral Surg, v.19, n.1, p.1109, 1956.

2 AMERICAN ASSOCIATION OF ENDODONTISTS. Treatment of avulsed permanent tooth. Recommended guidelines of the A.A.E. Dent Clin North Amer, v.39, n.1, p.221-5, 1995.

3 ANDERSSON, L.; BODIN, I. Avulsed human teeth replanted within 15 minutes: a long-term clinical follow-up study. Endod Dent Traumat, v.6, n.1, p.37-42, 1990.

4 ANDERSSON, L. et al. Tooth ankylosis. Int J Oral Surg, v.13, p.42331, 1984.

5 ANDREASEN, J. O. Etiology and pathogenesis of traumatic dental injuries. A clinical study of 1.298 cases. Scand J Dent Res, v.78, n.4, p.329-42, 1970.

ANDREASEN, J. O. Analysis of pathogenesis and topography of replacement root resorption (ankylosis) after replantation of mature permanent incisors in monkeys. Sweed Dent J, v.4, p.231-40, 1980.

7 ANDREASEN, J. O. Analysis of topography of surface and inflammatory root resorption after replantation of mature permanent incisors in monkeys. Sweed Dent J, v.4, p.135-44, 1980.

8 ANDREASEN, J. O. A time related study of periodontal healing and root resorption activity after replantation of mature permanent incisors in monkeys. Sweed Dent J, v.4, p.101-11, 1980.

9 ANDREASEN, J. O. Effect of extra-alveolar period and estorage media upon periodontal and pulpal healing after replantation of mature incisors in monkeys. Int J Oral Surg, v.10, p.43-53, 1981.

10 ANDREASEN, J. O. Interrelation between alveolar bone and periodontal ligament repair after replantation of mature permanent incisors in monkeys. J Period Res, v.16, n.2, p.228-35, 1981.

11 ANDREASEN, J. O. Relatioship between superface and inflammatory resorption and changes in the pulp after replantation of permanent incisors in monkeys. J Endod, v.7, n.7, p.294-301, 1981.

\footnotetext{
Normas recomendadas para uso no âmbito da Universidade de São Paulo, com base no documento "Referências Bibliográficas: exemplos", emanados do Conselho Supervisor do Sistema Integrado de Bibliotecas da USP, em reunião de 20 de setembro de 1990.
} 
12 ANDREASEN, J. O. External root resorption: its implication in dental traumatology, paedodontics, periodontics, orthodontics and endodontics. Int Endod J, v.18, p.109-18, 1985.

13 ANDREASEN, J. O.; ANDREASEN, F. M. Root resorption following traumatic dental injuries. Proc Finn Dent Soc, v.88, p.95-114, 1992. Supplement 1.

14 ANDREASEN, J. O.; ANDREASEN, F. M. Textbook and color atlas of traumatic injuries to the teeth. St. Louis, Mosby, 1994.

15 ANDREASEN, J. O.; HJORTING-HANSEN, E. Replantation of the teeth I. Radiographic and clinical study of 110 human teeth replanted after accidental loss. Acta Odontol Scand, v.24, p.263-86, 1966.

16 ANDREASEN, J. O.; HJORTING-HANSEN, E. Replantation of the teeth II. Histological study of 22 replanted anterior teeth in humans. Acta Odontol Scand, v.24, p.287-306, 1966.

17 ANDREASEN, J. O.; KRISTERSON, L. The effect of limited drying or removal of the periodontal ligament. Periodontal healing after replantation of mature permanent incisors in monkeys. Acta Odont Scand, v.39, n.1, p.1-13. 1981.

18 ANDREASEN, J. O. et al. Replantation of 400 avulsed permanent incisors. 1. Diagnosis of healing complications. Endod Dent Traumat, v.11, n.2, p.51-8, 1995.

19 ANDREASEN, J. O. et al. Replantation of 400 avulsed permanent incisors. 2. Factors related to pulpal healing. Endod Dent Traumat, v.11, n.2, p.59-68, 1995.

20 ANDREASEN, J. O. et al. Replantation of 400 avulsed permanent incisors. 4. Factors related to periodontal ligament healing. Endod Dent Traumat, v.11, n.2, p.76-89, 1995.

21 BANKS, W.J. Histologia veterinária aplicada. 2.ed. São Paulo, Manole, 1992.

22 BARON, R. et al., Celular and molecular biology of the osteoclast. In: Noda, M. Celular and molecular biology of bone. San Diego, Academic Press, 1993. Cap. 14, p.445-95.

23 BARRETT, E. J.; KENNY, D. J. Avulsed permanent teeth: a review of the literature and treatment guidelines. Endod Dent Traumat, v.13, p.153-63, 1997.

24 BENATTI NETO, C. Tratamento de perfurações radiculares com pastas de hidróxido de cálcio e iodofórmio - Emprego de diferentes veículos - Estudo histológico em dentes de cães. 
Bauru, 1984. Tese (Doutorado) - Faculdade de Odontologia de Bauru, Universidade de São Paulo.

25 BJORVATN, K.; MASSLER, M. Effect of fluorides on root resorptions in replanted rat molars. Acta Odont Scand, v.29, n.1, p.17-29, 1971.

26 BJORVATN, K.; SELVIG, K. A.; KLINGE, B. Effect of the tetracycline and $\mathrm{SnF}_{2}$ on root resorption in replanted incisors in dogs. Scand J Dent Res, v.97, n.6, p.477-82, 1989.

27 BLOMLÖF, L.; LINDSKOG, S. Quality of periodontal healing II: dynamics of reparative cementum formation. Sweed Dent J, v.18, p.131-8, 1994.

28 BLOMLÖF, L. et al. Estorage of experimentally avulsed teeth in milk priot to replantation. J Dent Res, v.62, p. 912-6, 1983.

29 BREUIL, V. et al. Human osteoclast formation and activity in vitro: effects of alendronate. J Bone Min Res, v.13, p.1721-9, 1998.

30 BRYSON, E. C. et al. Effect of monocycline on healing of replanted dog teeth after expanded dry times. Dent Traumat, v.19, p.90-5, 2003.

31 BUTCHER, E. O.; VIDAIR, R. V. Periodontal fiber rettachment in replanted incisor of the monkey. J Dent Res, v.34, n.4, p.569-76, 1955.

32 CAFFESSE, R. G.; NASJLETI, C. E. CASTELLI, W. A. Long-term results after intentional tooth replantation in monkeys. Oral Surg, v.44, p.666-78, 1977.

33 COCCIA, C. T. A clinical investigation of root resorption rates in reimplanted young permanent incisors: a five-year study. J Endod, v.6, n.1, p.413-20, 1980.

34 COLUCCI, S. et al. Alendronate reduces adhesion of human osteoclastlike cells to bone and bone protein-coated surfaces. Calcif Tissue Int, v.63, p.230-5, 1998.

35 CONSOLARO, A. Reabsorções dentárias nas especialidades clínicas. Maringá, Dental Press, 2002.

36 CORREIA, V. F. P. et al. Análise da citotoxidade do alendronato de sódio sobre fibrosblastos do ligamento periodontal humano, Braz Oral Res, v.18, p.163, 2004. /Abstract n. Pb055/

37 CVEK, M. Treatment of non-vital permanent incisors with calcium hydroxide II. Effect on external root resorption in luxated teeth compared with the effect of root filling with gutta-percha. Odontol Rev, v.24, p.343-54, 1973. 
38 CVEK, M.; GRANATH, L.E.; HOLLENDER, L. Treatment of non-vital permanent incisors with calcium hydroxide III. Variation of occurance of ankylosis of reimplanted teeth with duration of extra-alveolar period and storage environment. Odontol Rev, v.25, p.43-56, 1974.

39 DEEB, E. Replantation of teeth: a recommended procedure. J South Calif Dent Assoc, v.39, n.10, p.24-9, 1971.

40 DIANGELIS, A. J.; BAKLAND, L.K. Lesões dentais traumáticas: conceitos atuais de tratamento. JADA - Brasil, v.2, p.7-20, 1999.

41 EBELESEDER, K.A. et al. A study of replantes permanent teeth in different age groups. Endod Dent Traumat, v.14, p.274-8, 1998.

42 EHNEVID, $\mathrm{H}$. et al. Tissue formation on cementum surfaces in vivo. Sweed Dent J, v.17, n.1/2, p.1-8, 1993.

43 ESCOBAR, C. A. B. Reimplante tardio de dentes incisivos imersos em solução de hipoclorito de sódio, tratados ou não com ácido cítrico. Estudo histológico em ratos. Araçatuba, 1997. 64p. Tese (Doutorado) - Faculdade de Odontologia de Araçatuba, Universidade Estadual Paulista "Júlio de Mesquita Filho".

44 ESTRELA, C.; PESCE, H. F. Chemical analysis of the liberation of calcium and hydroxyl ions from calcium tissue in the dog - Part I. Braz Dent J, v.7, n.1, p.41-6, 1996.

45 FILLIPI, A.; POHL, Y.; VON ARX, T. Treatment of replacement resorption with Emdogain ${ }^{\circledR}$ - preliminary results after 10 months. Dent Traumatol, v.17, n.3, p.134-8, 2001.

46 FINUCANE, D.; KINIRONS, M. J. External inflamatory and replacement resorption of luxated, and avulsed replanted permanent incisors: a review and case presentation. Dent Traumat, v.19, p.170-4, 2003.

47 FLEISCH, H. Bisphosphonates: a new class of drugs in deasese of the bone and calcium metabolism. Rec Res Cancer Res, v.116, p.1-28, 1989.

48 FLEISCH, H. Bisphosphonates. Farmacology and use in the treatment of tumor-induced hypercalcaemic and metastatic bone disease. Drugs, v.42, n.6, p.919-44, 1991.

49 FLEISCH, H. Bisphosphonate in osteoporosis: an introduction. Osteoporosis Int, v.3, p.3-5, 1993.

50 FUSS, Z.; TSESIS, I.; LIN, S. Root resorption - diagnosis, classification and treatment choices based on stimulation factors. Dent Traumat, v.19, p.175-82, 2003. 
51 GROPER, J. N.; BERNICK, S. Histological study of periodontium following replantation of the teeth in the dog. J Dent Child, v.37, p.25-35, 1970.

52 GROSSMAN, L. I.; MEIMAN, B. W. Solution of pulp tissue by chemical agents. J Amer Dent Ass, v.28, n.2, p.223-5, 1941.

53 HAMMARSTÖM, L.; BLOMLÖF, L.; LINDSKOG, S. Dynamics of dentoalveolar ankylosis and associated root resorption. Endod Dent Traumat, v.5, p.163-75, 1989.

54 HAMMARSTÖM, L.; LINDSKOG, S. General morphological aspects of resorption of teeth and alveolar bone. Int Endod J, v.18, p.93-108, 1985.

55 HAMMARSTÖM, L.; LINDSKOG, S. Factors regulating and modifying dental root resorption. Proc Finn Dent Soc, v.88, p.115-23, 1992. Supplement $1 / 2$.

56 HAMMARSTÖM, L. et al. Tooth avulsion and replantation: a review. Endod Dent Traumat, v.2, p.1-8, 1986.

57 HASSELGREN, G.; OLSSON, B.; CVEK, M. Effects of calcium hydroxide and solution hypoclorite on the dissolution of necrotic porcine muscle tissue. J Endod, v.14, n.3, p.125-7, 1988.

58 HEDRICH, H.J. History, strains and models. In: KRINKE, G.J. The laboratory rat. 1.ed. London, Academic Press, 2000. Cap.1, p.3-27.

59 HIDALGO, M. M. Estudo sobre o potencial imunogênico da dentina - contribuição para a etiopatogenia da reabsorção dentária. Bauru, 2001. 103p. Tese (Doutorado) - Faculdade de Odontologia de Bauru, Universidade de São Paulo.

60 HILTZ, J.; TROPE, M. Vitality of human lip fibroblasts in milk, Hank's balanced salt solution and Viaspan storage media. Endod Dent Traumat, v.47, p.69-7, 1991.

61 HUGHES, D. E. et al. Bisphosphonates promove apoptosis in murine osteoclasts in vitro and in vivo. J Bone Miner Res, v.10, p.1478-87, 1995.

62 IGARASHI, K. et al. Effects of bisphosphonates on alkaline phosphatase activity, mineralization, and prostaglandin $\mathrm{E}_{2}$ synthesis in the clonal osteoblast-like cell line MC3T3-E1. Prostaglandins, Leukotrienes and Essential Fatty Acids, v.56, p.121-5, 1997.

63 IQBAL; M. K.; BAMAAS, N. Effect of enamel matrix derivative $\left(\right.$ EMDOGAIN $\left.^{\circledR}\right)$ upon periodontal healing after replantation of 
permanent incisors in Beagle dogs. Dent Traumat, v.17, n.1, p.3645, 2001.

64 ISOLAN; T. M. P.; PERRI DE CARVALHO, A. C. Reimplante de dentes com canal e superfície radiculares tratados com solução alcalina tamponada. Estudo histológico em cães. Rev Odont UNESP, v.18, n.1/2, p. 91-100, 1989.

65 JÄRVINEN, S. Traumatic injuries to upper permanent incisors related to age and incisal overjet. Acta Odont Scand, v.37, p.335-38, 1979.

66 KANIS, J. A. et al. Rational for the use of alendronate in osteoporosis. Osteoporosis Int, v.5, p.1-13, 1995.

67 KANNO, C. M. Reimplante mediato de dentes tratados ou não com solução de hipoclorito de sódio a 1\%. Estudo histomorfológico em dentes de ratos. Araçatuba, 1996. 101p. Dissertação (Mestrado) - Faculdade de Odontologia de Araçatuba, Universidade Estadual Paulista "Júlio Mesquita Filho".

68 KELLER, R.K.; FLIESLER, S.J. Mechanism of aminophosphonate action: characterization of alendronate inhibition of the isoprenoid pathway. Biochem Biophys Res Commun, v.266, p.560-3, 1999.

69 KEUM, K-Y. et al. Effect of dexamethasone on root resorptionafter delayed replantation of rat tooth. J Endod, v.29, n.12, p.810-3, 2003.

$70 \mathrm{KUM}, \mathrm{K}-\mathrm{Y}$. et al. The inhibitory effect of alendronate and taurine on osteoclast defferentiationmediated by Porphyromonas gingivalis sonicates in vitro. J Endod, v.29, n.1, p.28-30, 2003.

71 LEKIC, P. et al. Relationship of clonogenic capacity to plating efficiency and vital dye staining of human periodontal ligament cells: implications for tooth replantation. J Periodont Res, v.31, p.294300, 1996.

72 LEONARDO, M. R.; ARAÚJO, C. H.; MENDES, A. J. D. Contribuição para o emprego de pastas à base de hidróxido de cálcio na obturação de canais radiculares - Estudo de propriedades físicas, químicas e biológicas. Parte I. Rev Fac Odontol Araçatuba, v.10, p.125-35, 1976. Supplement 1.

73 LEONARDO, M. R. et al. Histological of therapy using a calcium hydroxide dressing for teeth with incompletely formed apices and periapical lesion. J Endod, v.19, 1993. 
74 LEONARDO, M. R. et al. Avaliação dos tecidos apicais e periapicais de dentes de cães após biopulpectomias e utilização de diferentes curativos de demora. Rev Bras Odontol, v.53, p.14-9, 1996.

75 LEVIN, L. et al. Effect of topical alendronate on root resorption of dried reolanted dog teeth. Dent Traumat, v.17, n.3, p.120-6, 2001.

76 LIEWEHR, F. R. et al. Effect of bisphosphonates and gallium on dentin resorption in vitro. Endod Dent Traumat, v.11, n.1, p.20-6, 1995.

77 LIN, J. H. Bisphosphonates: a review of their pharmacokinetic properties. Bone, v.18, n.2, p.75-85, 1996.

78 LINDSKOG, S.; BLOMLÖF, L. Influence of osmolarity and composition of some storage media on human periodontal ligament cells. Acta Odont Scand, v.40, n.6, p.435-41, 1982.

79 LINDSKOG; S. et al. The role of the necrotic periodontal membrane in cementum resorption and ankylosis. Endod Dent Traumat, v.1, n.3, p. 96-101, 1985.

80 LINDSKOG, S. et al., Comparative effects of parathyroid hormone on osteoblasts and cementoblasts. J Clin Periodont, v.14, p.386-9, 1987.

81 LÖE, H.; WAERHAUG, J. Experimental replantation of teeth in dogs and monkeys. Arch. Oral Biol., v.3, n.3, p.176-84, 1961.

82 MASARACHIA, P. et al. Comparison of the distribution of ${ }^{3} \mathrm{H}$ alendronate and ${ }^{3} \mathrm{H}$-etiodrate in rat and mouse bone. Bone, v.19, p.281-90, 1996.

83 MINKIN, C.; JENNINGS, J. M. Carbonic anhydrase and bone remodeling: sulfonamide inhibition of bone resorption in organ culture. Science, v.176, p.1031-3, 1972.

84 MORETTON, T. R. et al. Tissue reactions after subcutaneous and intraosseous implantation of mineral trioxide aggregate and ethoxybenzoic acid cement. J Biom Mat Res, v.52, n.3, p. 528-33, 2000.

85 MORI, G. G. Estudo microscópico do efeito do tratamento da superfície radicular com acetazolamida em dentes de ratos avulsionados e reimplantados. Bauru, 2002. 96p. Tese (Mestrrado) - Faculdade de Odontologia de Bauru, Universidade de São Paulo.

$86 \mathrm{MORI}, \mathrm{G}$. G. et al. Evaluation of the dffusion capacity of the solution of alendronate through the dentinal tubules. Dent Traumat, 2005. /in press/ 
87 MURAD, R. Estudo microscópico sobre a influência da raspagem da membrana periodontal elou remoção da polpa e obturação do canal com hidróxido de cálcio em reimplantes dentais em cães. Araçatuba, 1982. 41p. Dissertação (Mestrado) - Faculdade de Odontologia de Araçatuba, Universidade Estadual Paulista "Júlio Mesquita Filho".

88 NAKAMURA, $\mathrm{H}$. et al. The solvent action of sodium hypoclorite on bovine tendon collagen, bovine pulp and bovine gengival. Oral Surg, v.60, n.3, p.322-6, 1985.

89 NAKANE, S.; KAMEYAMA, Y. Root resoption caused by mechanical injury of the periodontal soft tissues in rats. J Period Res, v.22, n.5, p.390-5, 1987.

90 NE, R. F.; WITHERSPOON, D. E.; GUTMANN, J. L. Tooth resorption. Quintessence Int, v.30, p.9-25, 1999.

91 NEVINS, A. J. et al. Replantation of enzimatically treated teeth in monkeys. Part I. Oral Surg, v.50, n.3, p.277-81, 1980.

92 NISHIOKA, M. et al. Tooth replantation in germ-free and conventional rats. Endod Dent Traumat, v.14, p.163-73, 1998.

93 OIKARINEN, K.; KASSILA, O. Causes and types of traumatic tooth injuries treated in a public dental health clinic. Endod Dent Traumat, v.3, p.172-7, 1987.

94 OKAMOTO, T.; OKAMOTO, R. Interferência da imobilização sobre o processo de reparação após o reimplante imediato de incisivo superior de rato. Estudo histomorfológico. Rev Odont UNESP, v.24, n.1, p.87-98, 1995.

95 OKAMOTO, T.; RUSSO, M. C. Wound healing following tooth extraction. Hitochemical study in rats. Rev Fac Odont Araçatuba, v.2, n.2, p.153-60, 1973.

96 OKAMOTO, T. et al. Reimplante imediato de incisivo superior de rato após remoção do ligamento periodontal cementário e alveolar. Rev Bras Odont, v.52, n.6, p.22-6, 1995.

97 OSWALD, R. J.; HARRINGTON, G. W.; VAN HASSEL, H. J. A postreplantation evaluation of air-dried and saliva stored avulsed teeth. J Endod, v.6, p.546-51, 1980.

98 PANZARINI, S. R. Reimplante dental tardio após tratamento da superfície radicular com hipoclorito de sódio a 1\%, vitamina C e fluoreto de sódio a $2 \%$. Análise microscópica em dentes de ratos. Araçatuba, 2001. 238p. Tese (Doutorado) - Faculdade de 
Odontologia de Araçatuba, Universidade Estadual Paulista "Júlio de Mesquita Filho".

99 PATIL, S.; DUMSHA, T. C.; SYDISKIS, R. J. Determining periodontal ligament (PDL) cell vitality from exarticulated teeth stored in saline or milk using fluorescein diacetate. Int Endod J, v.27, p.1-5, 1994.

100 PERCINOTO, C. Influência da imersão em solução de hipoclorito de sódio em reimplantes de dentes com canais obturados com hidróxido de cálcio após a extração. Estudo histológico em cães. Bauru, 1986. 106p. Tese (Doutorado) - Faculdade de Odontologia de Bauru, Universidade de São Paulo.

101 PETTIETTE, M. et al. Periodontal healing of extracted dogs' teeth airdried for extended periods and soaked in various media. Endod Dent Traumat, v.13, p.113-8, 1997.

102 PIERCE, A. Experimental basis for the arrengement of dental resorption. Endod Dent Traumat, v.5, p.255-65, 1989.

103 POI, W. R. et al. Influência do volume do hipoclorito de sódio a $1 \%$ na remoção do ligamento periodontal necrosado. Rev Assoc Paul Cirur Dent, v.55, n.4, p.286-90, 2001.

104 POLSON, A. M.; PROYE, M. Effect of root surface alterations on periodontal healing II. Citric acid treatment of the desnude root. J Clin Period, v.9, n.6, p.441-54, 1982.

105 RENON, M. A. Reimplante de dentes tratados com hipoclorito de sódio com e sem remoção mecânica do ligamento periodontal: estudo microscópico em ratos. Araçatuba, 1999. 252p. Tese (Doutorado) - Faculdade de Odontologia de Araçatuba, Universidade Estadual Paulista "Júlio de Mesquita Filho".

106 RODAN, G. A. Mechanisms of action of bisphosphonates. Annu Rev Pharmacol Toxicol, v. 38, p. 375-88, 1998.

107 RODAN, G. A.; MARTIN, T. J. Role of the osteoblasts in hormonal control of bone resorption - a hypothesis. Calcif Tissue Res, v.33, p.349-51, 1981.

108 SAE-LIM, V. et al. The effect of systemic tetracycline on resorption of dried replanted dogs' teeth. Endod Dent Traumat, v.14, n.3, p.12732, 1998.

109 SAFAVI, K.; NICHOLS, F. C. Effect of calcium hydroxide on bacterial lipopolysaccaride. J Endod, v.19, n.2, p.76-8, 1993.

110 SAHNI, M. et al. Bisphosphonates act on rat bone resorption through the mediation of osteoblasts. J Clin Invest, v.91, p.2004-11, 1993. 
111 SATO, M. et al. Bisphosphonate action: alendronate localization in rat bone and effects on osteoclast ultrastruture. J Clin Invest, v.88, p.2095-105, 1991.

112 SCHOUR, I; MASSLER, M. The teeth. In: FARRIS, E.J.; GRIFFITH, J.K. The rat in laboratory investigation. 2.ed. New York, Hafner Publishing Co., 1967. Cap.6, p.104-65.

113 SELBY, P. Alendronate treatment for osteoporosis: a review of the clinical evidendce. Osteoporosis Int, v.6, p.419-26, 1996.

114 SELVIG, K. A. et al. Effect of stannous fluoride and tetracycline on periodontal repair after delayed tooth replantation in dogs. Scand J Dent Res, v.100, p.200-3, 1992.

115 SHULMAN, L. B.; GEDALIA, I.; FEINGOLD, R. M. Fluoride concentration in root surfaces and alveolar bone of fluorideimmersed monkey incisors three weeks after replantation. J Dent Res, v.52, n.6, p.1314-6, 1973.

116 SHULMAN, L. B.; KALIS, P.; GOLDHABER, P. Fluoride inhibition of tooth replant root resorption in Cebus monkeys. J Oral Ther Pharmacol, v.4, p.331-7, 1968.

117 SIQUEIRA JR, J. F.; LOPES, H. P. Mechanism of antimicrobial activity of calcium hydroxide. A clinical review. Int Endod J, v.32, p.361-9, 1999.

118 SJÖGREN, V. et al. The antimicrobial effect to calcium hydroxide as a short-term intracanal Calasept dressing. Int Endod J, v.24, n.3, p.119-25, 1991.

119 SONODA, C. K. Reimplante mediato de dentes com a superfície radicular tratada com solução de hipoclorito de sódio a $2 \%$ e solução de fluoreto de sódio a $2 \%$. Estudo histomorfológico em cães. Araçatuba, 1997. 109p. Tese (Doutorado) - Faculdade de Odontologia de Araçatuba, Universidade Estadual Paulista "Júlio de Mesquita Filho".

120 SONODA, C. K. et al. Reimplante imediato de dentes após o tratamento da raiz com solução de hipoclorito de sódio a 1\%, 2,5\%, 5\% e 10\%. Rev Bras Odont, v.57, n.5, p.293-6, 2000.

121 SOMMERCORN, L. M. et al. Effect of alendronate on immature human dental root explants. J Endod, v.26, n.3, p.133-7, 2000.

122 TRONSTAD, L. Root resorption - etiology, terminology and clinical manifestations. Endod Dent Traumat, v.4, n.6, p.241-52, 1988. 
123 TRONSTAD, L. et al. PH changes in dental tissues after root canal filling with calcium hydroxide. J Endod, v.7, p.17-21, 1981.

124 TROPE, M. Clinical management of the avulsed tooth: present strategies and future directions. Dent Traumat, v.18, p.1-11, 2002.

125 TROPE, M. et al. Effect of differents endodontic treatment protocols on periodontal repair and root resorption of replanted dog teeth. J Endod, v.18, n.10, p.492-6, 1992.

126 TROPE, M. et al. Short vs. Long-term calcium hydroxide treatment on inflamatory resorption or occurrence of ankylosis in mature traumatized teeth: a review. Endod Dent Traumat, v.11, n.3, p.1248, 1995.

127 TSUCHIMOTO, M. et al. Alendronate modulates osteogenis of human osteoblastic cells in vitro. Jpn J Pharmacol, v.66, p.25-33, 1994.

128 VITTE, C.; FLEISCH, H.; Guenter, H.L. Bisphosphonates induce osteoblasts to secrete an inhibitor of osteoclast-mediated resorption. Endocrinology, v.137, p.2324-33, 1996.

129 WIKESJÖ, U. M. E. et al. Periodontal repair in dogs: effect of root surface treatment with stannous fluoride or citric acid on root resoption. J Period, v.62, n.3, p.180-4, 1991. 
Abstract 


\section{ABSTRACT \\ EVALUATION OF THE TOPICAL EFFECT OF ALENDRONATE ON THE ROOT SURFACE OF EXTRACTED AND REPLANTED TEETH. MICROSCOPIC ANALYSIS ON RATS' TEETH}

The treatment of choice for dental avulsion is replantation. The ideal replantation should be realized as quickly as possible, or at least, the avulsed tooth should be kept in an adequate solution to preserve the periodontal tissue attached to the root. If that is not possible, treatment of the radicular surface should be done in order to prevent radicular resorption. The purpose of this study was to test sodium alendronate as a substance for topic treatment of the radicular surface of avulsed teeth in an attempt to avoid the occurrence of dental resorptions. Fifty-four rat maxillary right central incisors were extracted and replanted, and further divided into: Group I extra-alveolar period of 15 minutes, intracanal dressing with calcium hydroxide $\left(\mathrm{CALEN}^{\circledR}\right)$ and replantation; Groups II and III - extra-alveolar periods of 30 and 60 minutes respectively, immersion in $1 \%$ sodium hypochlorite for 30 minutes for removal of the periodontal ligament, washing in saline solution for 5 minutes and treatment of the radicular surface with 3,2 $\mathrm{mg} / \mathrm{l}$ sodium alendronate solution for 10 minutes. Intracanal dressing with calcium hydroxide and replantation followed. At 15, 60 and 90 days postreimplantation, the animals were killed, samples obtained and processed for microscopic analysis. The results indicated that sodium alendronate was able to reduce the incidence of radicular resorption but not of dental ankylosis. No significant differences were observed regarding variations in the extraalveolar periods among the groups. 